Fall 1939

\title{
1939 Cedrus Yearbook
}

\section{Cedarville College}

Follow this and additional works at: https://digitalcommons.cedarville.edu/yearbooks

Part of the Higher Education Commons, Organizational Communication Commons, and the Public Relations and Advertising Commons

\section{Recommended Citation}

Cedarville College, "1939 Cedrus Yearbook" (1939). Yearbooks. 70.

https://digitalcommons.cedarville.edu/yearbooks/70

This Book is brought to you for free and open access by DigitalCommons@Cedarville, a service of the Centennial Library. It has been accepted for inclusion in Yearbooks by an authorized administrator of DigitalCommons@Cedarville. For more information, please contact digitalcommons@cedarville.edu. 


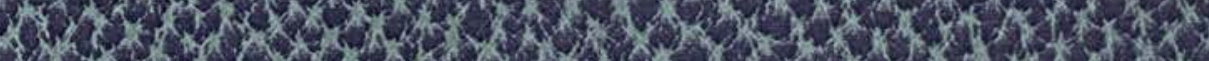

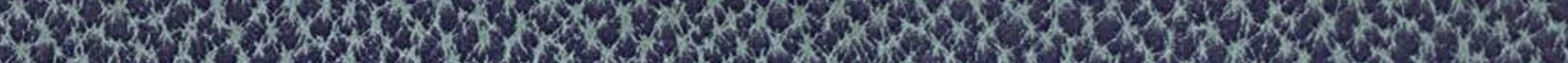

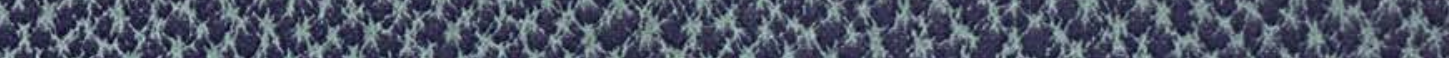

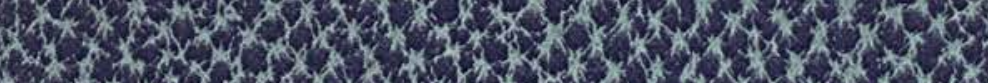
(1) $x+2 x$

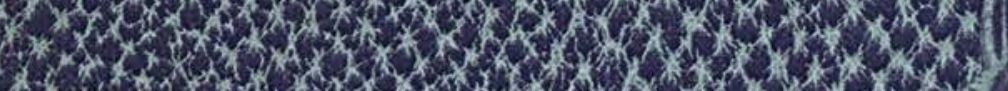

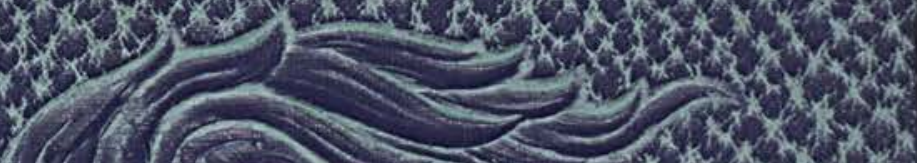

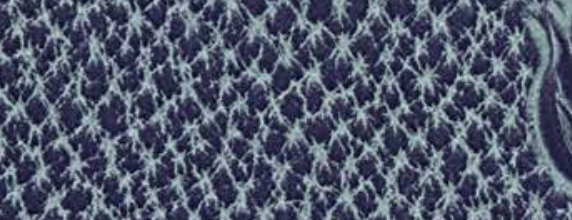

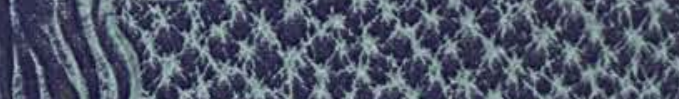
(x)

\section{s.}

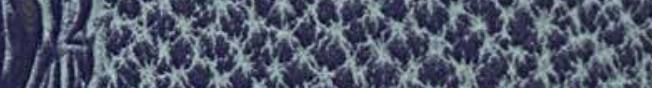

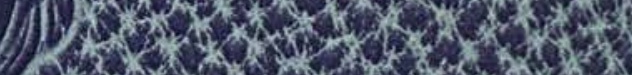
50 m.

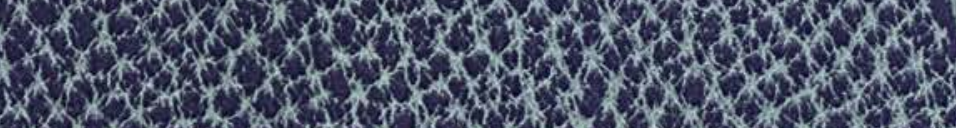
IIIII, $x$. 00000

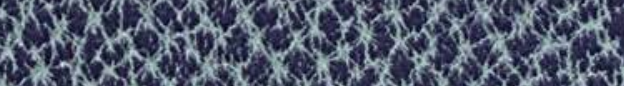

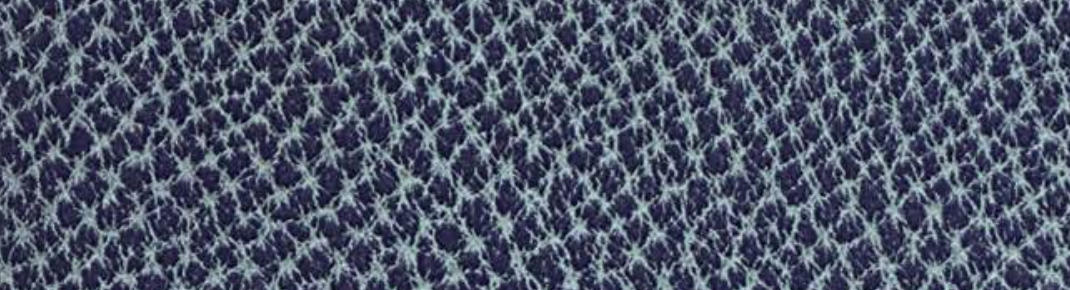

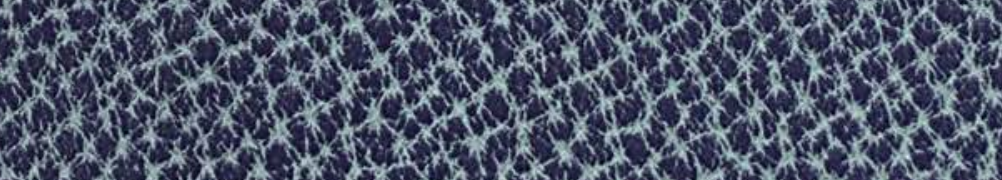

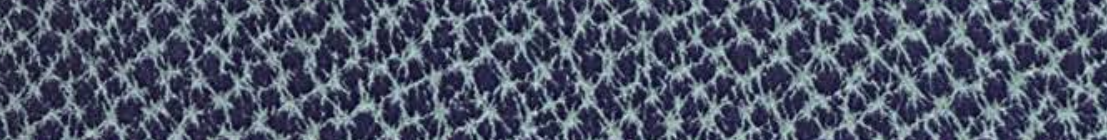

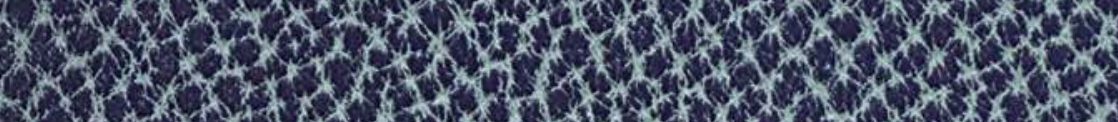
6. 10.0 . 6.t.

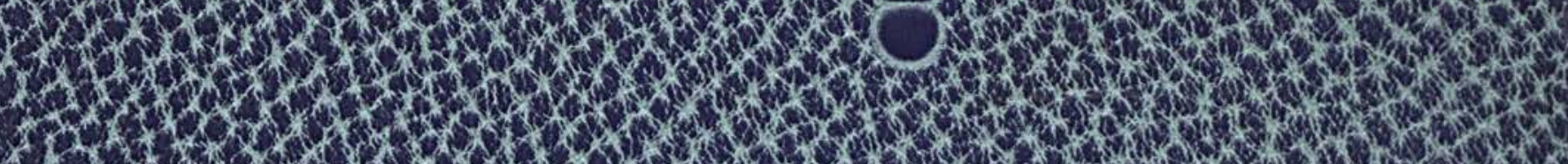

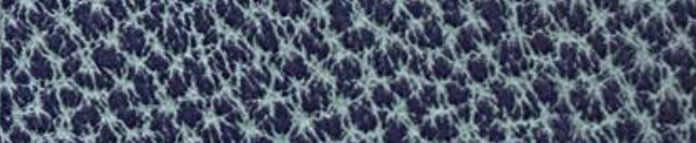
H.t.m. 7 . 1 .

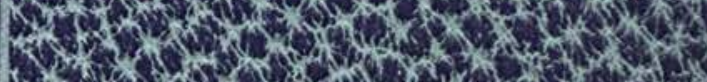

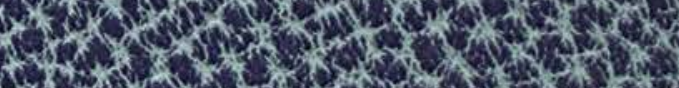

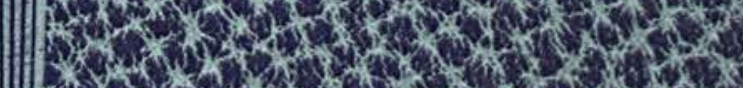




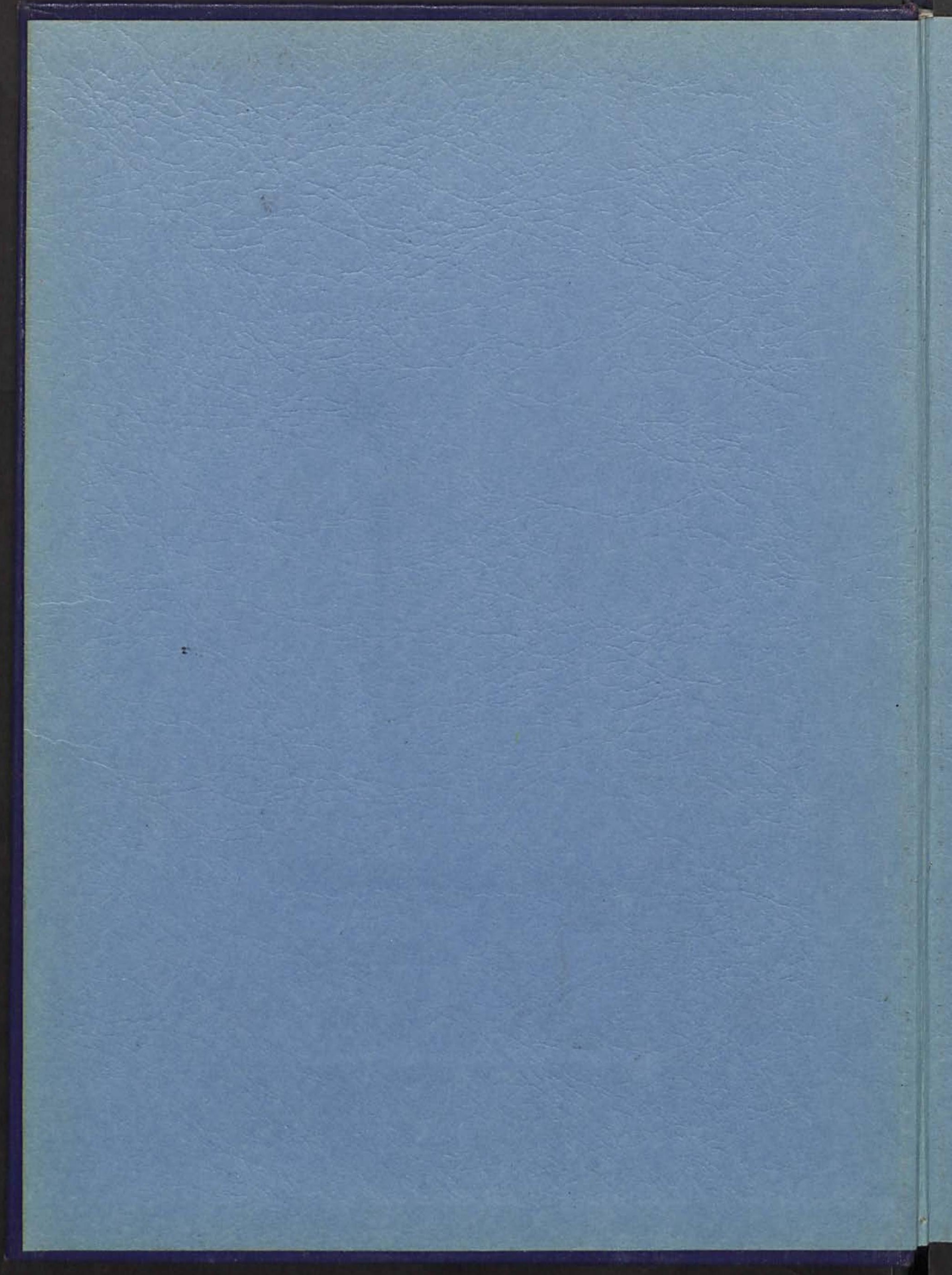




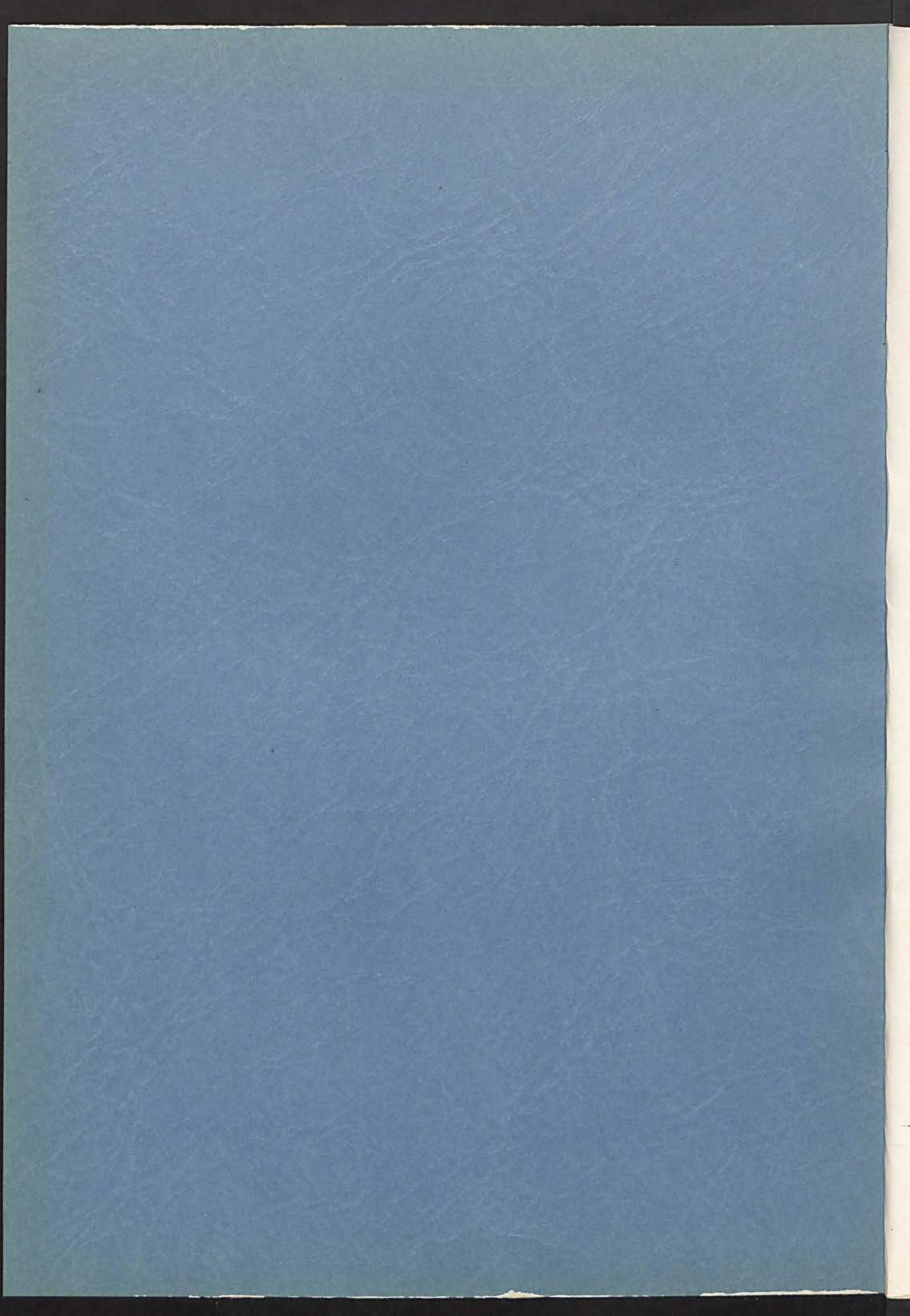




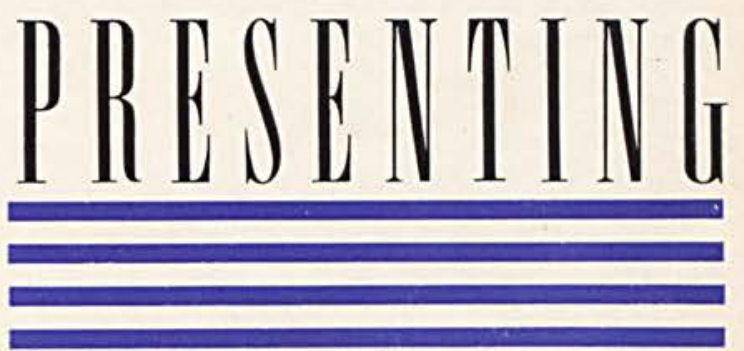




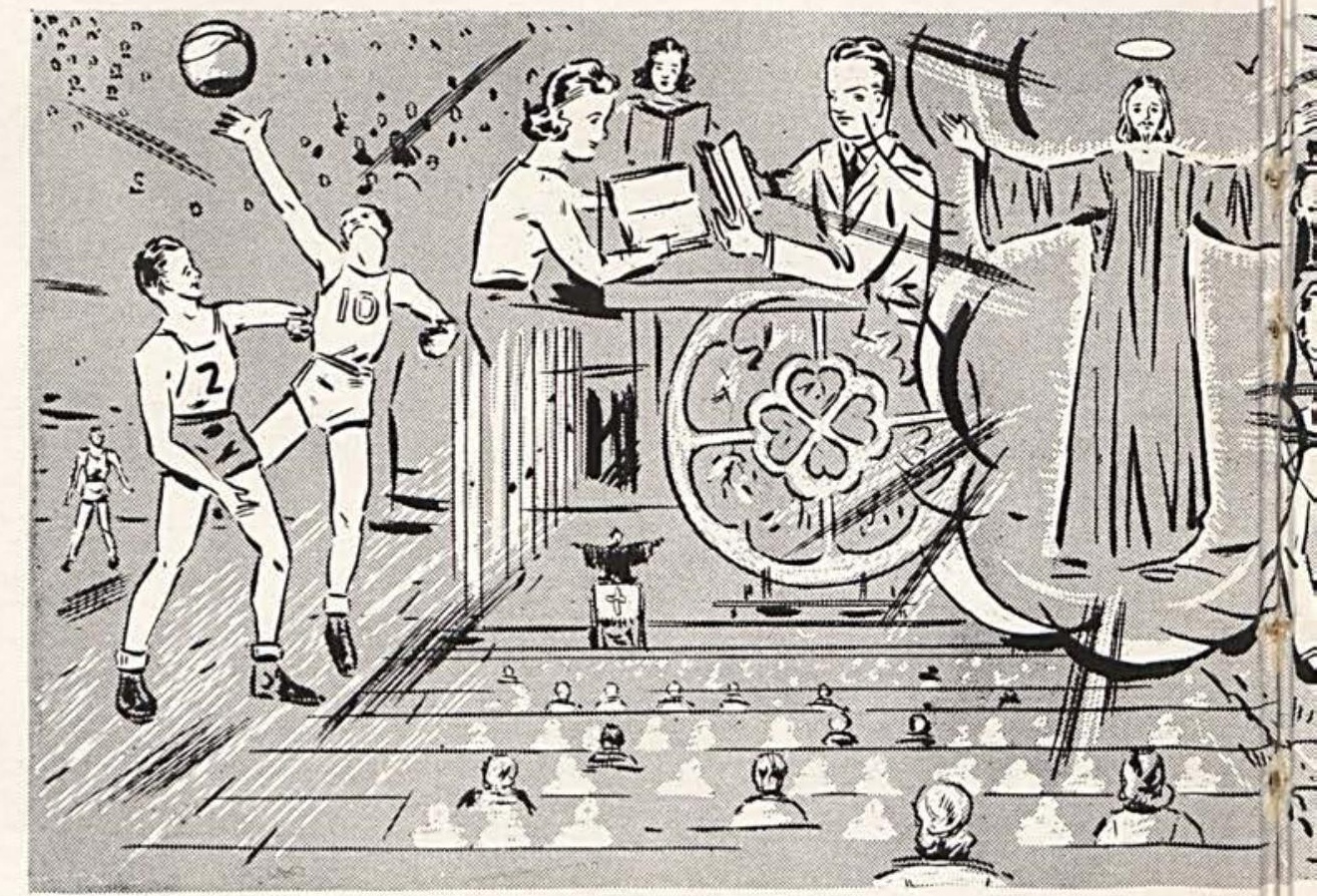

\section{THE}
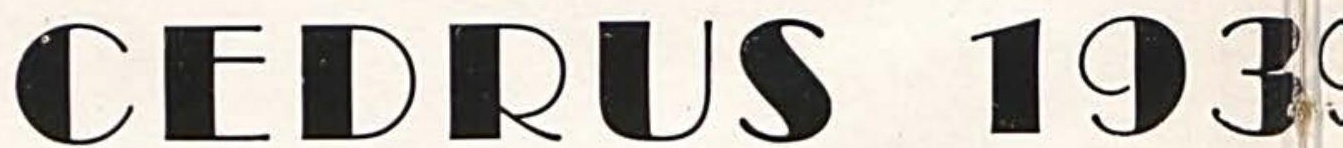

LEARNING TO LIVE AT CEDARVILLE COLLEGE BY:D 


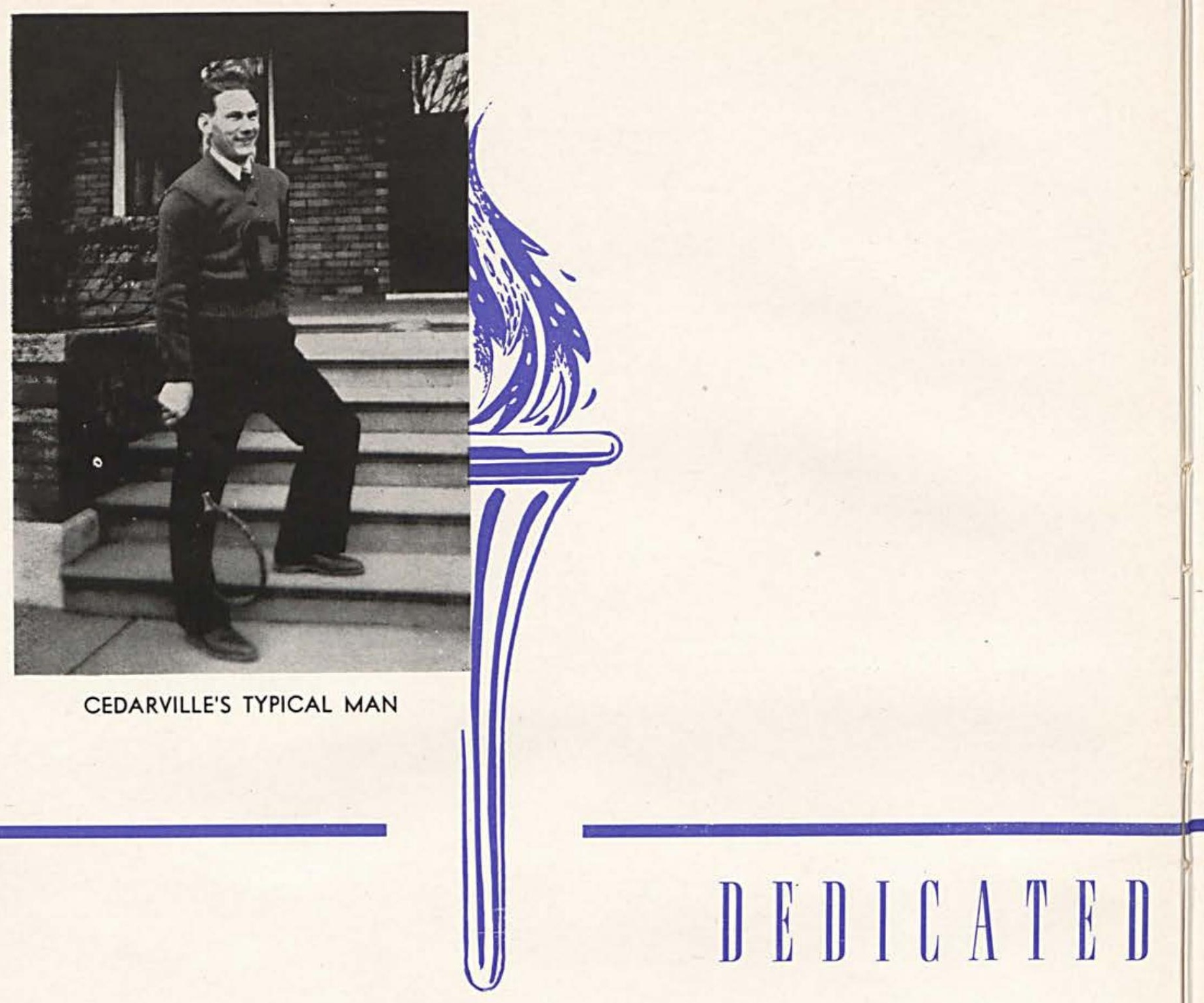

To the fellows of Cedarville College we dedicate this book. Cecil Thomas has been chosen by the student body as the man who best represents the abilities and characteristics of a real Cedarville man. He is a scholar, graduating with magna cum laude; an athlete, receiving letters in basketball and baseball throughout his four years of college life; and last and most important a leader and friend of everyone. Cecil has been the spark of life in many college parties and his jovial "greetings" is music to the ears of all who know him. 


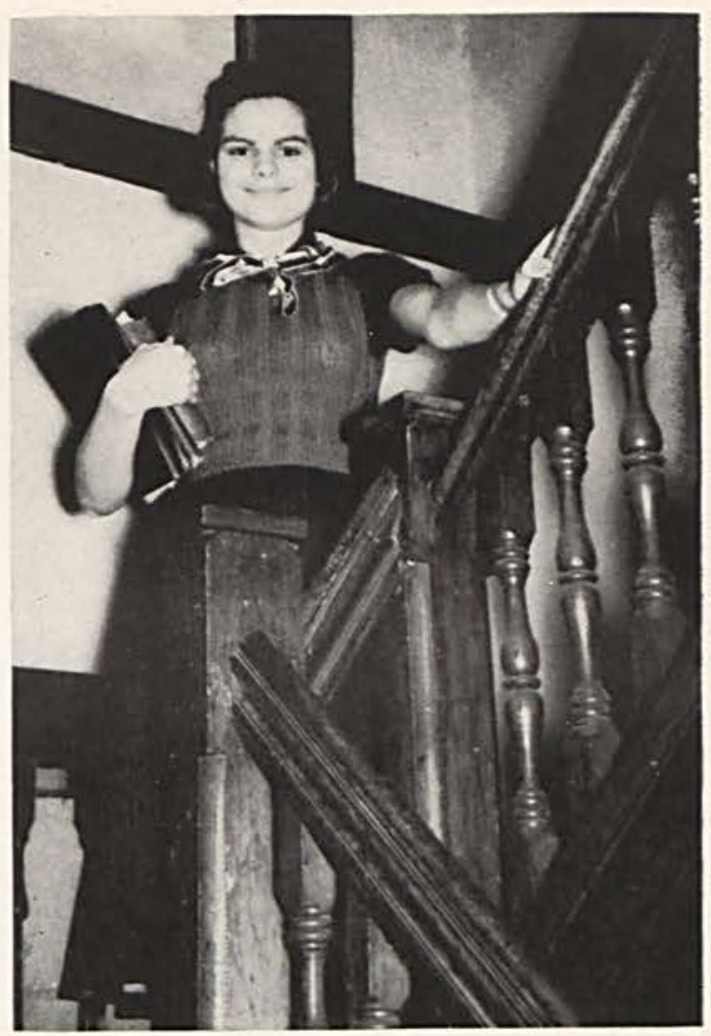

CEDARVILLE'S TYPICAL GIRL

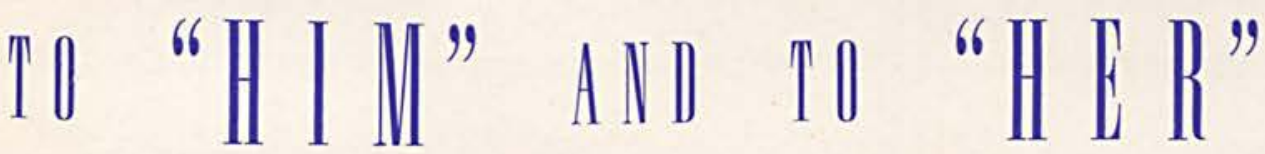

To the girls of Cedarville College we dedicate this book. Elisabeth "Pud" Anderson has been rightfully named the girl of Cedarville College who strives and most nearly attains the best and finest in womanhood; she is truly Cedarville's typical girl. "Puddy", though only a sophomore, has established a reputation as a scholar and an athlete. She is a most popular friend of a very critical set, the college men. "Puddy" is very active in local church activities and takes a real interest in everything that is good. As a real Cedarville girl she is most appropriately described as "class deluxe."

The Editor. 


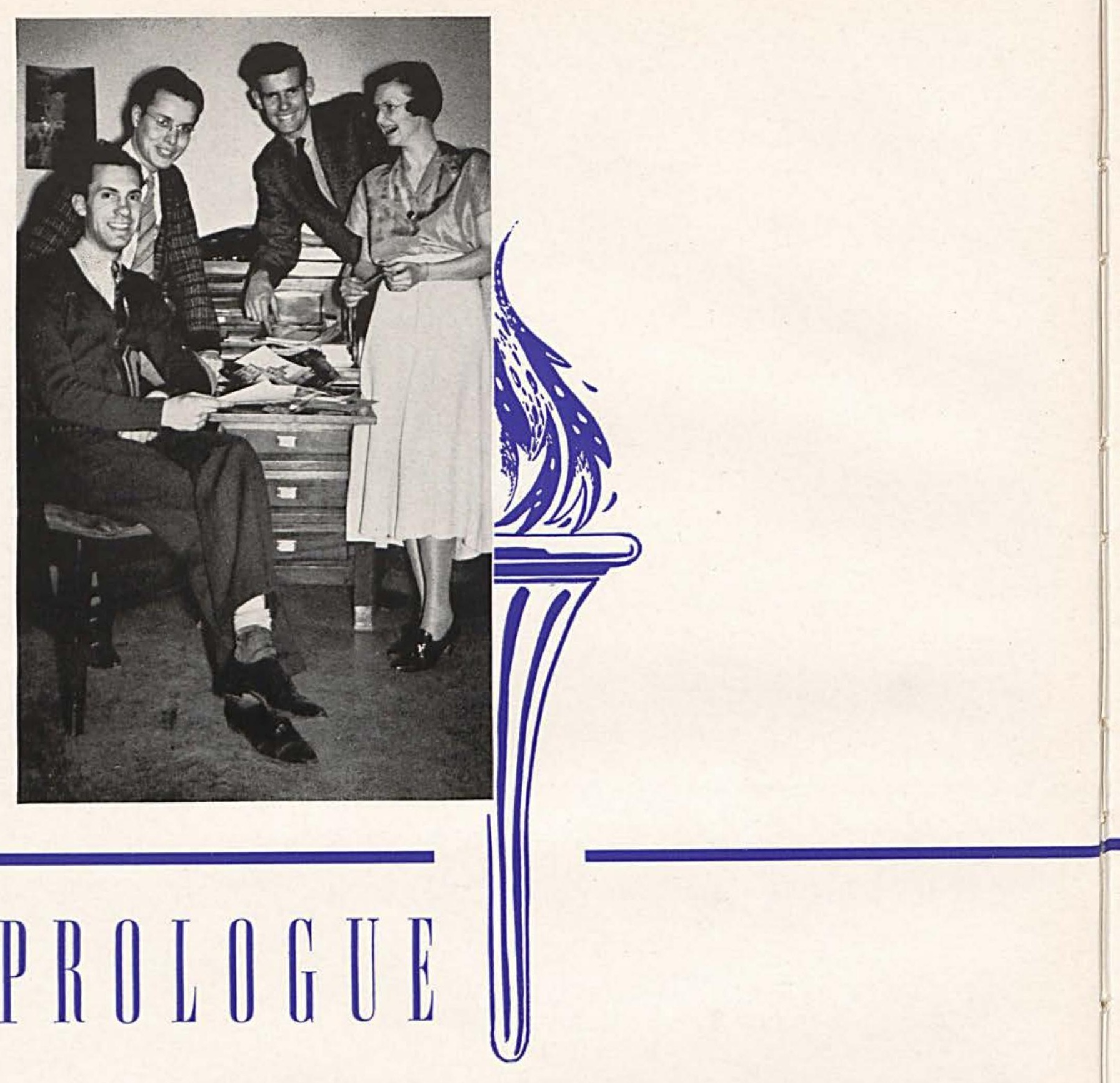




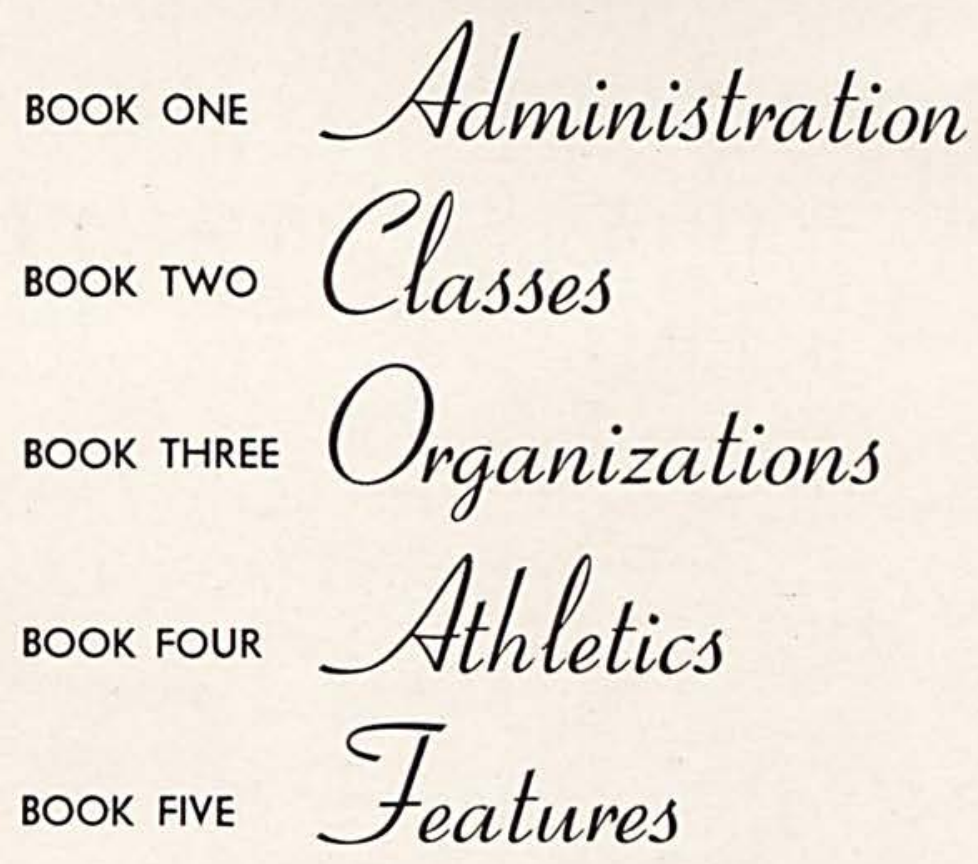


There has come to us through ages of progress and development, from a past so remote we can barely guess at its age, an heritage of information which must continuously be correlated with the new. Instruction in that which is both old and new, in that which is neither old nor new, today must be offered to those who seek, that they may judiciously select and prepare for the tomorrow that awaits.

ERNEST GIBSON, Faculty Adviser of Cedrus.

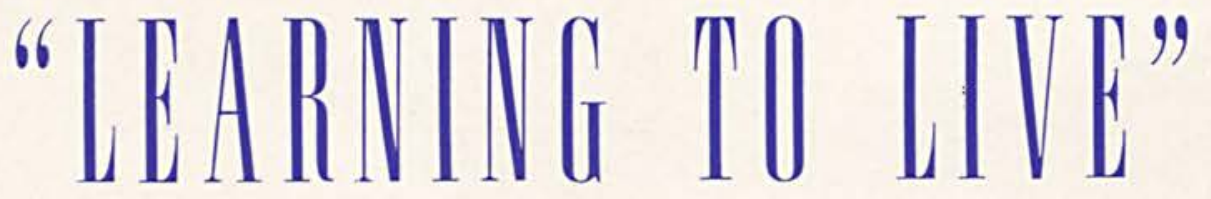




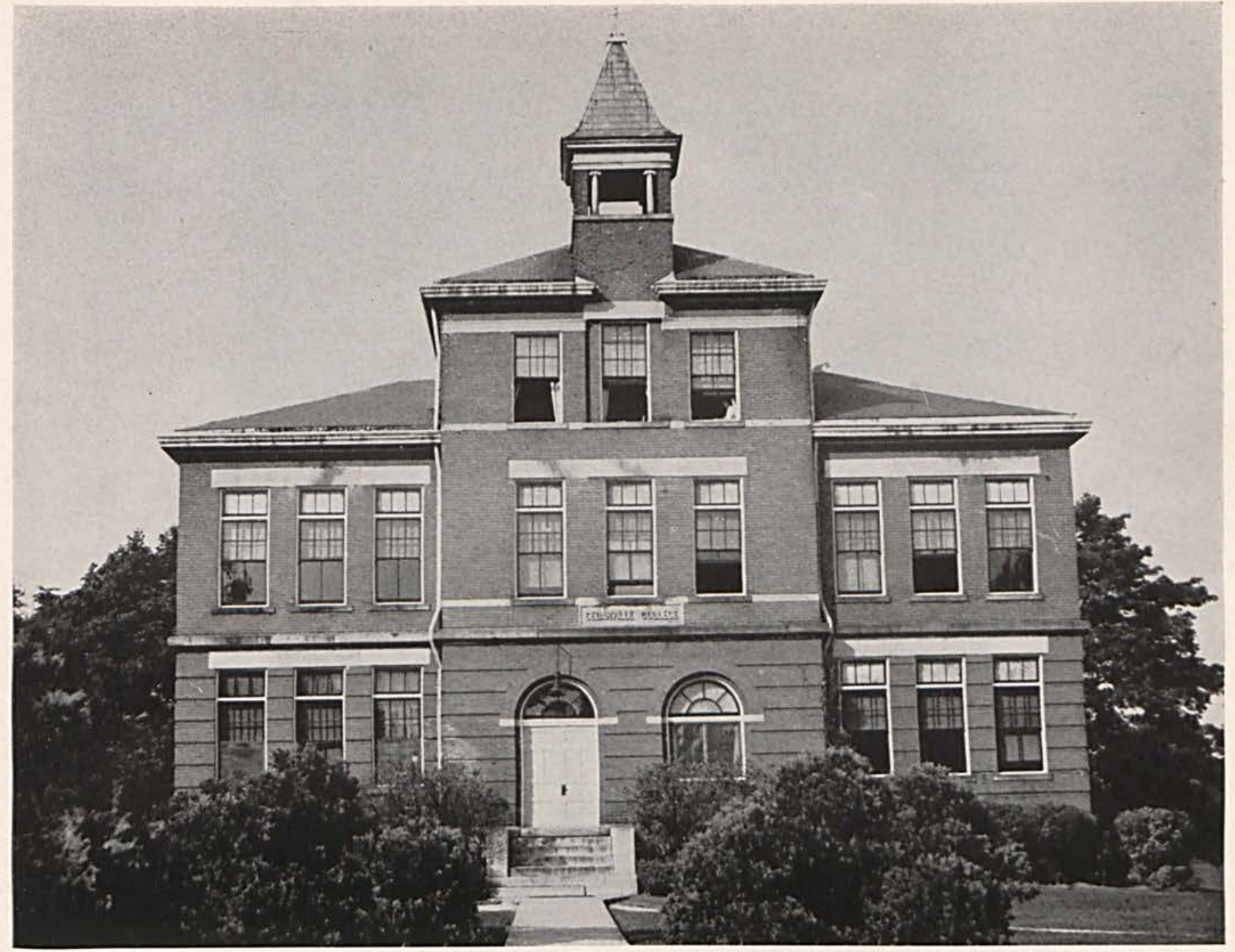

\section{CEARBIIE AUMINISTRATURS}

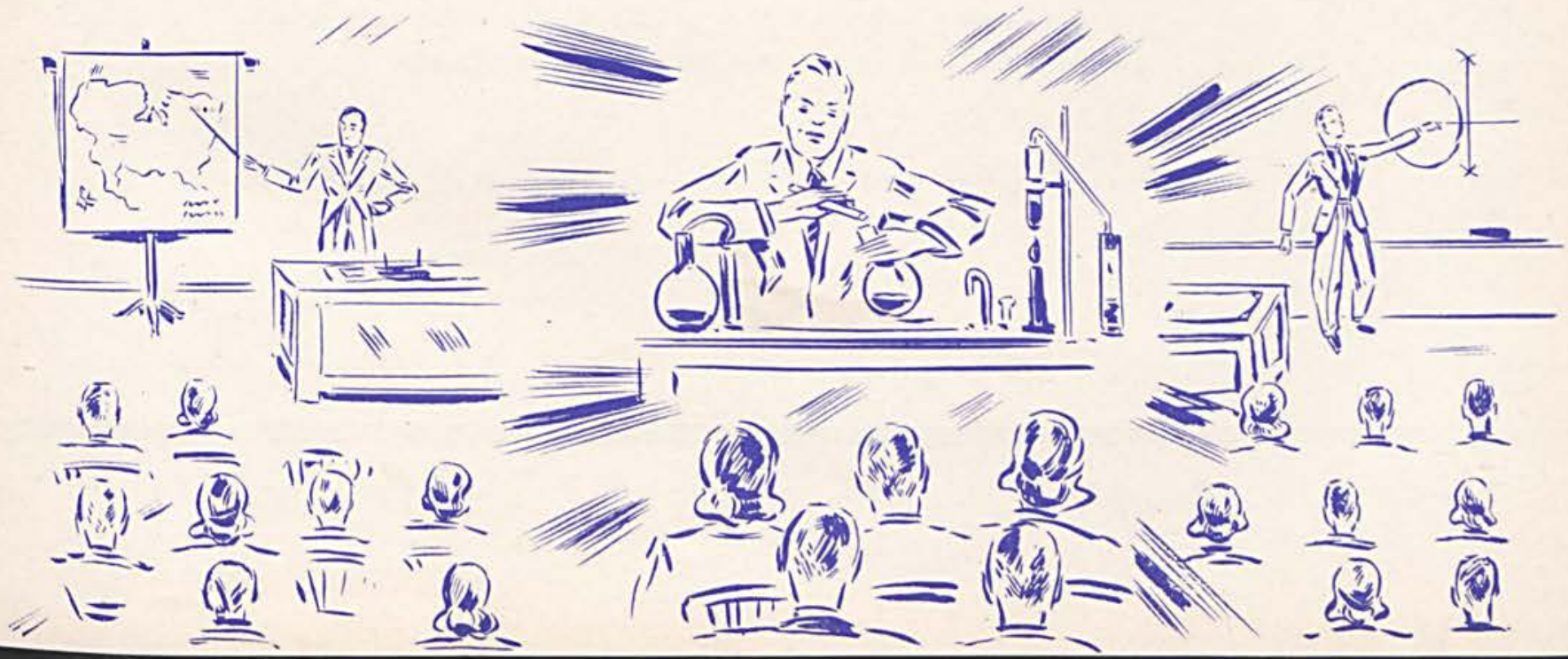




\section{BOARI OP TRUSTHES}

Students of Cedarville College are indebted to the Board of Trustees for the work that they have done and are doing to make C. C. a more complete school by enlarging the curriculum. In addition to the donation of their time, they also give freely material aid.

The president of the board is W. Clyde Howard of Chicago. Annual meetings are held on the Thursday of Commencement week. Semiannual meetings are held on the first Friday of December for the purpose of electing faculty members. At the present time there is a special Commission under the Chairmanship of Rev. D. L. Guthrie to make plans for the future welfare of Cedarville College.

- JANE FRAME.

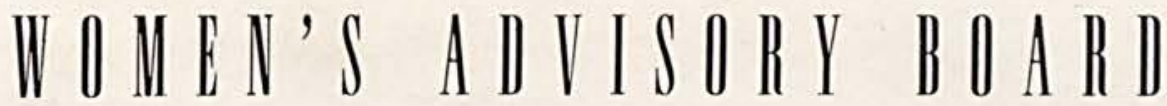

The Women's Advisory Board plays a very important role in the life of the college. At the Alumni and Homecoming Banquets it is always busy preparing and serving the meals. The profits from these banquets are used for the good of the college.

It has helped in redecorating the college administration building, has equipped the stage in the gymnasium, and has added to its supplies in kitchen utensils. It also purchased equipment for the college boarding club.

The members are chosen from the alumni and wives of the faculty. Mrs. W. R. McChesney is president of the organization.

-BETTY ROWE. 


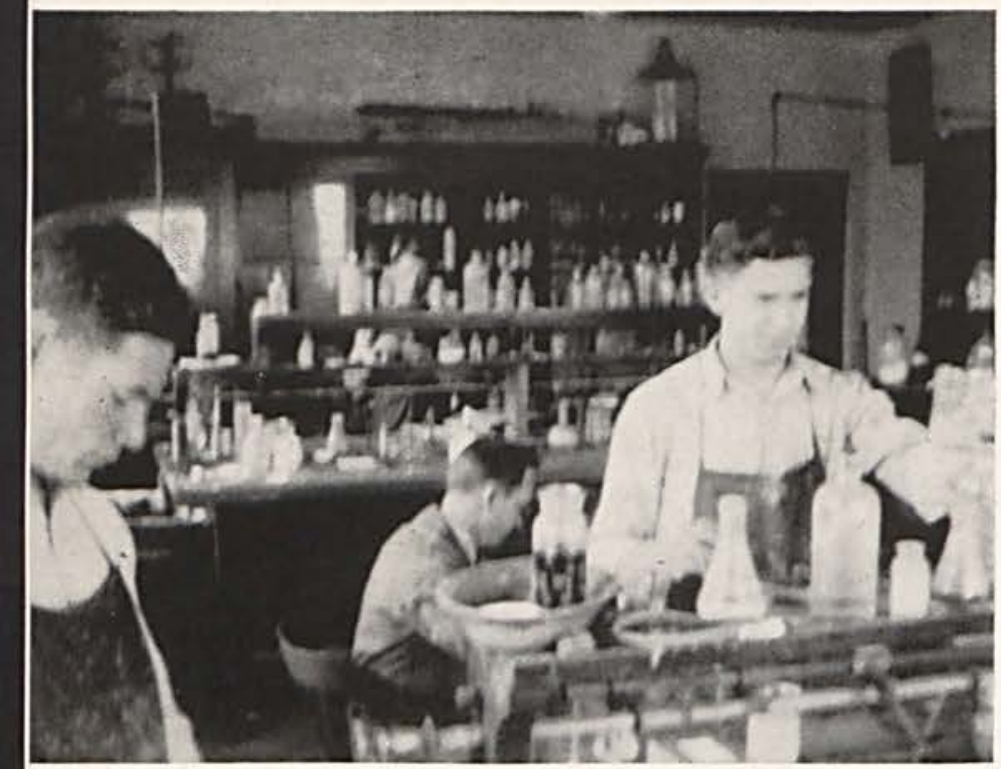

Priting

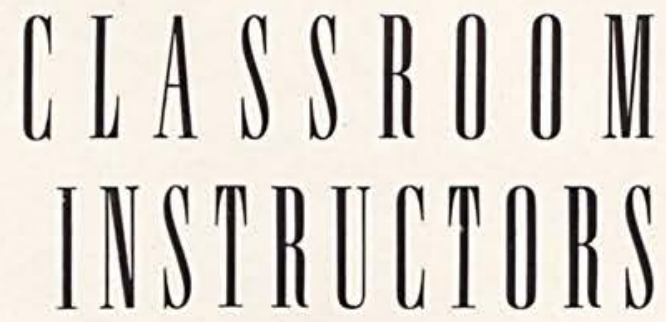

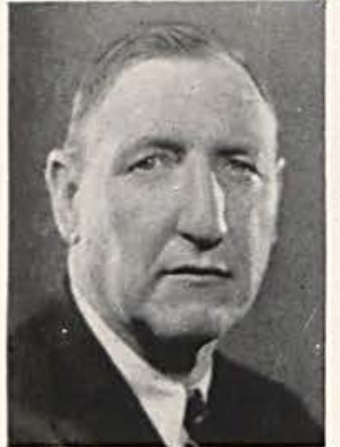

1. A. JURK.IT. Professor of History and Language A. I:. Franklin College
Li.. D. Franklin College

I. M. Wittenberg College
The students of Cedarville College are indeed fortunate in having a faculty who are not only well trained in each of their respective fields but are also vitally interested in the success and personal welfare of every student they contact. No student could ask for better cooperation in any institution than is received from these faithful servants. They are performing a real service and the influence they have on every Cedarville student has been and will continue to be felt in many parts of the country and in almost all walks of life.

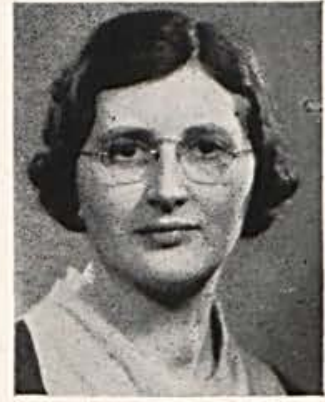

EMM. FORCE, Professor of Elementary Ed. B. S. Ohio State University sity

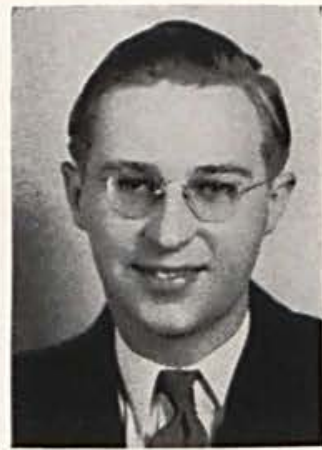

LESLIE MILLER, Professor of Mathematics and Physics

Director of Physical Edu.

cation

1. I. Rio Grande

A. II. Ohio University

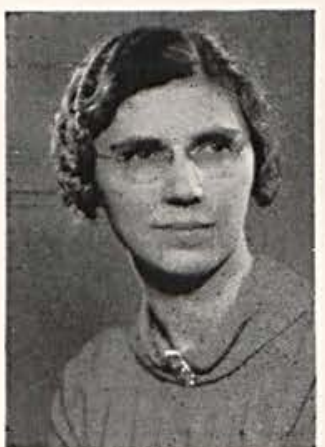

GIENNA BASORE, Secretary and Assistant Regis. trar

B. O. Ohio Northern University

1. I. Cedarville College 
Rev. W, R. McChesney, president since 1919, received his training in Franklin, Muskingum, and Tarkio Colleges. He taught Latin, Greek, History, Psychology, and Philosophy in Franklin, Wooster, and Cedarville Colleges. He has been on the Cedarville faculty since 1894 and served as secretary of the faculty until 1909 when he was made vice president. He served in this capacity for four years and then was made dean 1913-1915. Dr. McChesney has been an invaluable guide and leader for the youth of Cedarville College and has exerted an influence on their lives that will help them solve many difficult problems in the future.

A vital assistant in the daily life of the president is his secretary, Miss Glenna Basore. Miss Basore was gradu. ated from the Hawke's School of Expression, Cincinnati and received additional training at Ohio Northern University and Cedarville College. Besides acting as secretary Miss Basore serves in the capacity of Bureau of Information not only for the president and faculty but for all the students as well. Miss Basore is noted for her pleasant disposition and her willingness to help anyone at any time.

Prof. A. J. Hostetler received his B.S. degree at Ohio Northern University and finished his graduate work ot Wittenberg College. Mr. Hostetler has served in various phases of the educational field from teacher to high school principal, county Superintendent, director of County Normal, and head of the Education Department of Cedarville College. This department has been most successful in securing positions for its graduates and under the supervision of $\mathrm{Mr}$. Hostetler has established one of the most efficient placement bureaus in the state of Ohio.

Prof. Ernest R. Gibson graduated from Cedarville College in 1928. He received his graduate work at Ohio State University and has been on the college faculty for the past two years. In these two short years he has become one of the most popular of all faculty members in the classroom as well as in the social life of the college. Mr. Gibson is faculty adviser for the Cedrus as well as for the Delta Kappa Sigma Fraternity.

Prof. C. W. Steele received his training at Indiana State Normal School, Indiana Teachers College, and North western University. In addition to teaching in rural, grade, and high schools. Mr. Steele has served on the faculty at

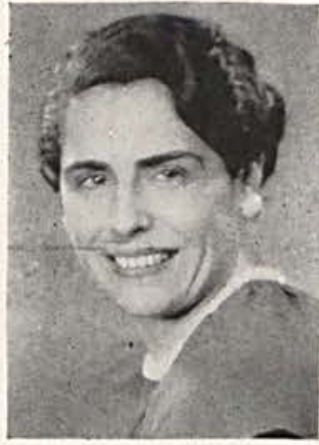

MARGUERITE A ULT Professor of French and Public Speaking

B. S. Bowling Green State College

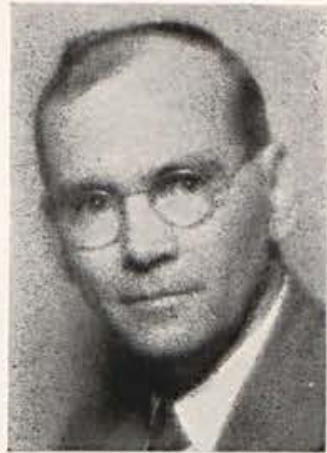

A. J. HOSTETLER, Reg: istrar and Director of Fducation

B. S. Ohio Northern Uni

A. M. Wittenberg College

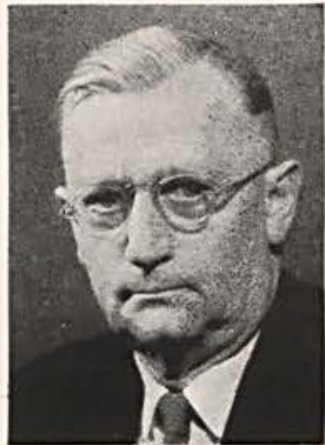

C. W. STEELE, Dean of Met

Professor of Social Science l. B. Indiana 'Tcacher's

II. S. Northwestern Iniversity

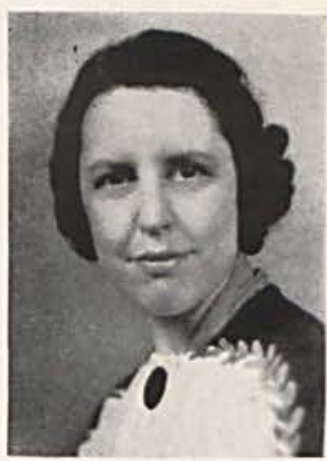

ELOISE KI.ING, Professor of Elementary Education

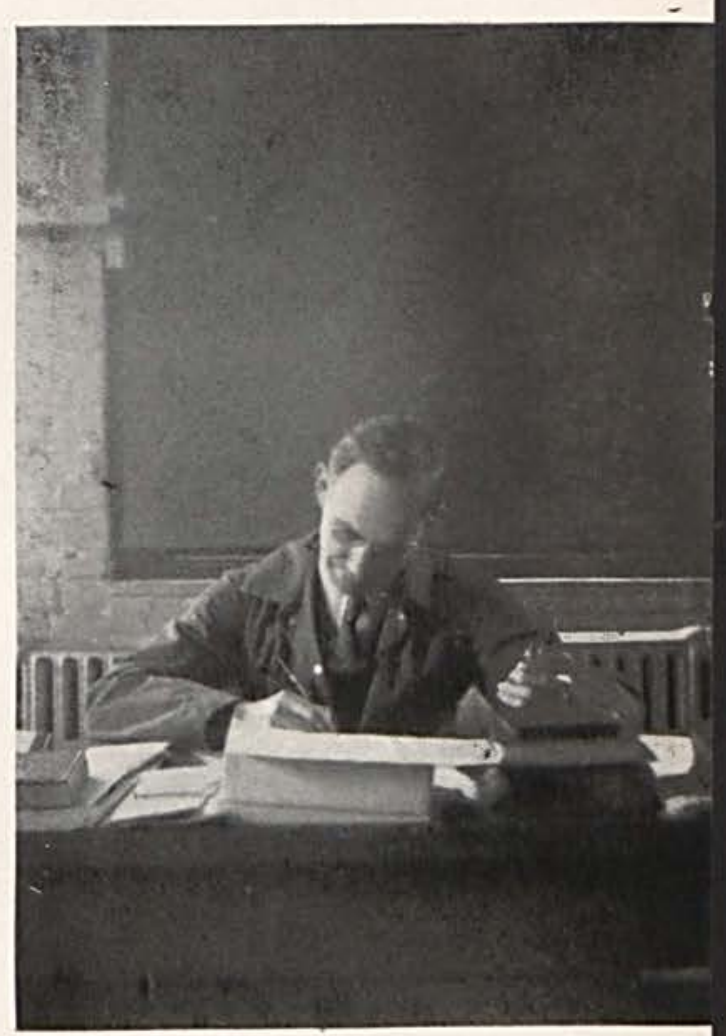


South Cukota State College, Indiana State Normal School and is now professor of Social Science and Public Speaking here at Cedarville. Mr. Steele is very conscientious in his work and as Dean of Men is doing a real service which is appreciated by all the students.

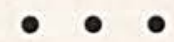

Mr. John L. Dorst continues his efficient work as business manager of the college. His wide experience as a leader and worker in the Y. M. C. A. gives him a good understand. ing of youth. $\mathrm{He}$ is congenial and always willing to do the utmost for the college and students.

Mrs. Mary Markle, a graduate of music from Ohio Wesleyan University, very ably conducted the music activities of the college during the absence of Mrs Mildred Watt Creswell. Her thorough and efficient service has made possible the progress of the music department's work with continued improvement.

For many years the students of Cedarville College have been instructed in history and modern languages by Dr. F. A. Jurkat. $\mathrm{He}$ received the degree of A.M. at Wittenberg College and has done graduate work at Ohio State University.

Students who have graduated from Cedarville will never forget the informal classes conducted by Dr. Jurkat and the variety of delicacies he serves throughout the year. Dr. Jurkat is noted for his wonderful memory and his subtle humor.

Professor Leslie Miller is a newcomer in our ranks. This year he has filled the position of instructor of Mathematics and Physics, and was also coach of the Conference Champion Yellow-Jackets. Prof. Miller did undergraduate work at Rio Grande College and Ohio University. He received his master's degree from Ohio University and worked on his doctor's degree at Ohio State. We congratulate Coach Miller for the hard work and good nature he has shown this year.

Prof. Marguerite Ault attended Bowling Green State Normal and here received her B.S, in Education in 1932

Mrs. Ault came to Cedarville in 1934, and has since been a valuable member of the College teaching staff.

She is a member of the Pi Kappa Delta Sorority.

She is one of the most popular members of the faculty and a real friend to young and old alike.

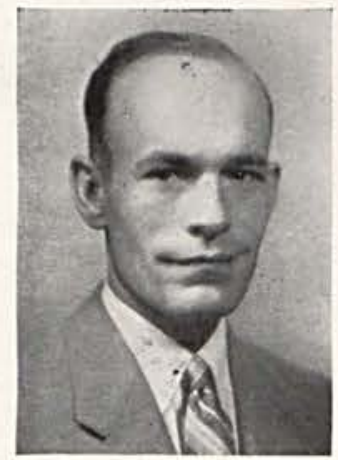

B. N. ADAMS, Student

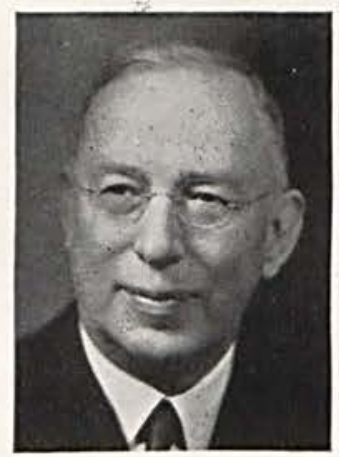

J. I. DORST, Business 
Miss Helen Santmyer, Dean of Women, is a graduate of Wellesley College, Mass., where she was instructor in English for two years. She received additional training at Oxford. England. She served as a teacher in Xenia High School.

It is a pleasure for the students of Cedarville College to have in their midst a real author like Miss Santmyar. who has had two books published. She is equally proficient in Latin and English, and is a teacher of both languages at Cedarville College.

Miss Emma Force has received two degrees, B.S. and M.A., at Ohio State University. She attended the College of Wooster, Kent State Normal, Ohio Northe:n University. Ashland College, and Western Reserve University.

She possesses a State Elementary Life Certificate. Besides her work at the college, she teaches Art at the public schools of Cedarville.

Mrs. Eloise M. Kling, professor of Elementary Education graduated from Wittenberg College. She has taught in Springfield and Clark County schools, in Ridgewood Private school, and Ridgewood Experimental school. Last summer she attended Columbia University in New York City.

Each semester she guides several elementary student; along the pathway of student teaching. Mrs. Kling is faculty adviser for the Alpha Theta Tau sorority and is doing a real service for the Cedarville young people.

Rev. B. N. Adams, pastor of the First Presbyterian Church, is the student pastor. Rev. Adams was formerly a missionary in Korea. Before coming to Cedarville, he spent seven years in Wisconsin preaching in a Presbyterian Church.

Because of his enthusiasm and interest in young people, Rev. Adams is well-liked by all the students.

Mildred Bickett Creswell was head of the Department of Music the first semester of 1938-9. She received her training at Muskingum College, Cincinnati Conservatory. and American Conservatory. She studied under such musicians as Phillipp, Boulanger, Dupre, and Wider. For three years she was Professor in American Mission College, Cairo, Egypt. She also taught in Westminster College, Utah, be fore she came to Cedarville in 1936.

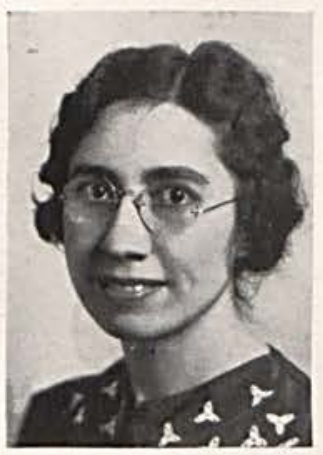

MARY C. MARKLE, Director of Music
A. B. Ohio Wesleyan
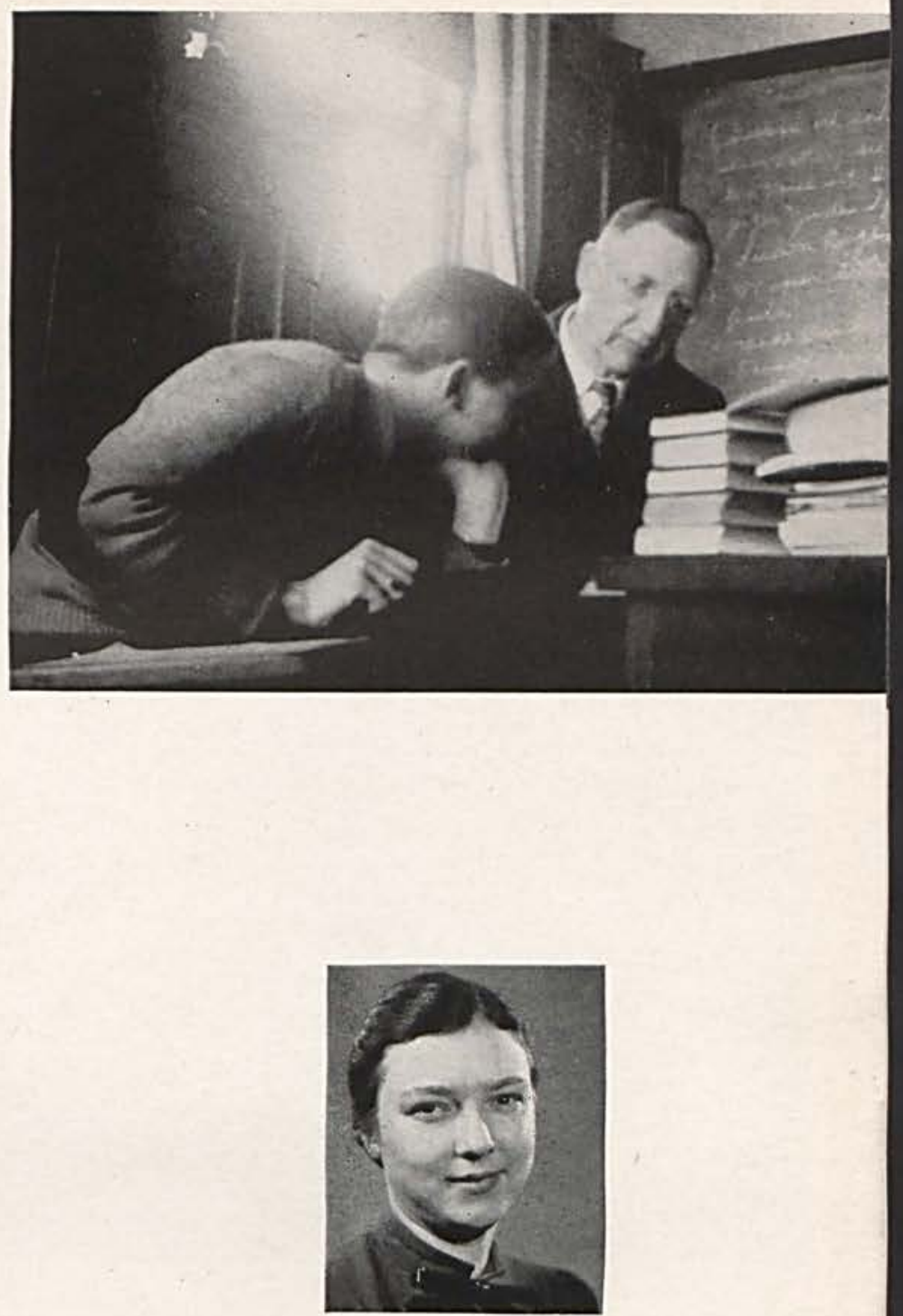

M I L D R ED HICKETT CRESWELL, Director of

A. Busic Muskingum College B. M. Muskingum Con-

M. M. Cincinnati Conservatory

Di 1 o ma. Fontainefleau, France. 
Inter-class relationship here at Cedarville College has been of great value to students and faculty. There have been programs planned by representatives of the four classes which have been enjoyed by many students. It is fine to have such a spirit of cooperation between organized classes of our student body. The social times arranged by these groups have created a greater fellowship and have inspired definite leadership on the part of various class members.

$$
\text { JOHN FOX, }
$$

Pres. Student Body.

66 I I I I I

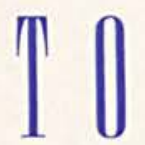

U UA R I

99 


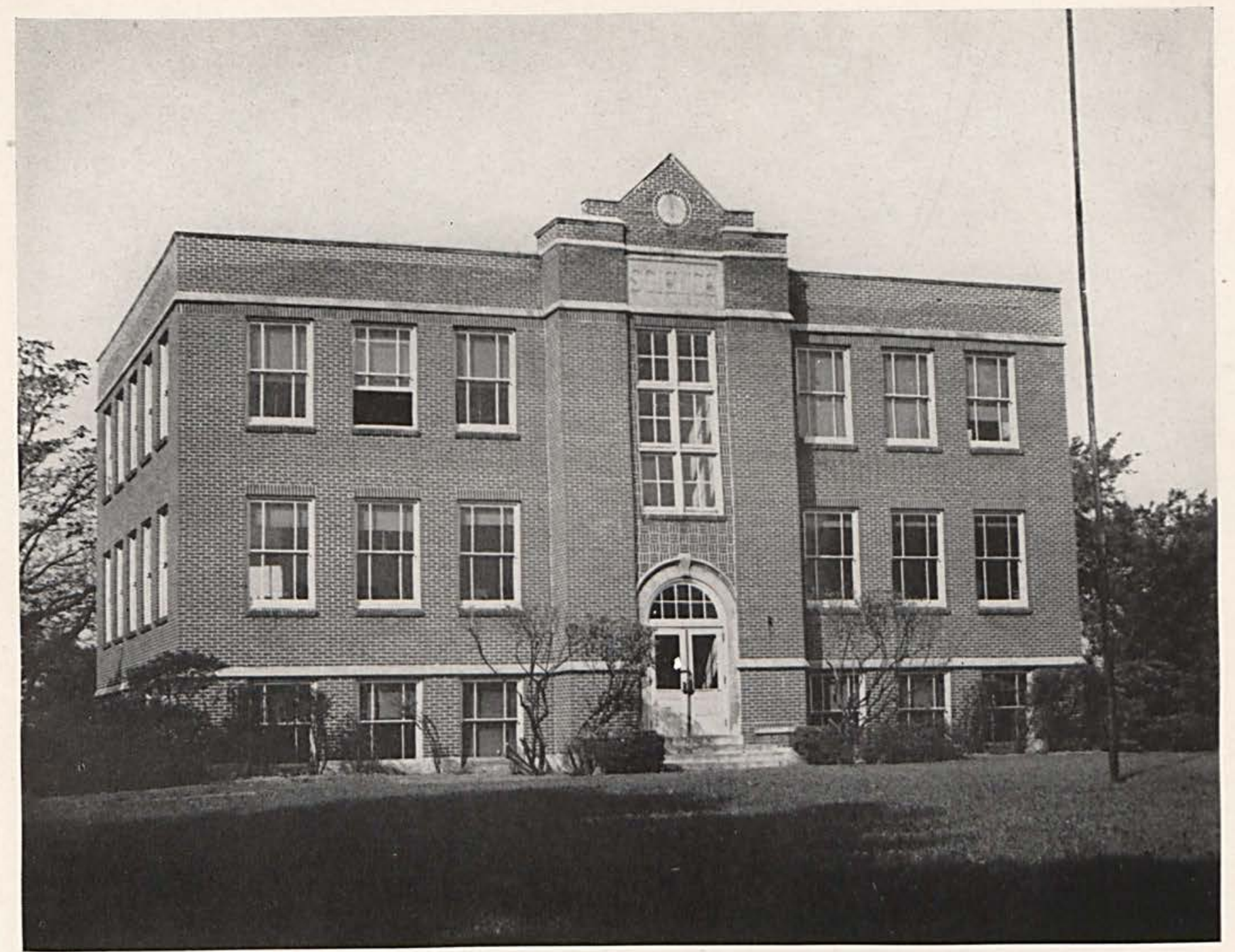

CEAREILE CLASSES

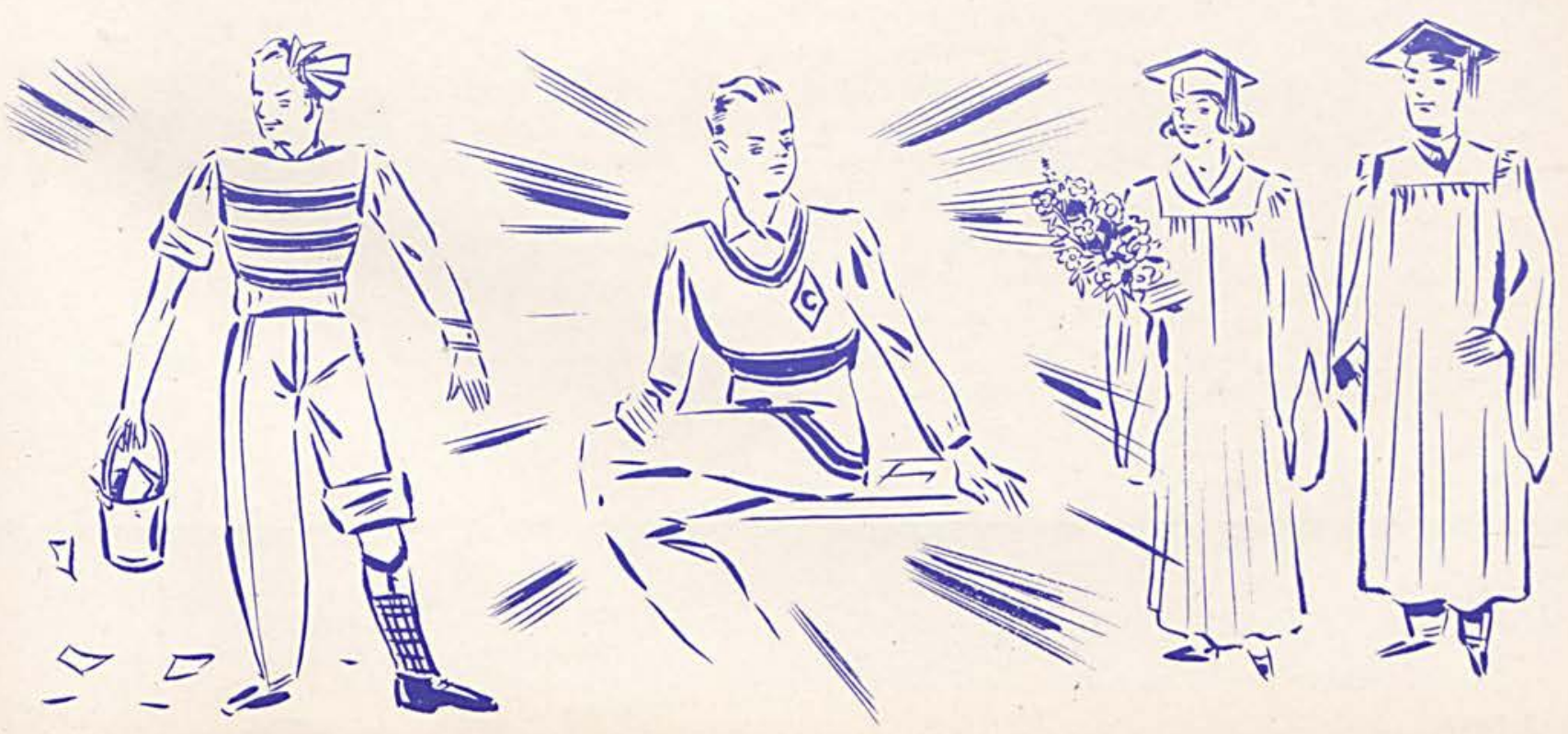



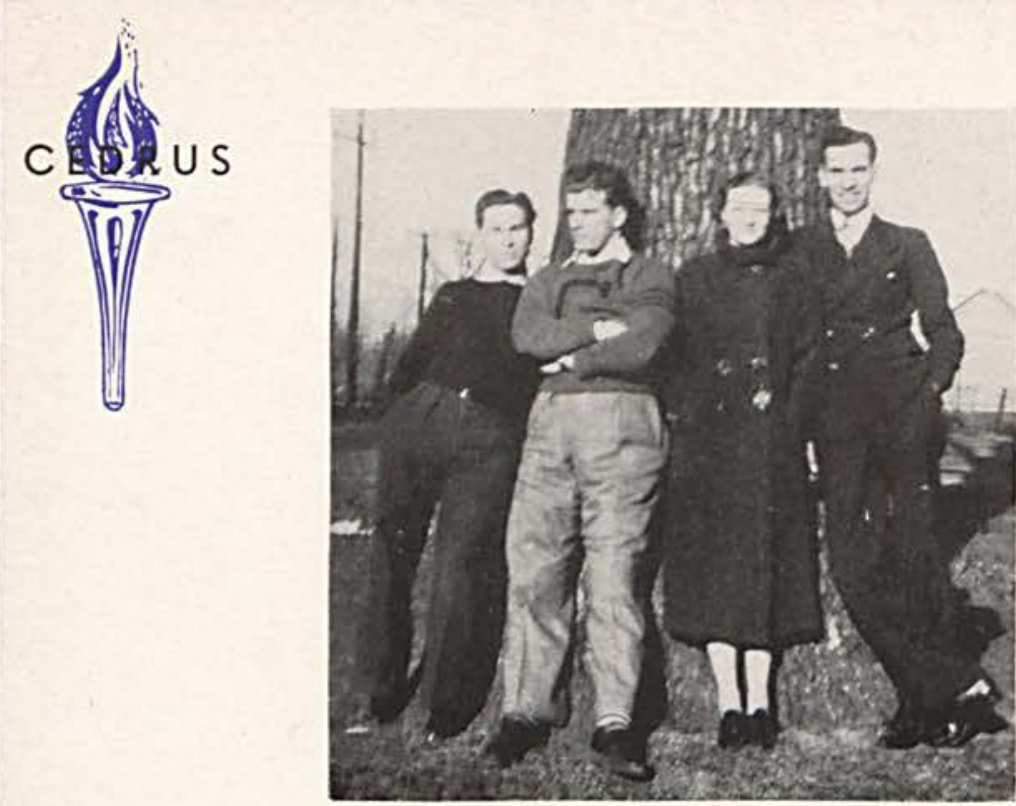

SENIOR

CLASS OFFICERS

Orval Labig. Clyde Walker, Jane Frame, Bennett McNeal.

We don't want to go. Some of us may say the last sixteen years have made us tired of school. Inside us our true voice keeps saying, "It isn't so." We want to stay. We want to keep our friends, our books, our life. We've worked with friends-the students and professors. We've lived with friends -this whole friendly community. We don't want these friendships to fade to chance or annual meetings. We want to stay.

Don't the years slip by swiftly? Only yesterday we were sixty-five strong. We pulled the typical freshman boners, perhaps a little more than we do now, but we have memories too, fine memories. We danced around the ball diamond, aided by the touch of upperclassmen's belts, splashed across Willow bend, and "tooth-brushed" the front steps. Our class was prominent in sports and other extra-curricular activities. In the fall of ' 36 we weren't so green, not so scared as we had been the year before. During our sophomore year we worked harder,-played harder, for we realized our ranks were to be divided.

Seventeen Juniors registered for the next fall term. When we weren't vorrying about our candy money we found time to make up two-thirds of the baseball nine, and two-fifths of the basketball five. The class was also active in social clubs, singing clubs, and the eating club.

This year, John Fox is President of the Student Body and Y.M.C.A. Benny McNeal is Editor of the Cedrus and Steward of the Boarding Club. Clyde Walker, a scrapper who has stayed with us in spite of serious injuries, is our class president. Jane Frame, Bea McClellan and Ray Sisson are threefourths of the Mixed Quartette. The girls have been active in sorority work. Cecil Thomas, member of both ball clubs and Steward of the Boarding Club for half the year, left us to teach at Arcanum. Ken McNeal is our ball star. He set a new record by scoring 27 points against Wilberforce. Angus Murray is our World Affairs man. Noah Sharpe is our Mr. Fixit. Mel 
BEATRICE MCCLELLAN-Y. W I, 2, 3, 4; Chi Sigma Phi 3, 4; Mixed Chorus 2, 3; Glee Club 1: Mixed Quartette 3, 4; Ced. rus Staff $2,3,4$

CLYDE WALKER - Basketball I. 2, 3, 4; Baseball I, 2, 3, 4; Y M. 1, 2, 3, 4; Class Officer 3 4; Whispering Cedars 2, 3, 4; Cedrus 3, 4; Dramatics 3, 4: Mixed Chorus I, 2; Student Council 4.

BENNETT MCNEAL-Defiance I: Cedrus 2, 3, 4: Whispering Cedars 2, 3, 4; Y. M. 2, 3, 4: Dramatics 2, 3, 4: Class Officer 3, 4; Gospel Team 2, 3: Mixed Chorus 2, 3: Basketball Manager 3: Baseball 4: Delta Kappa Sigma 2, 3, 4; Steward 4.

JAMES JACKSON-Physical Ed. Instructor 4: Baseball I, 2, 3, 4: Basketball 1, 2, 3: Referee 3, 4.

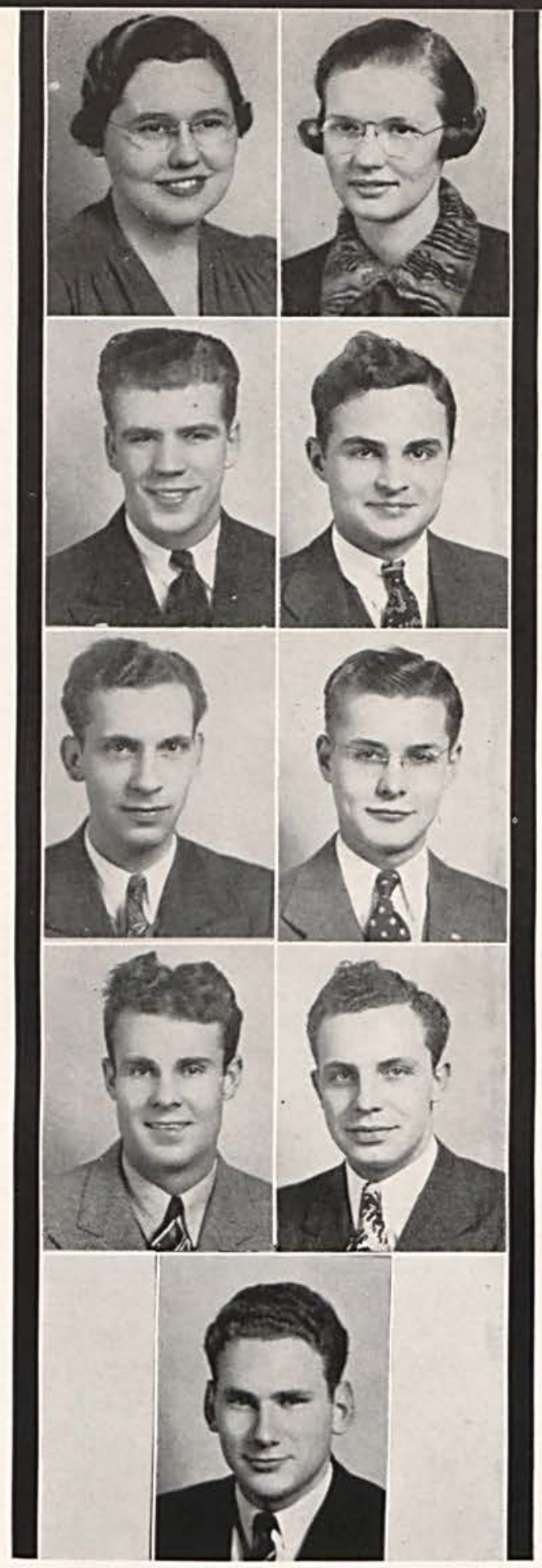

JANE FRAME-Dramatic Club I, 2, 3, 4: Y, W, I, 2, 3, 4; Mixed Quartette 3, 4; Glee Club 1, 2: Chorus 1, 2, 4: Class Officer 3, 4: Cedrus Staff 4: Student Council 4: Cheerleader 3, 4: Alpha Theta Tau 1, 2, 3 . 4: Cedar Queen 4.

JOHN FOX-Class Officer 1, 3: Student Body Pres. 4; Y. M. I, 2, 3, 4: Mixed Chorus 1, 2: Baseball 1, 4; Cedar Day Orator 4

FRED LOTT-Mixed Chorus I, 2 , 3, 4: Quartette 2, 3, 4: Delta Kappa Sigma 2, 3, 4; Dramatic Club 2, 3, 4; Y. M. 2, 3, 4; Officer of $Y, M .4$. Basketball Manager 4: Ass't Steward 4: Cedrus Staff 4: Whispering Cedars 2, 3; Crown Club 3.

KENNETH MCNEAL - Defiance 1: Basketball 2, 3, 4: Baseball 2. 3, 4: Y. M. 2: Dramatics 2 3: Delta Kappa Sigma 2, 3, 4: Mixed Chorus 2.

CECIL THOMAS-Class Officer 3, 4; Y. M. 1, 2, 3, 4; Baseball I, 2, 3: Basketball 1, 2, 3, 4; Delta Kappa Sigma 4; Dramatics 1, 2, 3, 4; Cedrus Staff 3. 4: Whispering Cedars 3. Steward 4; Crown Club 3. 
AREMA HAYS-A. B. Miami

University: Dramatic Club 4;

Y. W. C. A. Team 4 .

RAYMOND SISSON-Class Officer 2, 3, 4; Cheerleader 2; Y. M: I, 2, 3, 4; Music 1, 2, 3, 4; Baseball 2, 3, 4: Tennis Champ 4; Delta Kappo Sigma 2, 3, 4; Crown Club 3: Whispering Cedars 2, 3: Cedrus Staff 2.

MELVIN THOMPSON-Baseball I, 2, 3, 4; Y. M. I, 2, 3, 4 .

KENNETH DEETER - Indianapolis Normal I, 2; Basketball 1: Track 1: Phi Epsilon Kappa 1, 2.

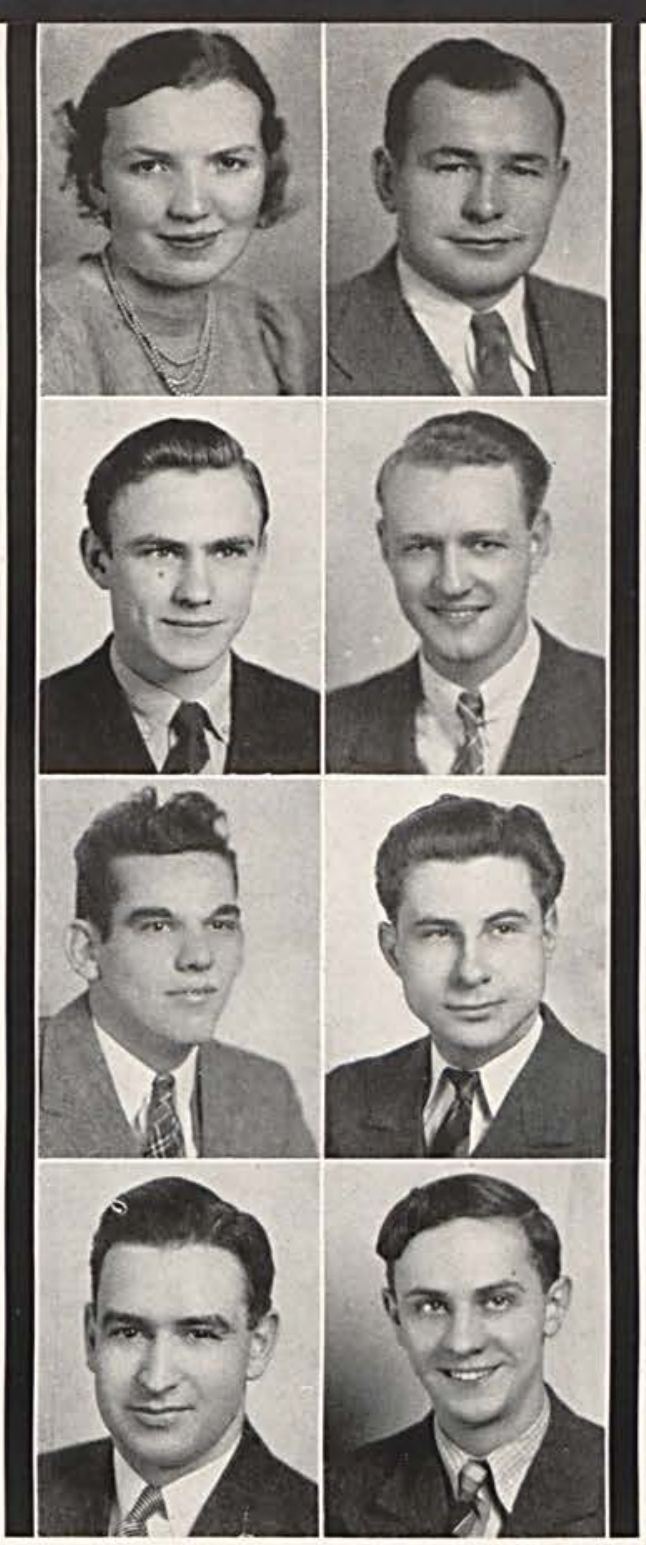

ANGUS MURRAY - Y M 1,2 . Baseball Manager 4: Dramatics Club 1: Mixed Chorus I.

NOAH SHARPE-Delta Kappa Sigma 2, 3, 4; Y. M. 1, 2, 3, 4; Gospel Team 2: Dramatic Club 2: Student Council 3.

ORVAL LABIG-Class Officer 3 : Y. M. I, 2, 3; Baseball Manager 1: Dramatic Club 2, 3 ; Mixed Chorus 1: Delta Kappa Sigma 3.

VIC SHAW-Y. M. I, 2, 3, 4: Mixed Chorus 4. 


\section{J I I I I I R}

CLASS

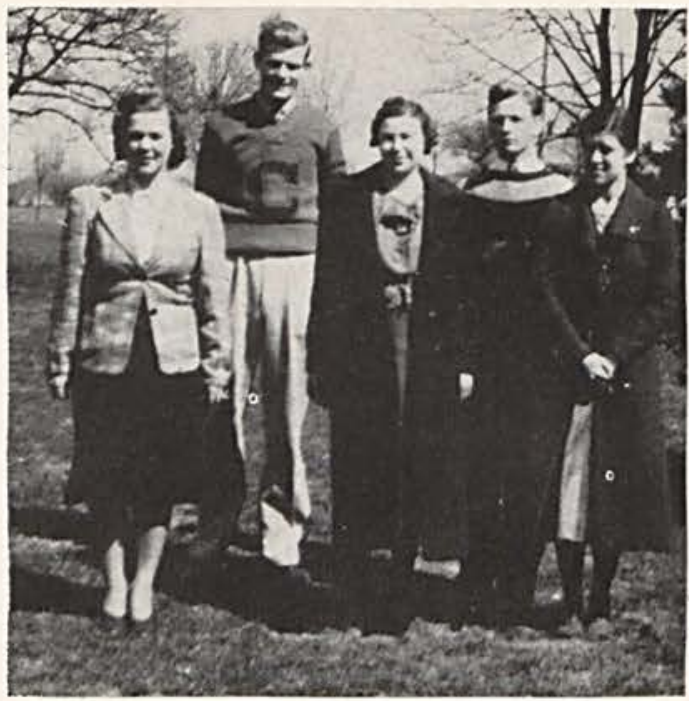

CLASS OFFICERS

Donna Zellar, Russel Roberts, Grace Bickett, Royden Johnson, Irene Goodin.

Early in September in the fall of 1936, 42 "freshies" began their eventful college careers. That year our activities were guided by our capable president, Eldon Gillespie. Other officers of our class were Russel Roberis, vicepresident; Geneva Clemans, secretary; John Peterson, treasurer; and Genevieve Jesson, reporter. After several of what we called "trying-days" we were glad to see Freshman Week come to an end. The girls will long remember how they had to scrub mud off the front steps of the main building with tooth brushes, as will the boys remember the "ducking" they got out at Willow Bend when the upper classmen pulled them in.

Most of these freshmen returned in the fall of 1937 to begin another thrilling year at college. This year we were under the leadership of President John Peterson, assisted by Genevieve Jesson, Catherine Harbaugh, and Monroe Pyles. This year we were well represented in the various fields of athletics. Several of our members also took part in music, dramatics, and other activities of the college. These days found many of our class worrying over "that thing" of practice teaching. At crmmencement time we found many of our class going out to teach others. Reports come back to us that all of these are doing very good work in this field.

As we came back for our third year at Cedarville, we found there was a much smaller group than we had had in previous years. We began this year with only twelve members. Russel Roberts was elected president of the class with John Peterson as vice-president; Grace Bickett, secretary; Irene Goodwin, treasurer; and Donna Zeller, reporter. This year, as Juniors, we have charge of the candy business.

As our class was so small and the Senior class was small also, these classes decided to hold their class parties and socials together instead of each class holding them separately.

Again we are represented in athletics and other extra-curricular activities. From this small group we furnished two winners in the Women's Bible Reading contest and one in the men's contest. Since we did not have a class play this year, the big occasion of the year was the Junior-Senior Banquet held at Dayton.

And now we are anxiously looking forward to our senior year and looking back over the happy years we have already spent at Cedarville.

PAULINE FERGUSON.

Junior. 


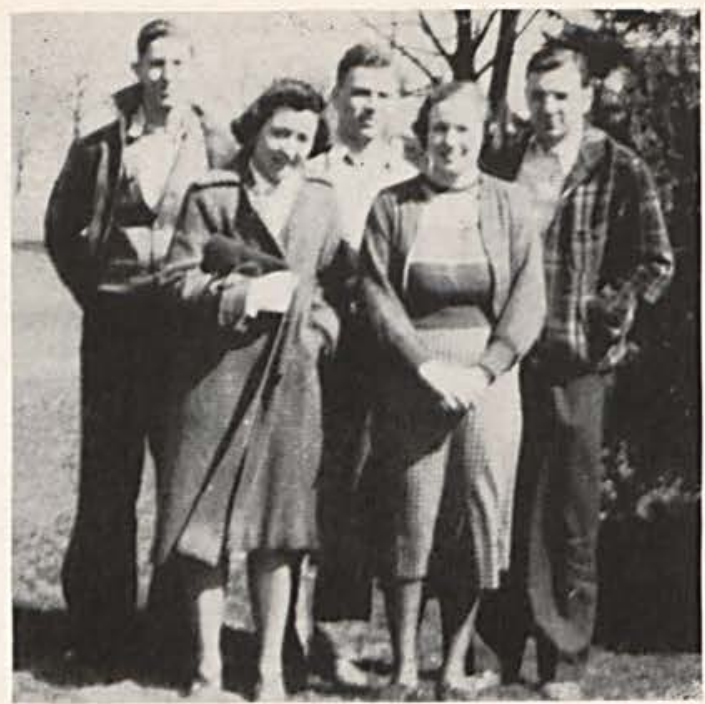

\section{S D P I I I II O R I I}

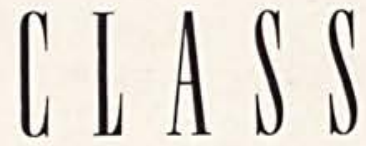

\section{CLASS OFFICERS}

Neil Hartman, Rachel Harriman, Clayton Wiseman, Marie Collins, Justin Northup.

\section{SOPHOMORE CLASS HISTORY}

Last year forty-two freshmen entered Cedarville College to pursue a college education.

At our first class meeting, we organized and elected Richard McKnight as our class president.

We were duly initiated into our new college life by the sophomores and the rest of the upper classmen. However, we nobly survived the humiliation of make-up on the boys and make-up off the girls along with nice long walks in the darkness of the moon and a nice cool, refreshing dip in Willow Bend.

After this traditional week, we settled down to a normal college life and were quickly absorbed into the college activities.

Two of our members received letters in basketball and one earned a letter in baseball. Our class also contributed to the musical organizations of the college. Four members were in the organ class and a girls' quartette was formed from girls of our class.

Although three members of last year's class quit during the summer and one succumbed to the holy bonds of matrimony last semester, we gained five new students this year from other colleges and are still going strong.

At our first class meeting this year, we elected Clayton Wiseman as our class president; Neil Hartman as vice president: Marie Collins as treasurer: Charlotte Turner as class reporter, and Justin Northup as student council representative.

Four members of our class were on the varsity basketball team this year and of course, the sophomores won the class tournament. Five boys of our class are out for baseball this spring. Many members sing in the college choir and one is in the college quartette. Several have participated in dramatics. This year we have conducted many successful class parties including two skating parties at Dayton, a coasting party, and an all college sweater swing. Seventeen sophomores in the normal department have been engaged in practice teaching during a part of the year, and they are anxiously looking forward to the next few years when they will be school teachers and after that-well, they are hoping for the best.

NEIL HARTMAN,

Vice President. 



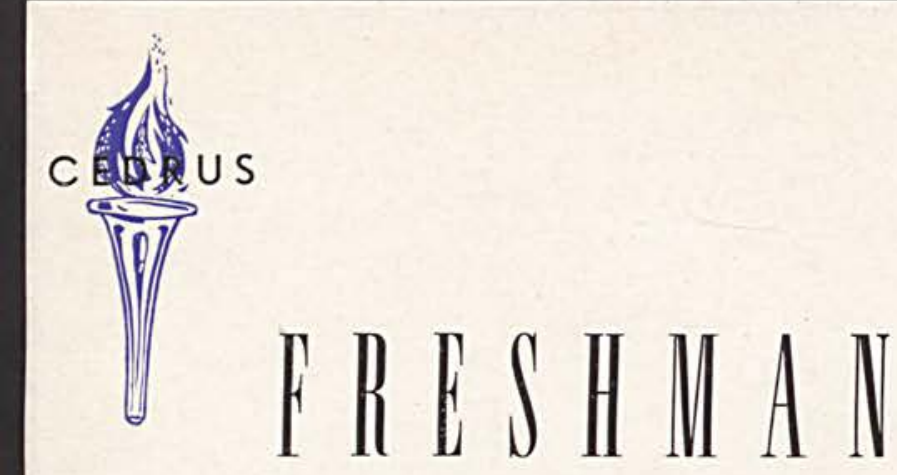

$$
\text { CLASS }
$$

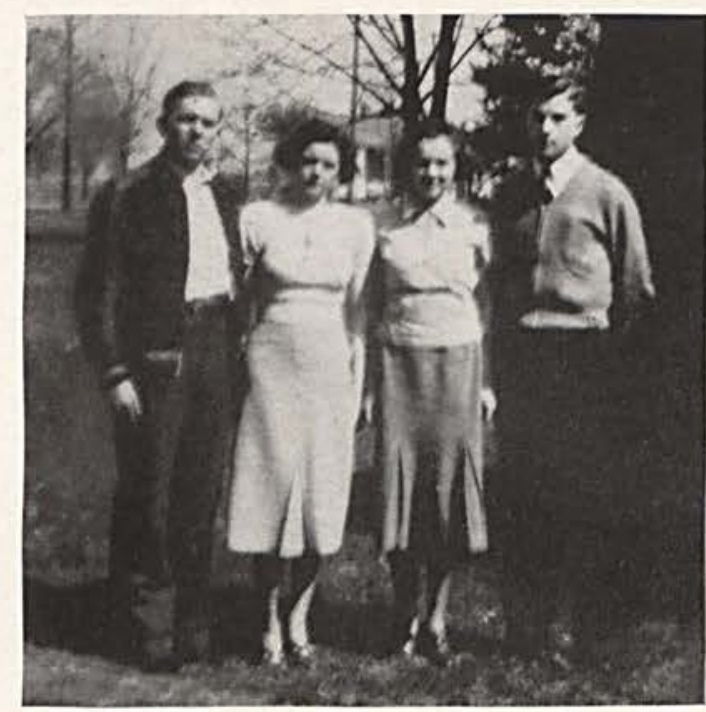

CLASS OFFICERS

Norman Linton, Janette Neal, Orsadee Stewart, Fred Little.

\section{FRESHMAN CLASS HISTORY}

On Sept. 8, 1938 thirty-one embarrassed and homesick Freshmen set foot on the campus of Cedarville College. On Sept. 22, they met to choose their class officers. The following people were elected: Robert Peterson, president: Orsadee Stewart, vice president: Norman Linton, secretary and treasurer: Jay Peterson, news reporter; and Janette Neal, student council representative.

The upper classmen had no pity for these Freshmen; they heaped torment upon trouble. There were many peculiar sights around the campus. Girls with braided hair, unmated shoes and hose, excessive amounts of jewelry, books in buckets, and sacks of candy were a common sight. At that time it was rumored that some of the girls gave Dr. Jurkat candy in order to raise their grades. The tug of war at Willow Bend was rather onesided. The sophomores used a safety measure, tying the rope to a stump, but the Freshmen (almost) pulled Sophomores, stump and all into the water.

At the beginning of the second semester Robert and Jay Peterson were unable to return. It was necessary that new officers be put in their places. Norman Linton was elected president: Fred Little, secretary and treasurer, and John Reinhard, news reporter. Other officers remained the same. Although we have had a few bad moments the year has been an eventful and happy one. We are looking forward to our Sophomore year with great anticipation.

\section{ANNE RITENOUR,}

Freshman. 


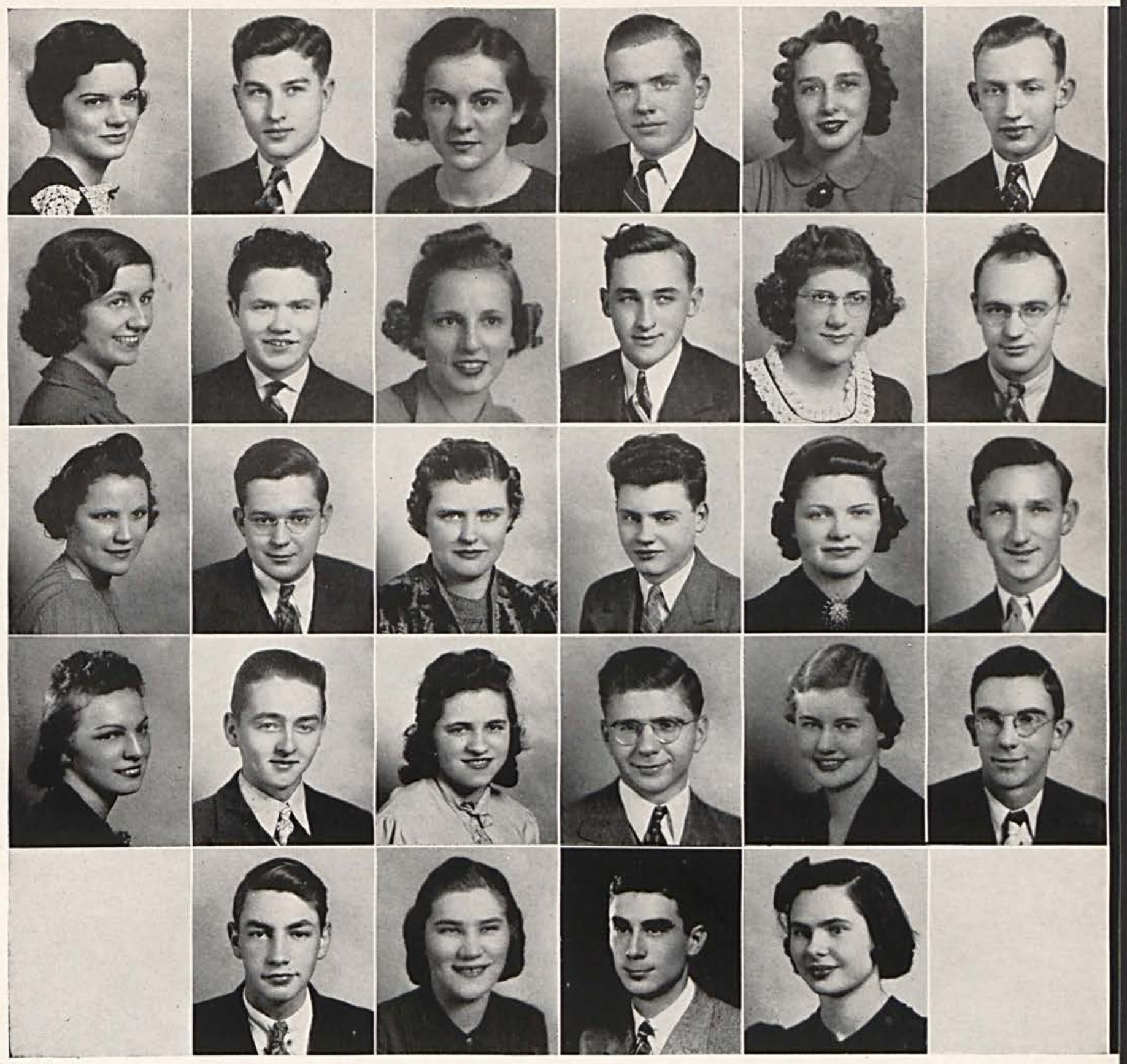

FIRST ROW (Beginning at top)-Janette Neal, Fred Little, Orsadee Stewart, Norma Linton, Emma Mae Stebbins, Layden Wilson.

SECOND ROW - Vona Ruth Owens, Ned Brown, Anne Ritenour, George Smith, Janice Finke, Robert Sears.

. THIRD ROW-Margaretta Lott, John Brill. Mary Elizabeth Batdorf, Thomas McQuillen, Helen Ross, Clayton Moore.

FOURTH ROW-Betty Nelson, Wayne Dibble, Hazel Bush, Robert Guthrie, Anna Mary McClellan, John Reinhard.

FIFTH ROW-Jay Peterson, Kathrine Randall, John Bickett, Isabel McClellan. 
Our organizations, some of them founded many years ago, are one of the most important parts of the life of a student because they have so successfully carried out their aims and purposes. The social activities sponsored by these groups promote fellowship among the students and offer many opportunities for students to demonstrate their qualities of leadership. We hope that through the activities of our organizations we may gain experience which will make us efficient leaders and workers in the future.

JANE FRAME,

Organizations Editor.
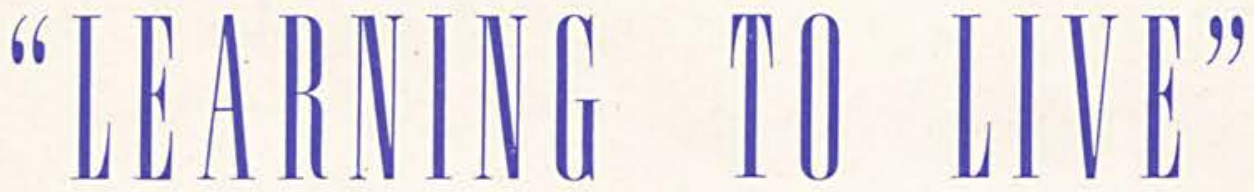


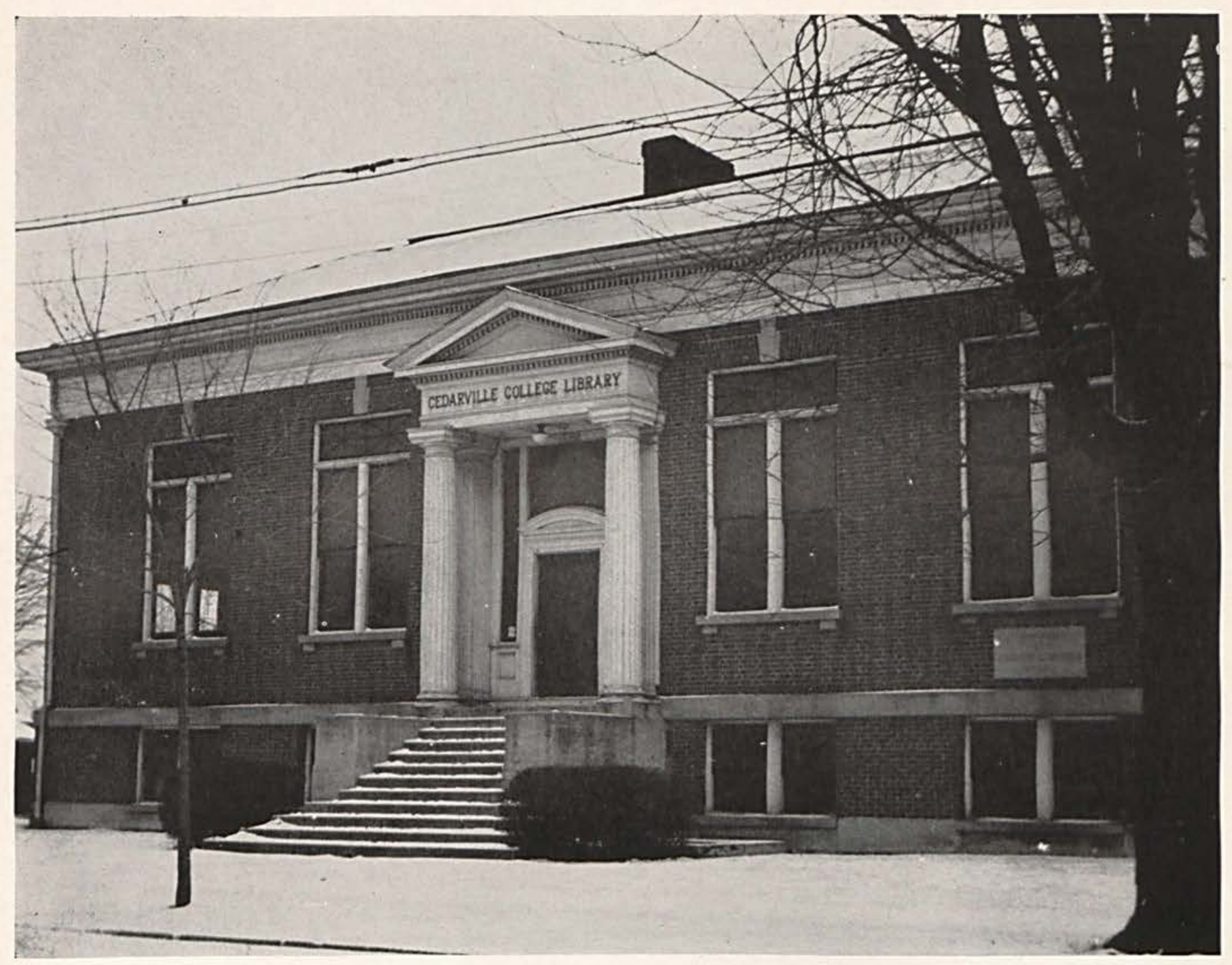

\section{CEARIILE ORGAMLATINIS}

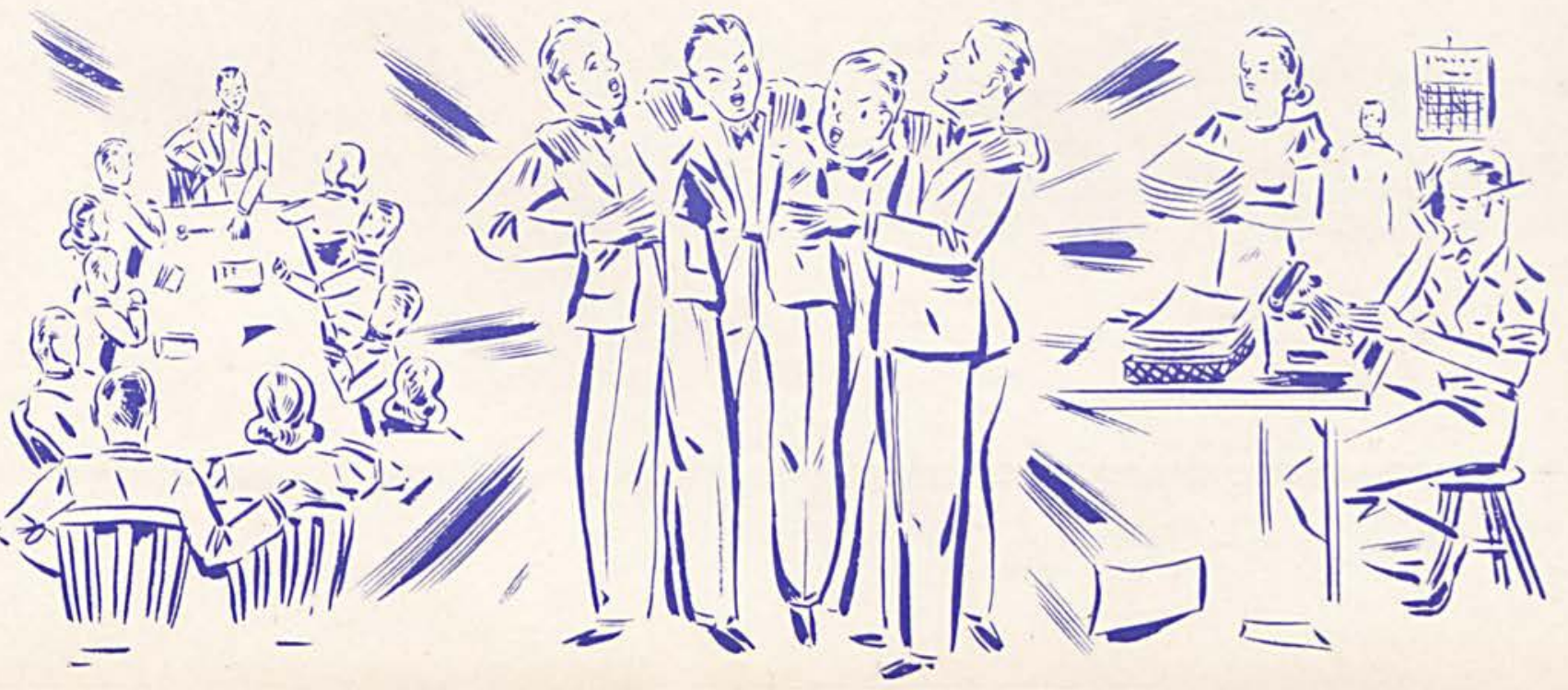




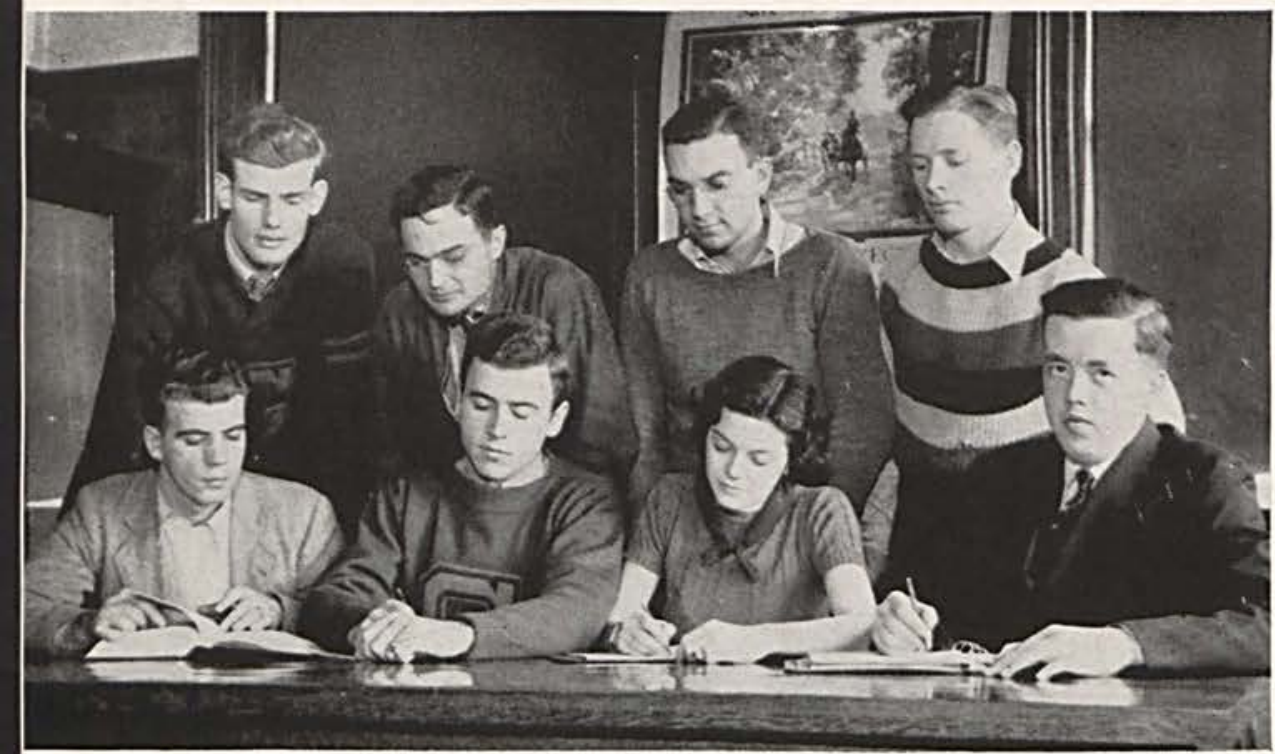

SITTING-Clyde Walker, Clayton Wiseman, Janette Neal, Robert Peterson.

STANDING - Russel Roberts, John Fox, Justin Northup, Royden Johnson.

The Student Council, composed of representatives of the student body and faculty, was organized to take care of any problems of school government that might arise.

The Council is composed of the student-body president and secretary, presidents and representatives of the classes, the president of the college and the deans.

The Council is composed of the following members: John Fox, Chairman and student-body president: Jane Frame, student-body secretary; Clyde Walker, Russel Roberts, Clayton Wiseman, and Robert Peterson, presidents of the senior, junior, sophomore, and freshman classes. Representatives of these classes in addition to the presidents are Raymond Sisson, senior: Royden Johnson, junior; Justin Northup, sophomore and Janette Neal, freshman. After the withdrawal of Robert Peterson, Norman Linton was elected freshman class president and took Peterson's place on the Council.

Faculty representatives are Dr. W. R. McChesney, president of the college, Miss Helen Santmyer, dean of women, and C. W. Steele, dean of men.

JANE FRAME,

Secretary Student Council. 


\section{LERRIS STAPH}

Work on the Cedrus has been progressing for several months. The supreme desire of the staff in making this book for you was to have it full of pleasant memories of our Alma Mater.

Much credit for this production goes to our editor for his faithful service and to our faculty adviser for his guidance. Each member of the staff has willingly contributed his talent and time. The various organizations have aided greatly by the many activities which they have sponsored during the year. To these we are grateful, and to any others who have in any way contributed to the success of our book.

It is hoped that when you turn these pages in the years to come a smile, perhaps a tear, may appear. Memories of days spent at old C. C. will flash across your mind, bringing great joy. If these pages bring you pleasure in the future, our Cedrus has been a grand success.

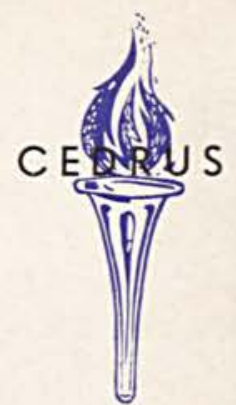

BEATRICE MCCLELLAN,

Typist.

FIRST ROW - Russel Roberts, Fred Lott, Mary Jean Towns. ley. Cecil Thomas, Jane Frame. Clyde Walker.

SECOND ROW-Clayton Wiseman, Beatrice McClellan, John Peterson, Pauline Ferguson, Elisabeth Anderson, Maris Col. lins, Bennett McNeal.

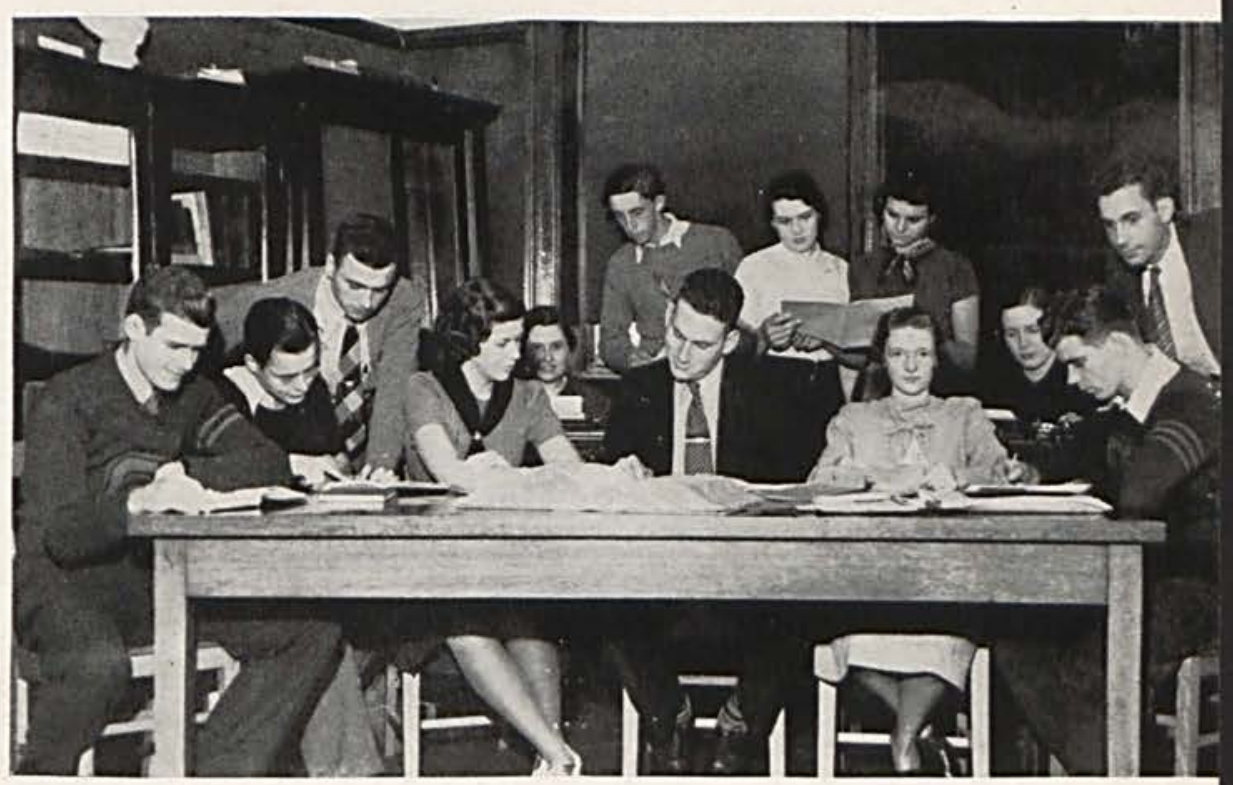




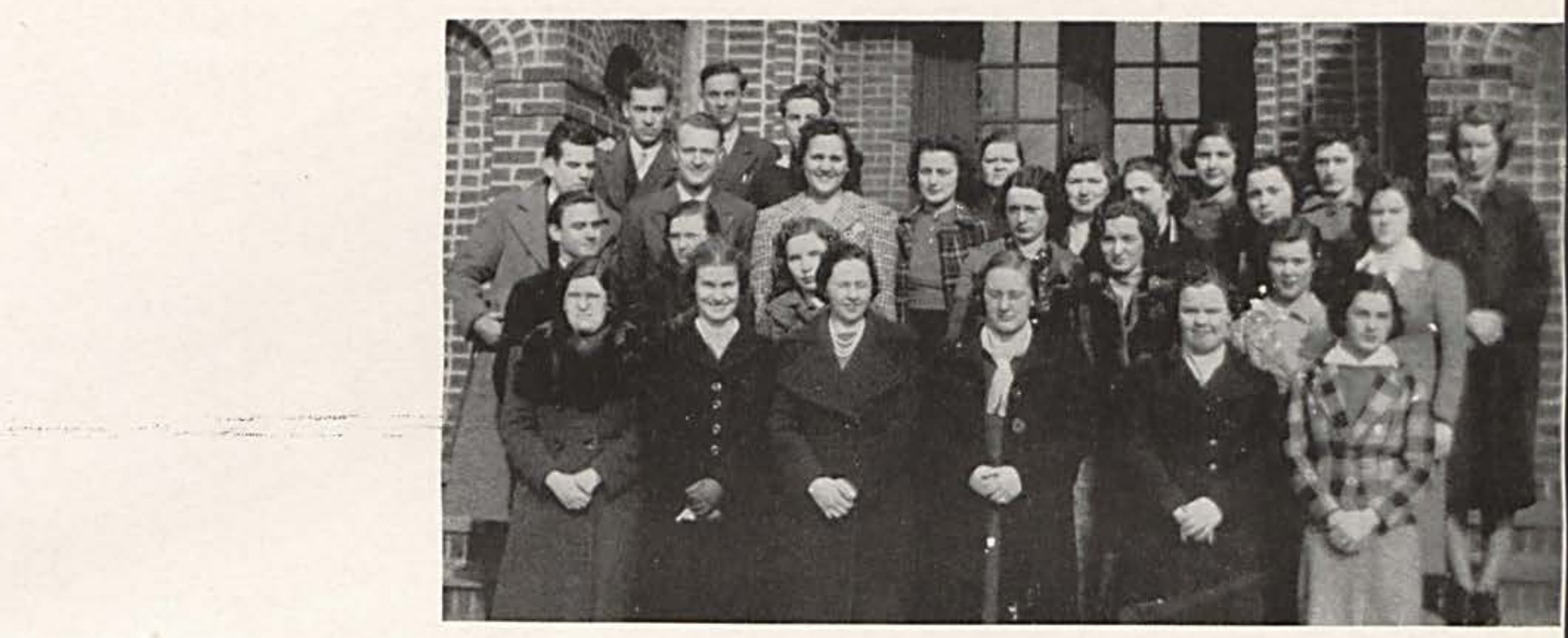

FIRST ROW-Mary Louise Conover, Rachel Creswell, Hazel McClellan, Virginia Lewis. Louise Cosler, Margaret Olinger.

SECOND ROW-Ray Sisson, Jane Frame, Florence Ferguson, Ruth Stoddard, Jean Elliott, Donna Zeller.

THIRD ROW-Mel Thompson, Noah Sharpe, Dorothy Kennon, Wanda Griffith, Ruth Booher, Merieum Foulk, Rosenni Guthrie, Opal Seamon.

FOURTH ROW-Bennett McNeal, Victor Shaw, Orval Labig, Barbara Carter, Beatrice Gray, Marcella Tobin, Betty Rowe.

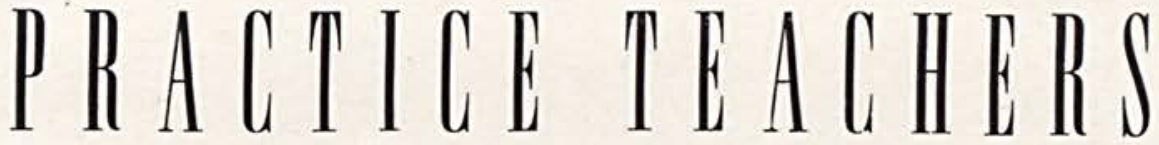

During both semesters this year we have seen groups of practice teachers working busily on lessons for their classes in the grades and high school. (We suspect that some of them had to work fast in order to keep ahead of their pupils.) There were eleven teachers in the elementary division the first semester. All of these did their work in the Cedarville schools, as did the four high school teachers of the same period.

In the second semester, there were four elementary and four high school teachers who did their practicing at Ross Township School. These student teachers were able to finish the required work in less time than the group which taught in Cedarville by conducting two classes each afternoon. There were nine elementary and four high school student teachers in the Cedarville schools the second semester.

In spite of the many mistakes which were made, and the often discouraging attitudes of the pupils, the teachers feel that they have gained from their experiences much valuable knowledge which will be useful when they have classes of their own.

JANE FRAME. 


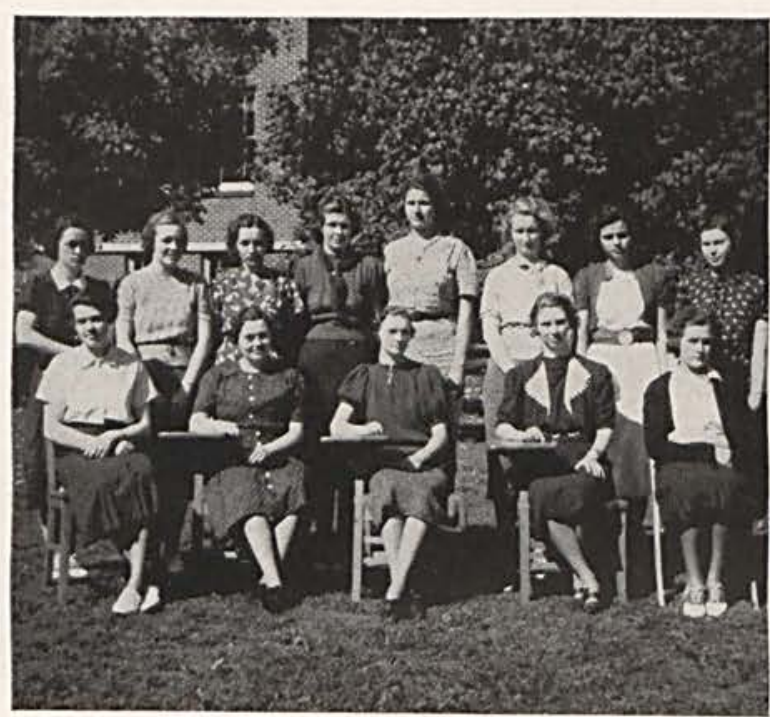

Y. W. CABINET

SITTING-Pauline Ferguson, Beatrice McClellan, president Jane Frame, Glenna Basore, faculty adviser, Virginia Townsley.

STANDING - Ruth Stoddard, Marie Collins, Jean Elliott Mary Jean Townsley, Beatrice Gray. Betty Rowe, Elisabeth Anderson, Grace Bickett.

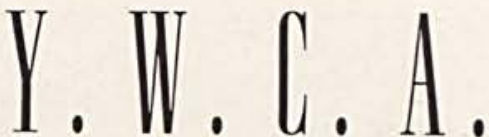

The Y. W. C. A. has enjoyed a year of interesting meet. ings, many of which were jointly with the Y. M. C. A., and social times together. The first week of school the freshman girls were welcomed into the organization by a tea at the home of Dr. and Mrs. McChesney.

Following the usual custom, the girls drew names for $\mathrm{Se}$. cret Pals and exchanged gifts. To climax this event, a Secret Pal party was held at the home of Jane Frame iust before Christmas vacation.

The $Y$. W. attended the first basketball game of the season in a body after having enjoyed a chili supper and the mock wedding at the home of Mary Jean Townsley. The organization tried something new this year in the form of a St. Patrick's Tea held in the gym on St. Patrick's Day.

A number from our group attended the Southern Ohio Area Conference that was held in Columbus in April. Much was gained from fellowship with students of other colleges.

As a climax of our activities of the year the girls and their mothers and friends enjoyed a social time together at the annual Mother and Daughter Banquet, which was held on the Friday evening before Mother's Day.

BETTY ROWE

Publicity Chairman.

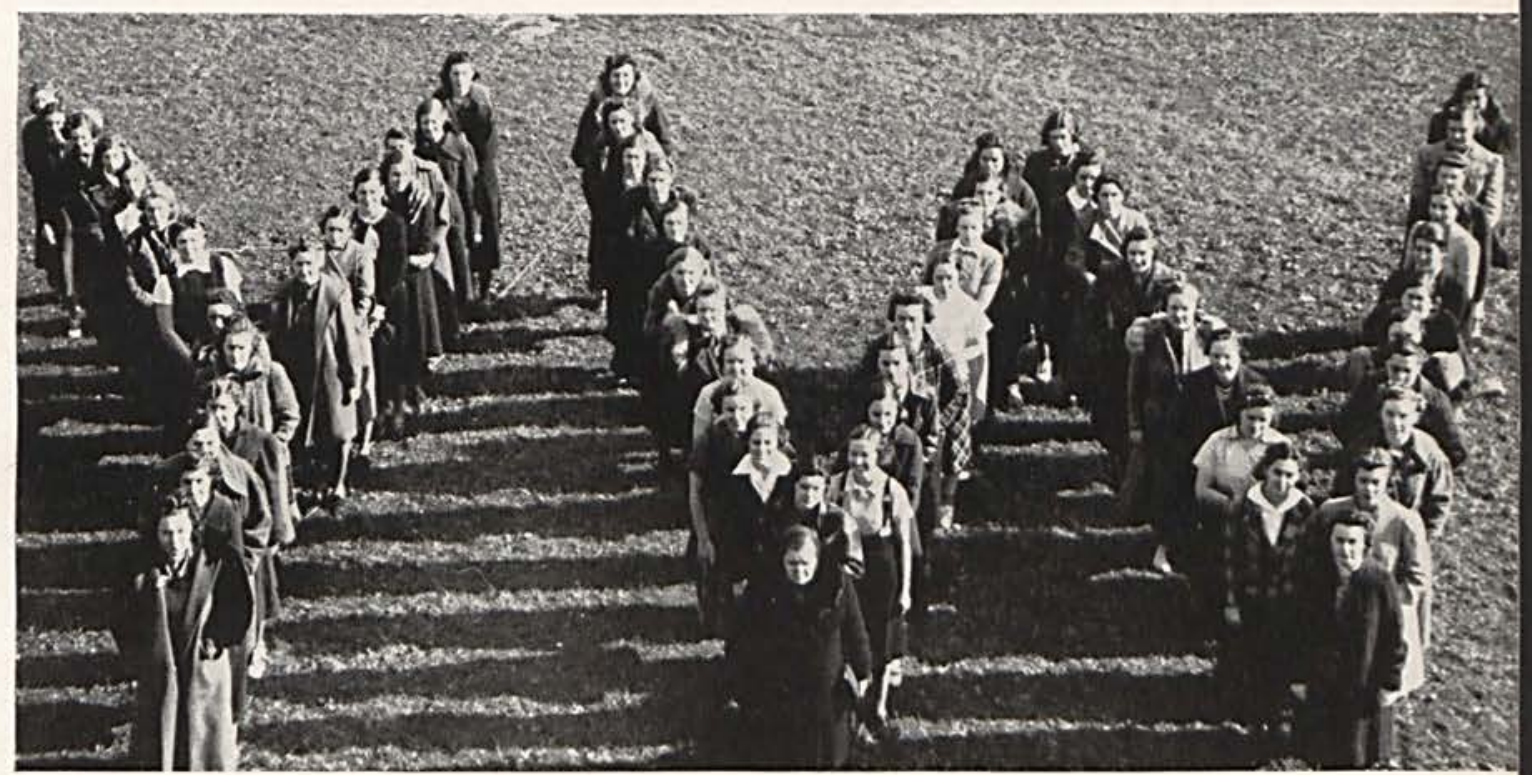

Merieum Foulk, Orsadee Stewart, Isabel McClellan, Janice Finke, Betty Nelson, Betty Rowe, Ruth Booher, Ruth Stoddard, Virginia Townsley, Helen Chitty, Beatrice McClellan, Vona Ruth Owens, Mildred Williams, Mary E. Edgington, Jean Elliott, Junia Creswell, Marie Collins, Pauline Ferguson, Anna Mary McClellan, Orena Marshall, Dorothy Kennon, Marcella Tobin, Grace Bicket, Glenna Basore, Jane Frame, Arema Hays, Doris Ramsey, Louise Cosler, Margaretta Lott, Opal Seamon, Janette Neal, Barbara Carter, Clarabell Ankeney, Beatrice Collier, Rosenni Guthrie, Wanda Griffith, Mae Stebbins, Anna Ritenour, Charlotte Turner, Elisabeth Anderson. Mary Jean Townsley, Rachel Harriman, Marguerite Ault, Louise Jacobs, Virginia Lewis, Hazel McClellan, Hazel Bush, Margaret Olinger, Bernice Rosher, Donna Zellar. Florence Ferguson, Rosalyn Guthrie, Helen Mossbarger, Mary Louise Conover, Irene Goodin, Kathrine Randall. Helen Ross, Mary Batdorf. Beatrice Gray. 


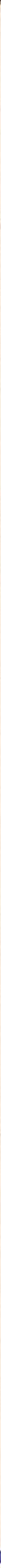


FIRST ROW-Elisabeth Anderson, Mary Jean Townsley, Glenna Basore, Arema Hays, Beatrice Collier, Anna Mary McClellan, Clarabelle Ankeney, Opal Seamon, Jane Frame.

SECOND ROW-Louise Cosler, Thomas McQuillen, Ruth Stoddard, Mae Stebbins, Merieum Foulk, Ray Sisson, Beatrice McClellan, Rosenni Guthrie, Janice Finke, Isabel McClellan, Betty Nelson, Rosalyn Guthrie, Florence Ferguson, Ruth Booher. Wanda Grif. fith, Vona Ruth Owens, Hazel McClellan, Bernice Rosher, Norman Lin. ton, Janette Neal, Bennett McNeal, Clyde Walker.

THIRD ROW-Dick McKnight, John Reinhard, Wayne Dibble, Noah Sharpe, Clayton Wiseman, Cecil Thomas, Russel Roberts, Jay Peterson, Royden Johnson, Justin Northup. Orval Labig, Neil Hartman.

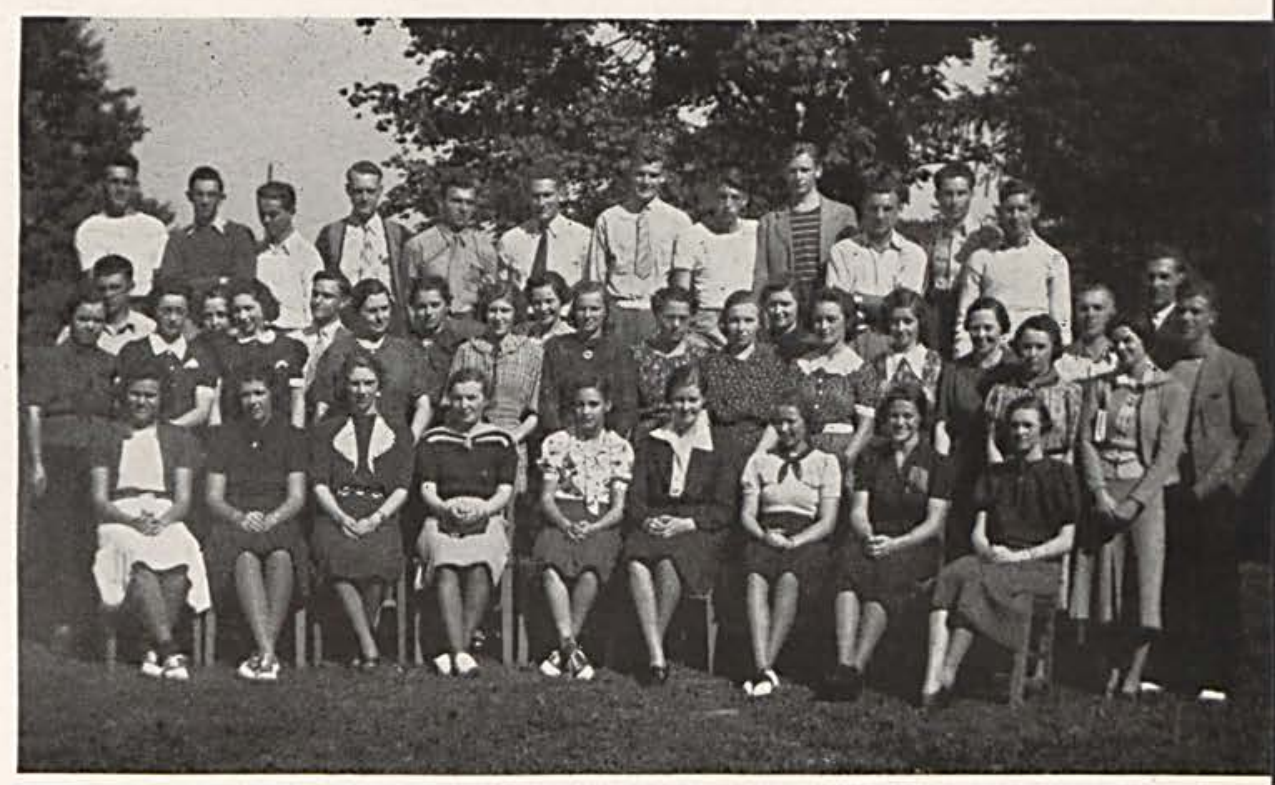

\section{OFFICERS}

Elisabeth Anderson, secy-treas.: Neil Hartman, president: Jane Frame, vice-president.
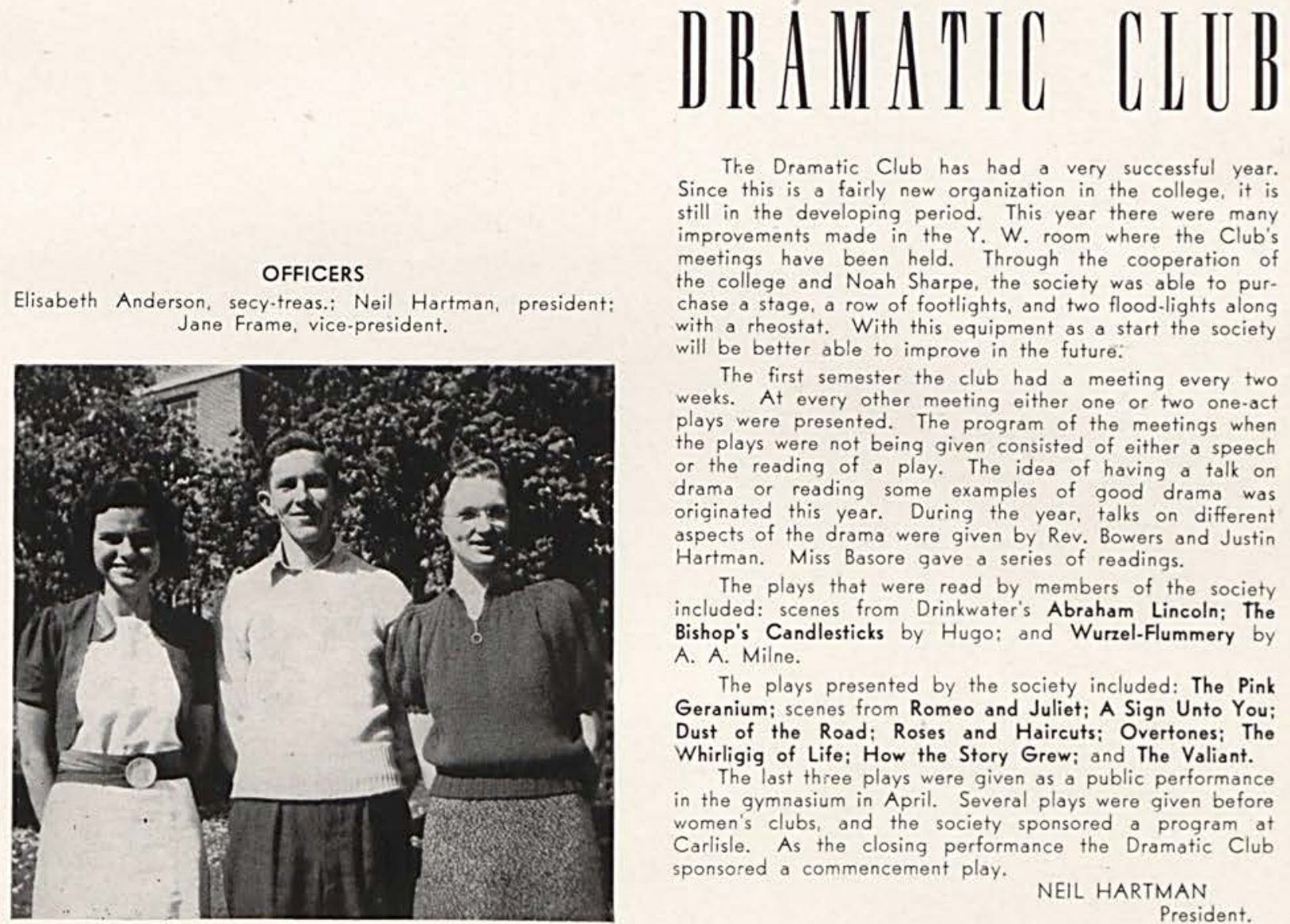

The Dramatic Club has had a very successful year. Since this is a fairly new organization in the college, it is still in the developing period. This year there were many improvements made in the Y. W. room where the Club's meetings have been held. Through the cooperation of the college and Noah Sharpe, the society was able to purchase a stage, a row of footlights, and two flood-lights along with a rheostat. With this equipment as a start the society will be better able to improve in the future:

The first semester the club had a meeting every two weeks. At every other meeting either one or two one-act plays were presented. The program of the meetings when the plays were not being given consisted of either a speech or the reading of a play. The idea of having a talk on drama or reading some examples of good drama was originated this year. During the year, talks on different aspects of the drama were given by Rev. Bowers and Justin Hartman. Miss Basore gave a series of readings.

The plays that were read by members of the society included: scenes from Drinkwater's Abraham Lincoln; The Bishop's Candlesticks by Hugo: and Wurzel-Flummery by A. A. Milne.

The plays presented by the society included: The Pink Geranium; scenes from Romeo and Juliet; A Sign Unto You; Dust of the Road; Roses and Haircuts; Overtones; The Whirligig of Life; How the Story Grew; and The Valiant.

The last three plays were given as a public performance in the gymnasium in April. Several plays were given before women's clubs, and the society sponsored a program at Carlisle. As the closing performance the Dramatic Club sponsored a commencement play.

NEIL HARTMAN

President. 

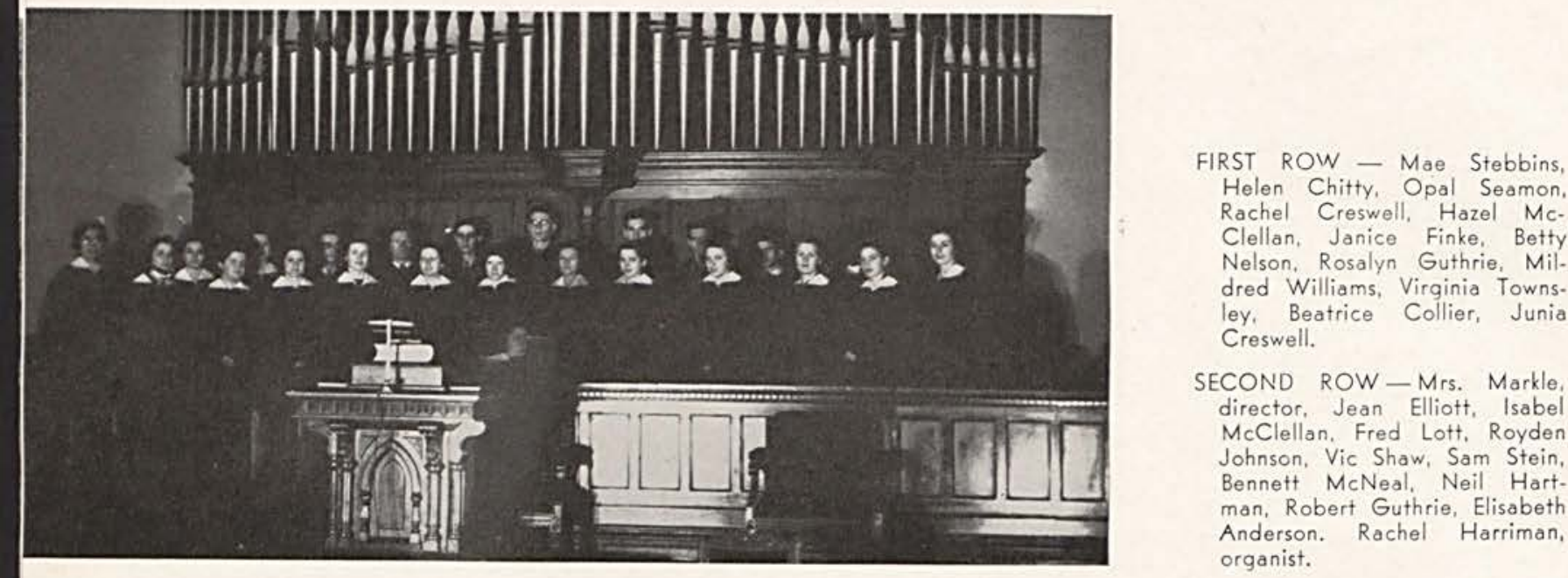

SECOND ROW - Mrs. Markle director, Jean Elliott, Isabel McClellan. Fred Lott, Royden Johnson, Vic Shaw, Sam Stein, Bennett McNeal. Neil Hart man, Robert Guthrie, Elisabeth Anderson. Rachel Harriman, organist.

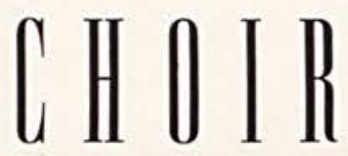

The College Choir has had an active program this year. The thirty-two members and the accompanist, Rachel Harriman, have faithfully rehearsed every Monday evening and sometimes, just before the performance, on Wednesday evening. Their first appearance was on convocation night at the Presbyterian Church at the Men's Bible Reading Contest, and in March at the Women's Bible Reading Contest. The music for the Day of Prayer was provided by the choir. The choir gave several numbers at the musical program at Wilberforce on International Day and at the meeting of the Wilmington District of the Methodist Church in Jamestown in May. On Easter Sunday they sang in the First Presbyterian Church. On Illumination Night they gave a song festival. They topped the year off by singing at the Baccalaureate Services.

The choir was under the direction of Mrs. Mildred Creswell the first semester, and Mrs. Mary C. Markle the second. Everyone, including the members and the audiences, greatly enjoyed the choir.

BEATRICE COLLIER,

Secretary. 
Picture yourself as one-fourth of a quartet. Come around there just a little so your partners and you form a semi-circle. Sound that first word clearly, then let your voice swell in harmony with the lead, hear the other voices blend with yours. Now-sh-make those tones sweet and light, listen to that rumbling bass giving a background to it all. Hear it? Just like the double-bass of a mammoth organ. Low-Throbbing. Take the melody_swing along daintily. Break! Now all is quiet. Start that note exactly with the others. We're coming to the climax. Sing out, let the music roll from way down inside. Now softly run the last few words, linger on the last note-then hum. Let the chord linger-linger-then die.

That was a grand feeling, wasn't it? Whether you were in a barber shop, or on a concert stage you realized you weren't the whole show, but too, you realized the show couldn't have gone on without you. You were there carrying your part of the load, using what you had worked so diligently to learn. You were contributing.

You see how our groups have felt this semester. We have been under the pleasing and instructive leadership of Mrs. Markle, and harmony has been our reward. Harmony of personalities as well as harmony of notes. Our mixed quartet consists of Beatrice McClellan, soprano; Jane Frame, alto; Ray Sisson, tenor; and Sam Stein, bass. The men's quartet is composed of Ted James, first tenor: Ray Sisson, second tenor; Fred Lott, baritone: Sam Stein, bass.

\author{
RAY SISSON \\ Tenor of Both Quartets.
}

MIXED QUARTETTE-Ray Sisson, tenor: Beatrice McClellan, soprano: Jane Frame, alto: Sam Stein, bass.

MEN'S QUARTETTE-Sam Stein, bass; Fred Lott, baritone: Ray Sisson, second tenor: Ted James, first tenor.

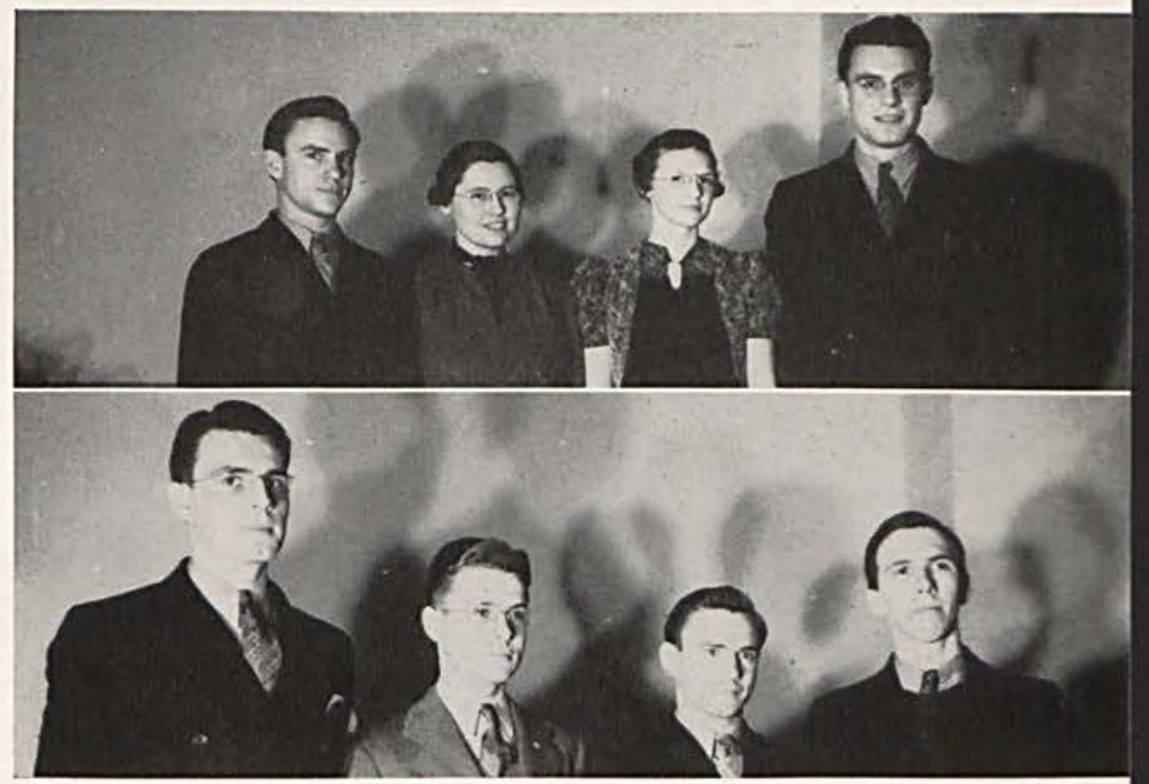


FIRST ROW-Fred Lott, William Lott, Clayton Wiseman, Harold Thomas.

SECOND ROW-Bennett McNeal, Justin Northup, Russel Roberts, Eugene Kavanagh, Robert Reed, Kenneth McNeal.

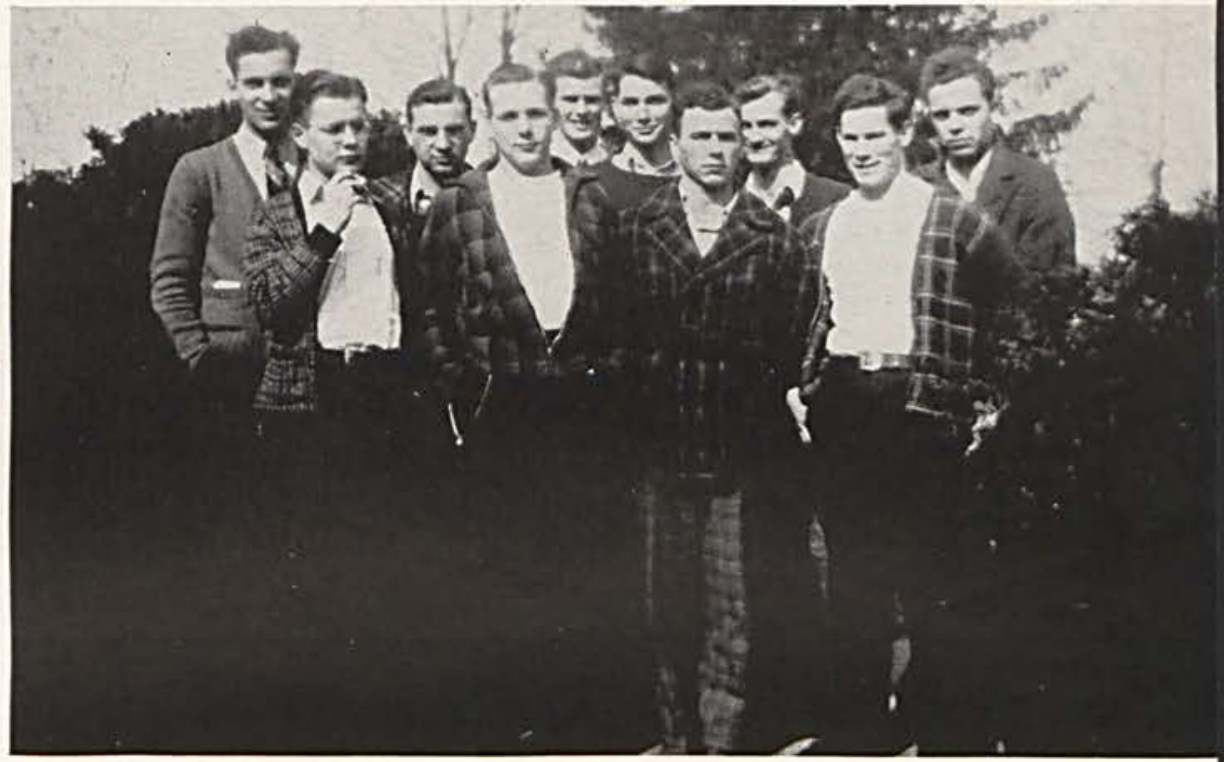

At the election held early in the year, the eloquence of Johnny Peterson won over all opposition and he was duly seated in the presidential chair. Due to a slight disturbance the order of election was altered at this point and Kenny McNeal was chosen Sergeant-at-arms. Brother "Bottle" Benny $\mathrm{McNeal}$ was elected to the grave position of Chaplain and Noah Sharpe as Secretary-Treasurer.

Pledge week came to our attention and the following started on the rocky road to brotherhood: A. Geake, R. Roberts, E. Kavanagh, J. Northup, B. Lott, C. Thomas, H. Thomas, R. Reed and C. Wiseman. Highlights of hell week were Bill Lott's releasing 14 kittens in the library and Puddy Anderson's scramble to rescue her favorite cat; "Tuny" Kavanagh learns to count by having to supply fifty dead flies. Some of the boys were a wee bit sleepy; they showed up for classes still clad in their pajamas. A midnight hamburger fry brought initiation to a close, giving us an opportunity to see Mr. Gibson perform with a hamburger in each hand and a goodly cargo below deck.

Later in the year a box social and dance was sponsored by the frat for all college students.

$$
\begin{aligned}
& \text { NOAH SHARPE, } \\
& \text { Sec'y-Treas. }
\end{aligned}
$$


Under the supervision of Miss Basore and the leadership of the President, Pauline Ferguson, the sorority has flourished this year.

Nine active members took charge of the "Sorority ship" as we embarked on another year in the fall of 1939. Ten pledges have been duly initiated and have become active members of our crew this year.

We have held our regular meetings bi-monthly at Mrs. Ault's. Our meetings have been educational and instructive, as well as social. We have discovered much good talent in our ranks.

We have enjoyed many activities. In October, we enjoyed a "steak fry" at Bryan Farm. In November, Beatrice McClellan entertained the sorority with a delightful dinner party. In December we sponsored a "dinner dance" at Sears Hotel, Cedarville, for alumni members and guests. January was "rush party" time. In February we held "Open House" for alumni members at Homecoming; also Rachel Harriman was hostess for our covered dish supper. March was the scene of our scavenger hunt. April was the setting for our dinner and theater party.

We ended our school year by sponsoring a Spring Formal for the entire college and a party for the alumni during Commencement Week.

We close our year filled with happy memories and hope in years to come that our sorority will mean more to its members through lasting friendships we have gained.

JEAN ELLIOTT,

Secretary.

FIRST ROW-Elisabeth Anderson, Charlotte Turner, Rachel Harriman, Anna Ritenour, Mary E. Edgington, Hazel McClellan, Ruth Stoddard, Orena Marshall, Louise Jacobs, Mary Jean Townsley.

SECOND ROW-Janice Finke Orsadee Stewart, Beatrice Collier, Glenna Basore. Pauline Ferguson, Betty Rowe, Isabel McClellan. Anna Mary McClellan, Beatrice McClellan.

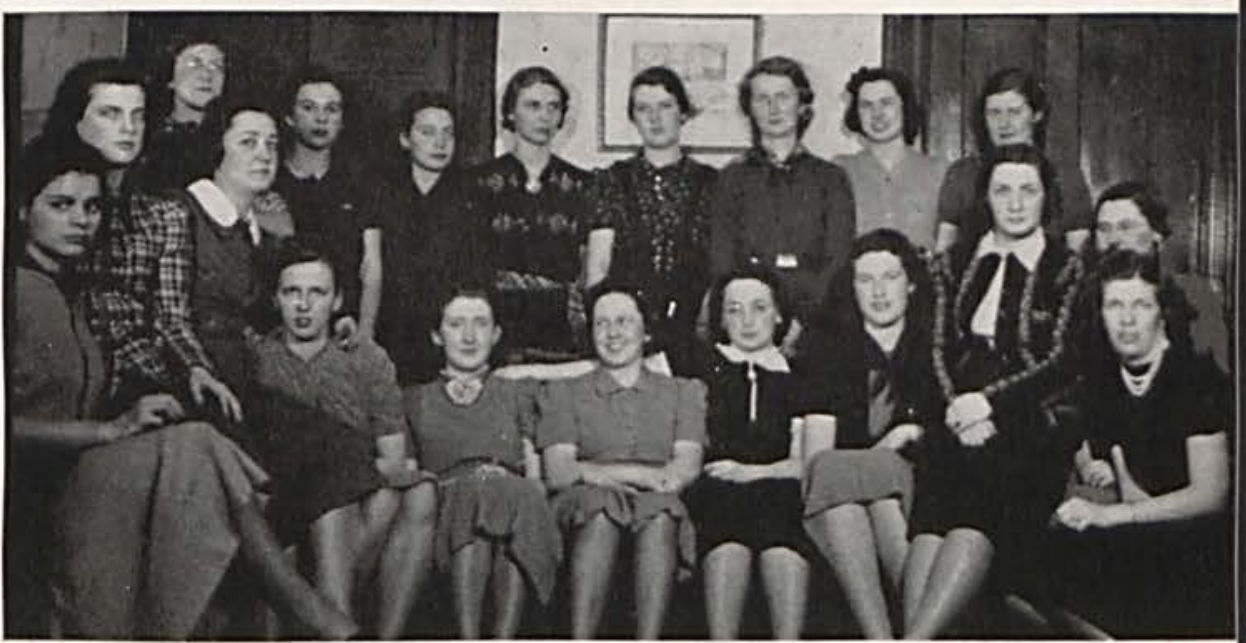


To make their educations complete, the typical man and woman develop the physical side of their lives through participating in athletics. At Cedarville, that function is under the direction of the Physical Education Department. All the students of the college are in this department at some time during their college life.

FRED LOTT,

Sports Editor.

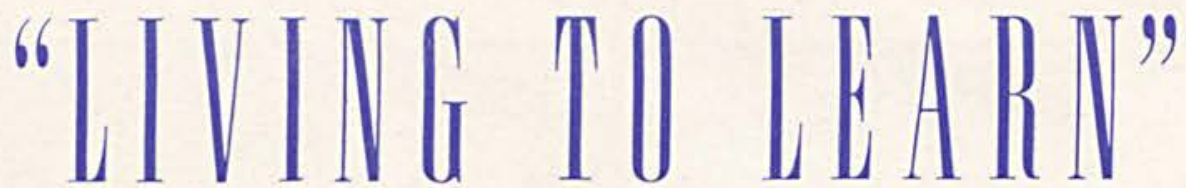




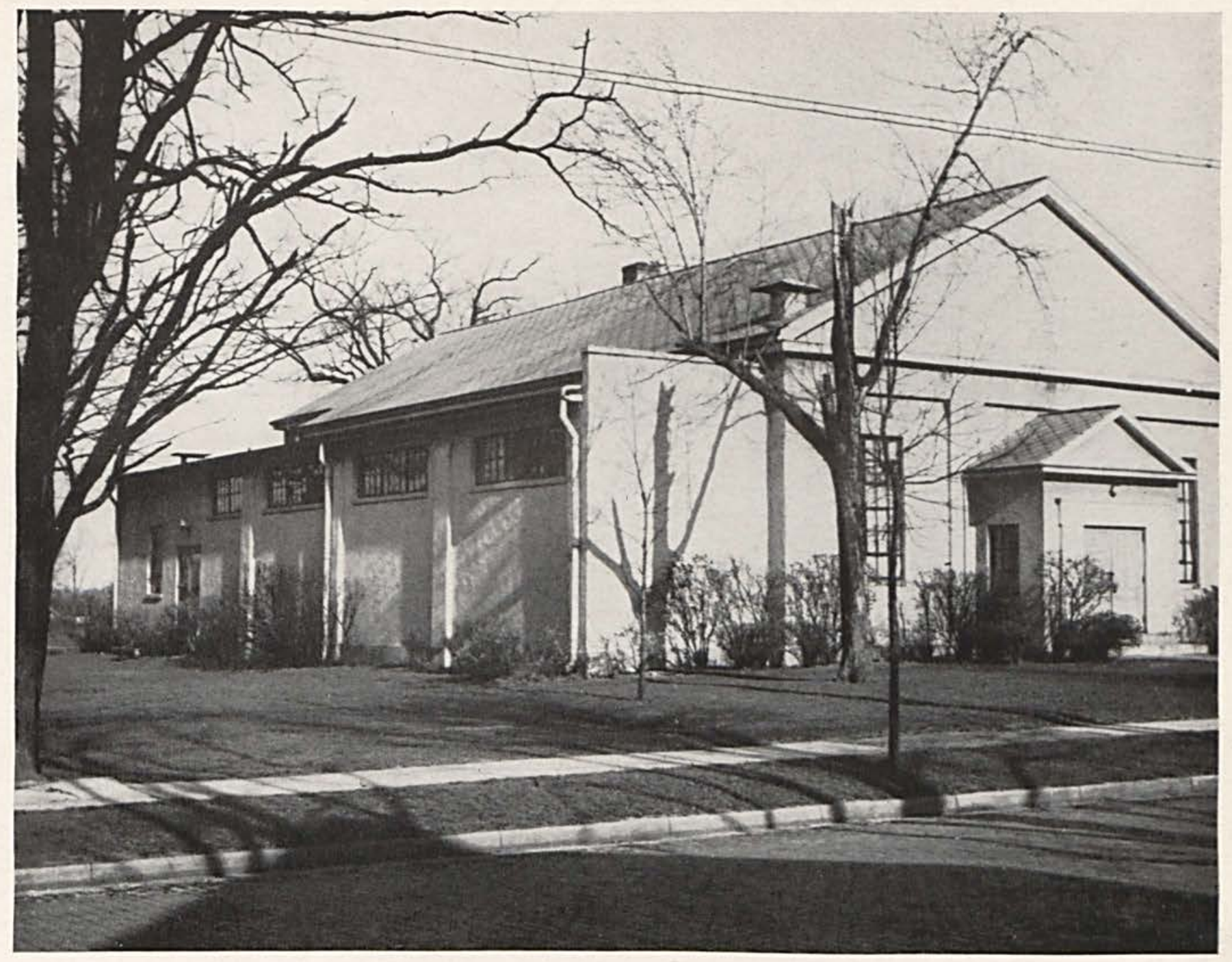

CEARUILE ATHETIS

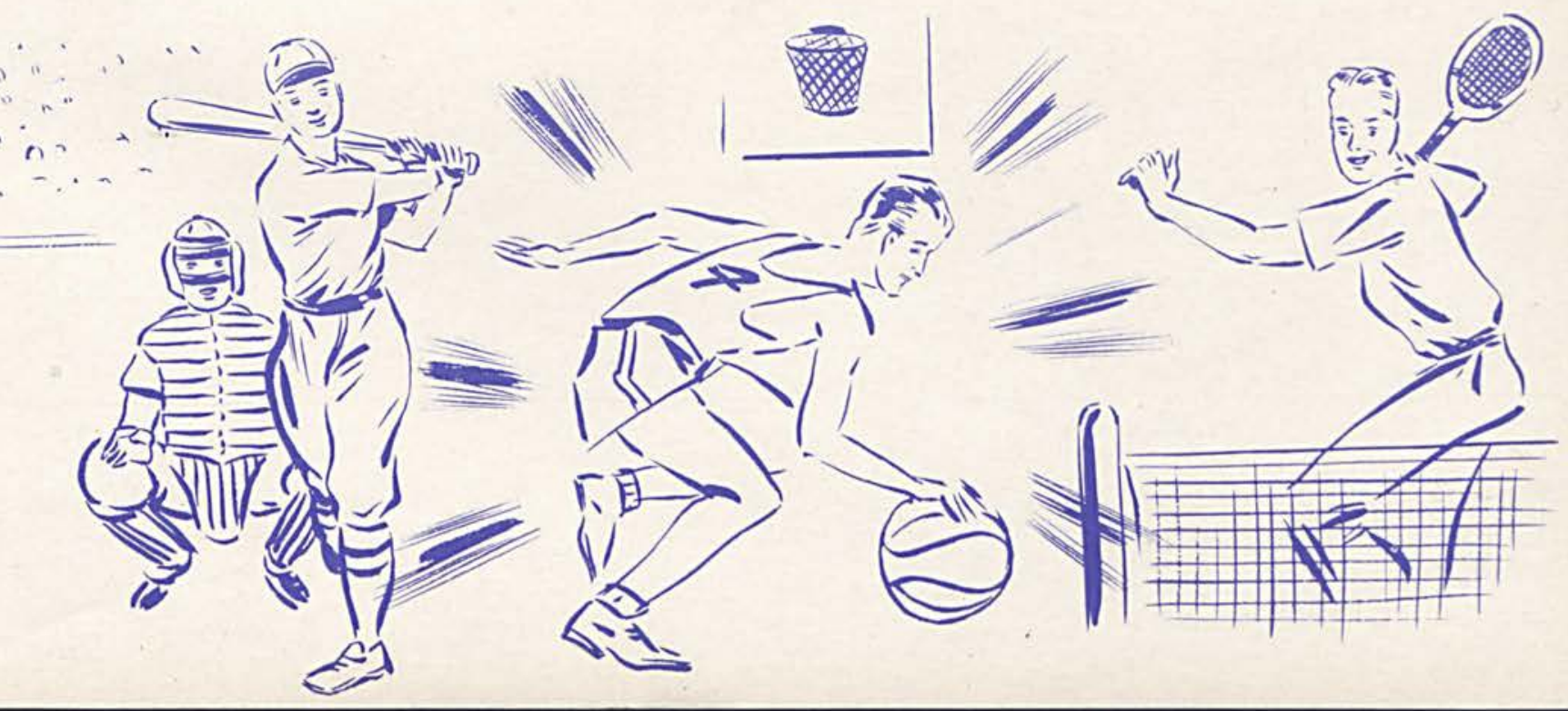




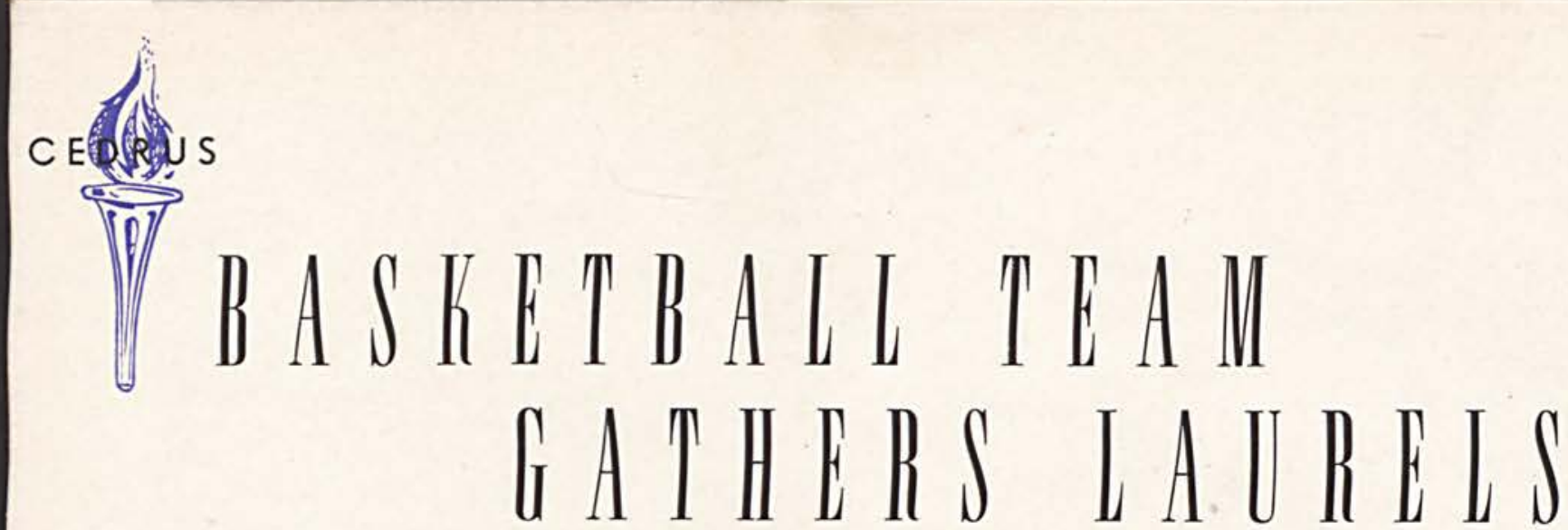

Putting on a driving finish. Cedarville College basketball team won the last five games to take the Northwest Ohio Conference title and end the season with thirteen victories out of an eighteen game schedule.

The boys amassed a grand total of 722 points during the season to earn the nickname of a "point a minute" team. Their opponents collected 631 points for an average of 35 points a game.

There are several reasons for this exceedingly satisfactory record. In the first place, the boys on the team demonstrated a fine spirit throughout the whole season, both toward the members of the opposing team and toward their own team mates. Furthermore, the hard work and undying patience of Coach Miller was a factor without which the team could never have accomplished what they did this year.

Kavanagh was the team's leading scorer with 213 points. Kenneth McNeal, the only senior on the squad at the end of the season, played the outstanding game of his career against Wilberforce, scoring 27 points, when the Yellow Jackets avenged an earlier defeat by Wilberforce and ran up a score of 69-38. On Homecoming day, Cedarville checked a desperate Bluffton rally and emerged victor by a $39-38$ score. In the final game of the season, the Yellow Jackets took the conference title by trouncing Wilmington, traditional rivals, 4I-30. Cedarville played two Ohio Conference teams, winning at Otterbein and losing at Ashland.

FRED LOTT.

FIRST ROW-LaVerne Whipp, Norman Linton, Coach neth McNeal, Russell Roberts, Eugene Kavanagh.

SECOND ROW-Fred Lott, Mgr.. Clyde Walker, Harold Thomas, Sam Stein, Jack Cromwell, Eldon Gillespie, Coach Miller.
FIRST ROW-LaVerne Whipp, Norman Linton, Coach Wiley. William Lott, Justin Northup.

SECOND ROW-Neil Hartman, Richard Macknight, John Reinhard, John Brill, Layden Wilson.
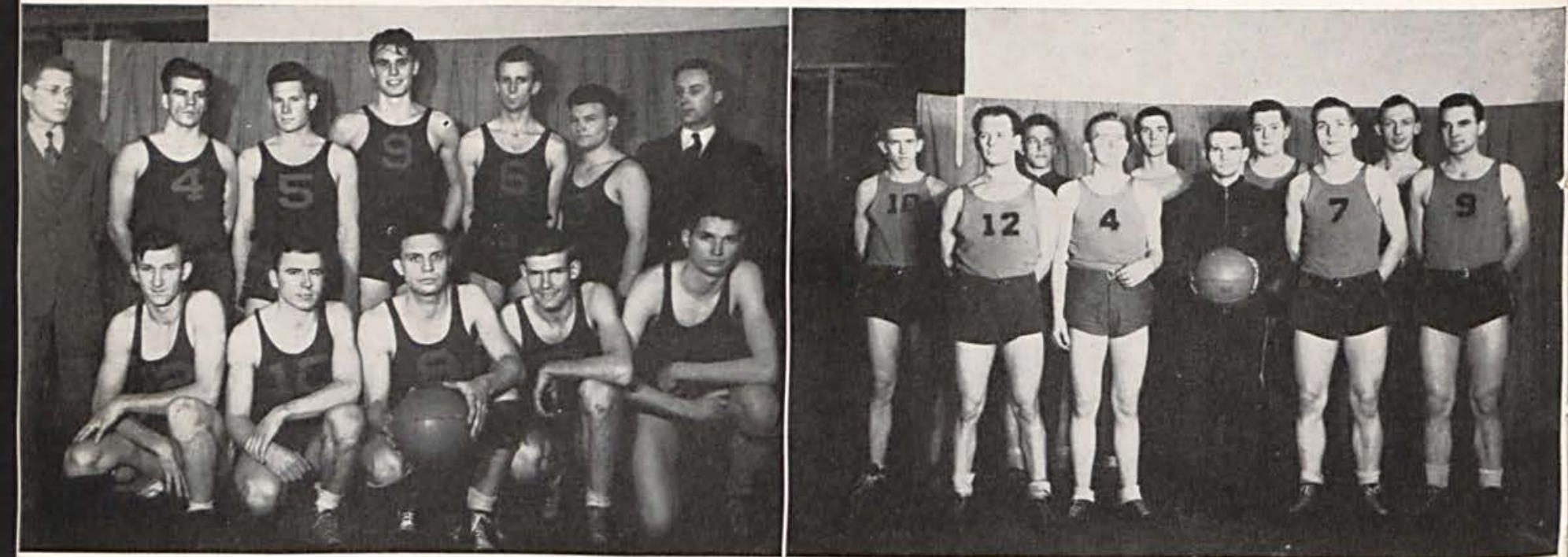


\section{8-39 BASKETBALL SCHEDULE}

Cedarville... 41-Springfield Triangles.... 28

Cedarville.... 35-Holbrook ............ 30

Cedarville... 28-Otterbein ............. 25

Cedarville... 31-Wilmington ......... 41

Cedarville... 38-Wilberforce ........... 48

Cedarville... 37-Springfield Triangles.... 14

Cedarville.... 35-Ashland ............ 59

Cedarville... . 28-Rio Grande............ . 26

Cedarville... 49-Giffin ............. 37

Cedarville... 33-Defiance ............. 22

Cedarville.... 39-Bluffton ............... 38

Cedarville.... 36-Holbrook ............ 42

Cedarville.... 36-Rio Grande............ 43

Cedarville.... 43-Giffin ................ 35

Cedarville... 69-Wilberforce ........... 38

Cedarville... 52-Defiance ............ 31

Cedarville... 51-Bluffton ............. 44

Cedarville... 41-Wilmington .......... 30

\section{Northwest Ohio Conference Standings}

Cedarville

Won Lost

Wilmington ................. $4 \quad 2$

Bluffton .................. $2 \quad 4$

Defiance ................... । 5 30

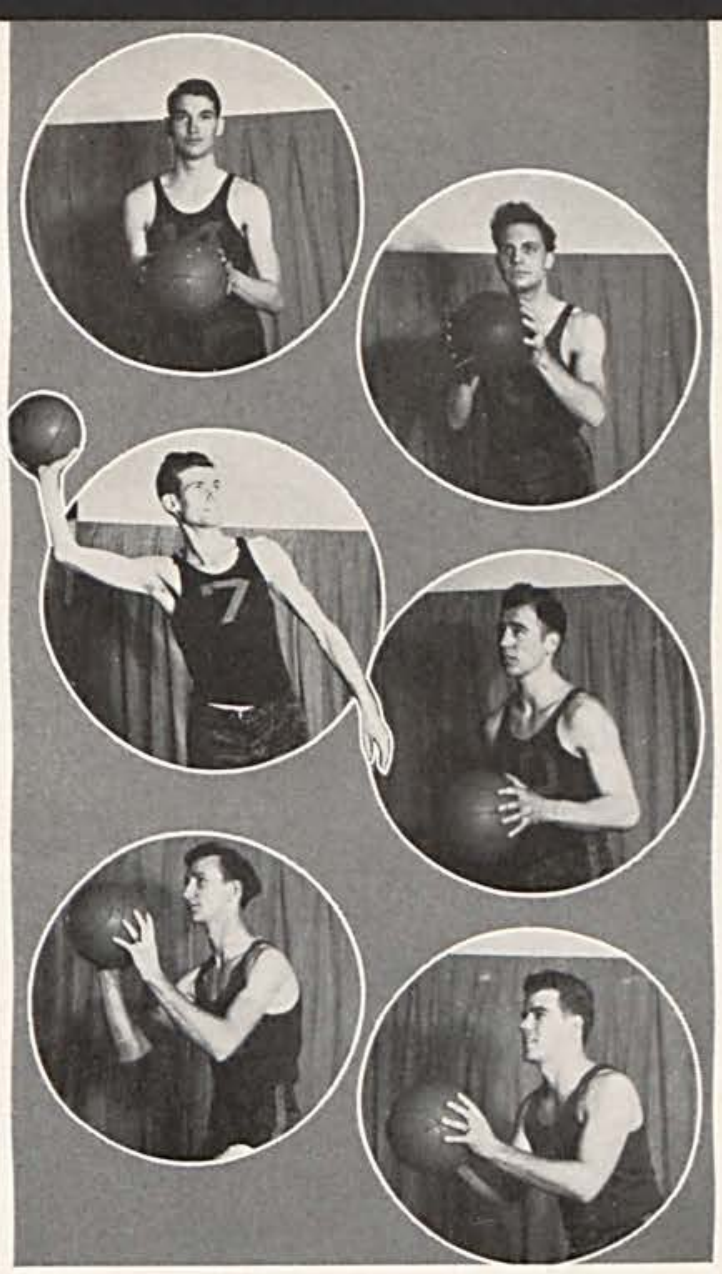

Eugene Kavanagh

Russel Roberts

Clayton Moore

Kenneth McNeal

Clayton Wiseman

Clyde Walker 


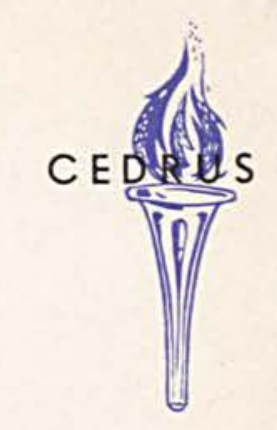

\section{BASEBALL SCHEDULE}

1939

\begin{tabular}{|c|c|c|c|}
\hline April & & Bonebrake & Here \\
\hline & 22 & Rio Grande & Here-Two Games \\
\hline & 29 & Wilberforce & Here \\
\hline May & 4 & Wilmington & There \\
\hline & 6 & Bonebrake & Here \\
\hline & 9 & Urbana. & Here \\
\hline & 13 & Bluffion & There \\
\hline & 17 & Wilberforce & There \\
\hline & 20 & Rio Grande & There-Two Games \\
\hline & 23 & Urbana .. & There \\
\hline & 27 & Bluffion & Here \\
\hline & 31 & Wilmington & Here-Cedar Day \\
\hline
\end{tabular}

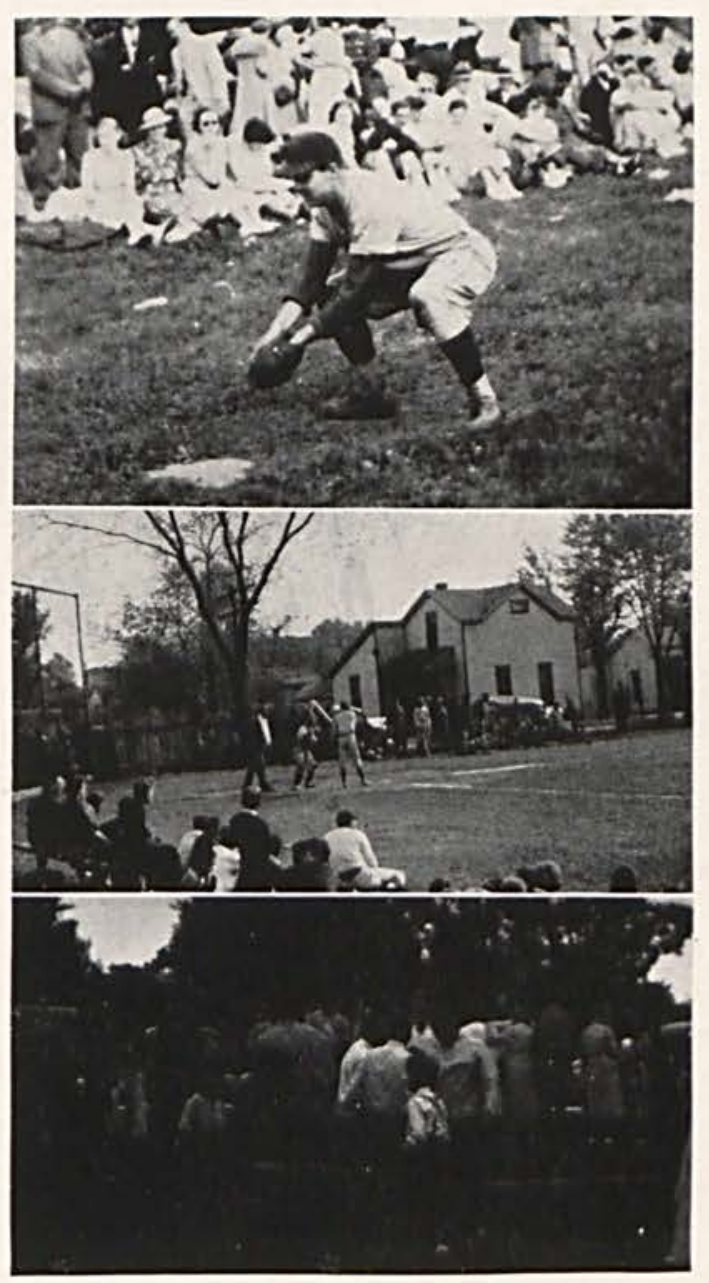



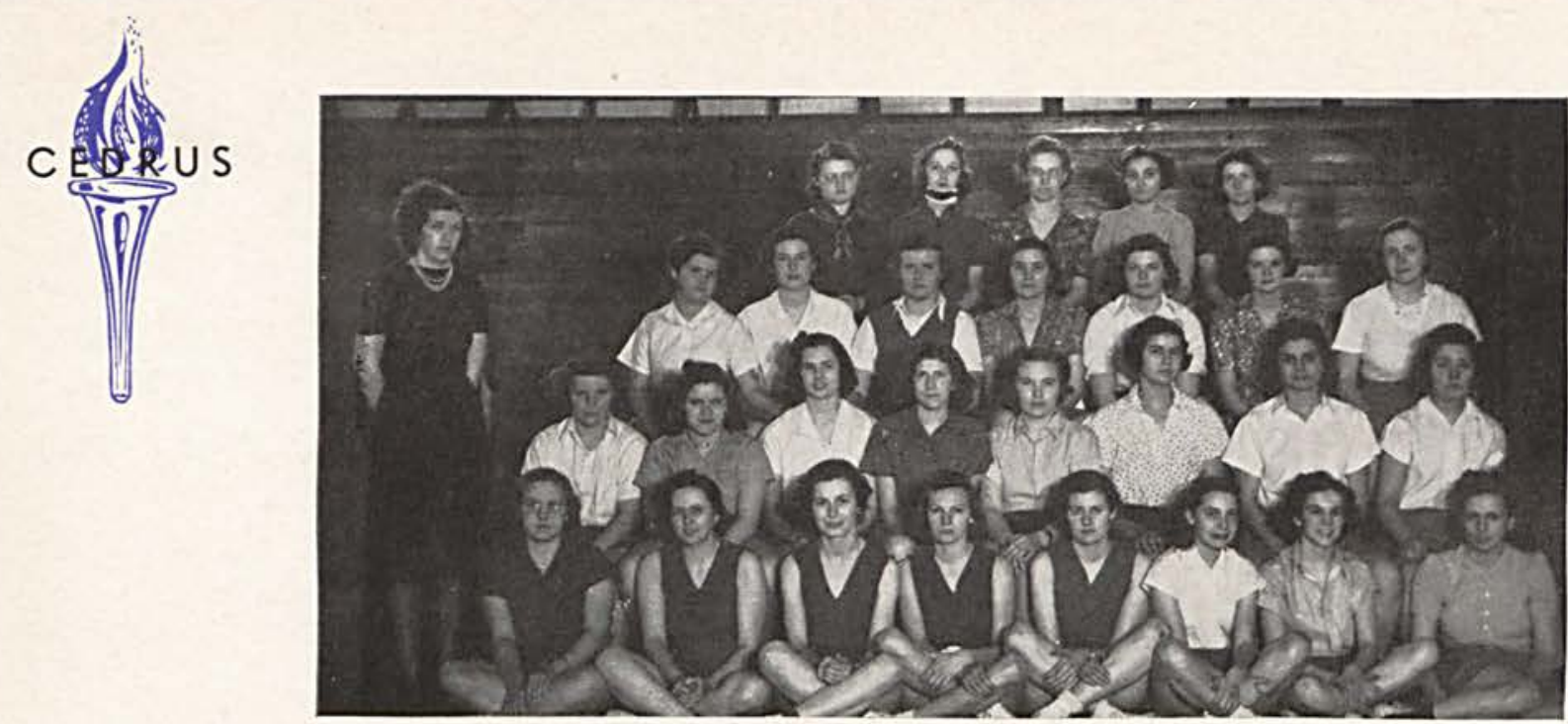

STANDING - Mary Jean Townsley, Instructor.

FIRST ROW-Virginia Lewis, Hazel McClellan, Junia Creswell, Betty Nelson, Anna Mary McClellan, Beatrice Collier, Orsadee Stewart, Ana Louise Ritenour. SECOND ROW-Margaretta Lott, Hazel Bush, Isabel McClellan, Janice Finke Florence Ferguson, Beatrice Gray, Elisabeth Anderson, Rachel Harriman.

THIRD ROW-Helen Chitty, Orena Marshall, Mary Elizabeth Batdorf, Kathrine Randall, Helen Ross, Janette Neal, Marie Collins.

FOURTH ROW-Doris Ramsey, Mae Stebbins, Virgie Gossard, Jean Elliott, Vona Ruth Owens.

As typical American girls we are interested in strong and healthy minds and bodies. For this reason we have participated with enthusiasm in the course in Physical Education under the capable leadership of Mary Jean Townsley.

Tennis courts were of first interest and lively tournaments followed. Folk dancing gave us opportunity to acquire rhythm and poise Plans are being made to demonstrate the results of our efforts on Cedar Day.

We could not have been spectators at the exciting contests of our boys' basketball squad without catching a bit of their fervor, so we spent many lively hours of friendly rivalry in basketball. Volleyball gave less strenuous, but equally spirited exercise.

Spring is in the air and we are looking forward to more hours of combat cver the tennis nets. We will find a champion on our courts.

BEATRICE GRAY. 


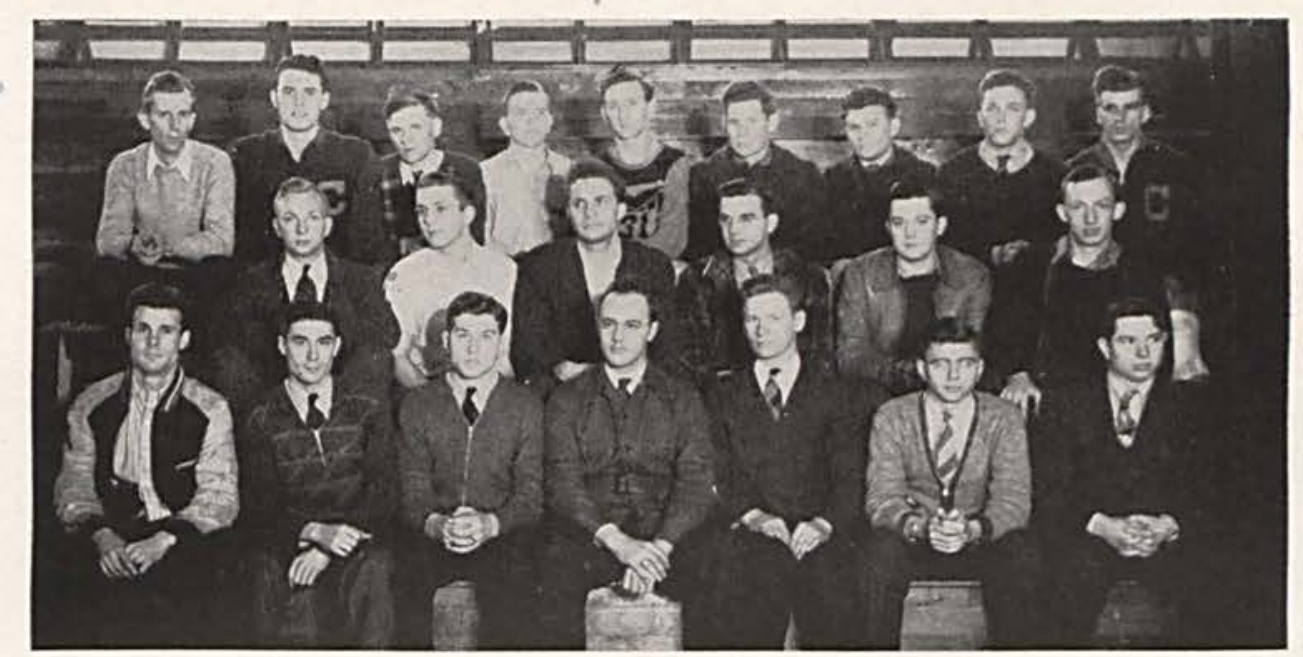

FIRST ROW-James Jackson, Instructor, John Bickett, Fred Little, Robert Sears, Royden Johnson, Robert Guthrie, Roiland Flory.

SECOND ROW-Arthur Geake, William Lott, Kenneth McNeal, Justin Northup, John Brill, Layden Wilson.

THIRD ROW-Jack Cromwell, Sam Stein, Elwood Shaw, Norman Linton, Clayton Moore, Harold Thomas, Eldon Gillespie, Richard Macknight, Clyde Walker.

The Men's Physical Education Department has as its purpose the development of strong bodies and helps give Cedarville students a complete well rounded education.

Early in the year the men enjoyed hard ball as well as soft ball. Soon cooler weather brought into action a most popular sport, football.

Winter sports of volley ball and basketball were well accepted by the men and tumbling was introduced to help build healthier bodies.

This department plays an important role in the entertainment prepared for Cedar Day and here exhibits the results of work done throughout the year.

If our present expectations and plans materialize, the near future will see Cedarville College with a complete and up-to-date physical education department.

\section{JAMES JACKSON}

Men's Phys. Ed. Director. 
To most of us, college life without its social side would be almost unbearable. True, we do appreciate our intellectual thirst and do try to satisfy it, but when we think of balance, it is impossible to overlook the importance of the social side of college life.

Youth is fresh, vigorous, expressive! Youth must act, must laugh, must play. So with enthusiasm the youth of our college joins in the parties, games, dances, courtships and various other extra-curricular activities.

\section{E. CLAYTON WISEMAN, Features Editor}

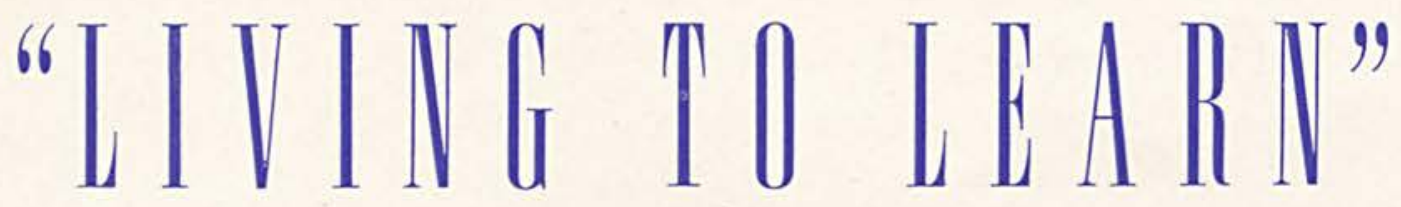




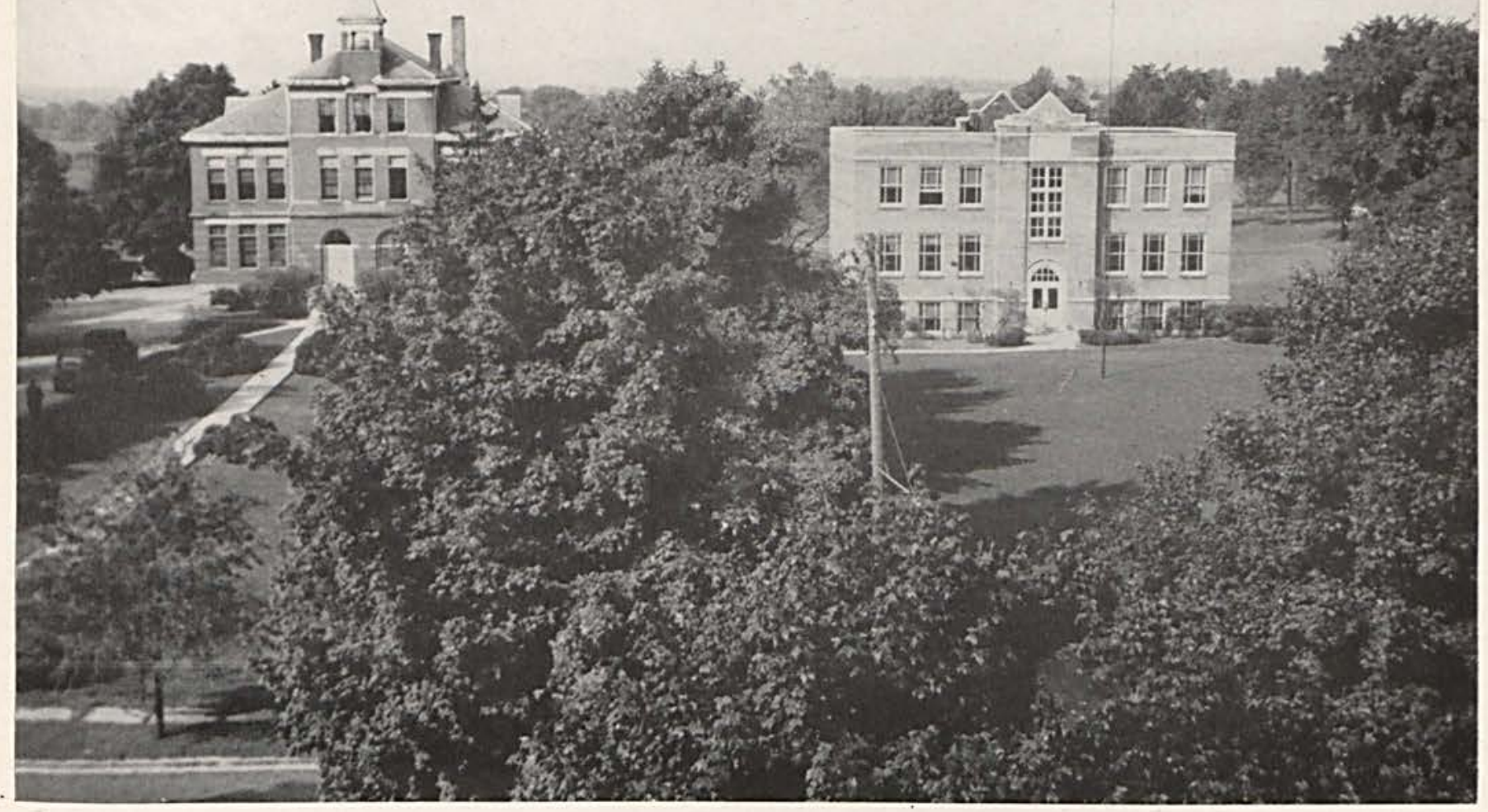

\section{CEAARVILE FEATIRES}

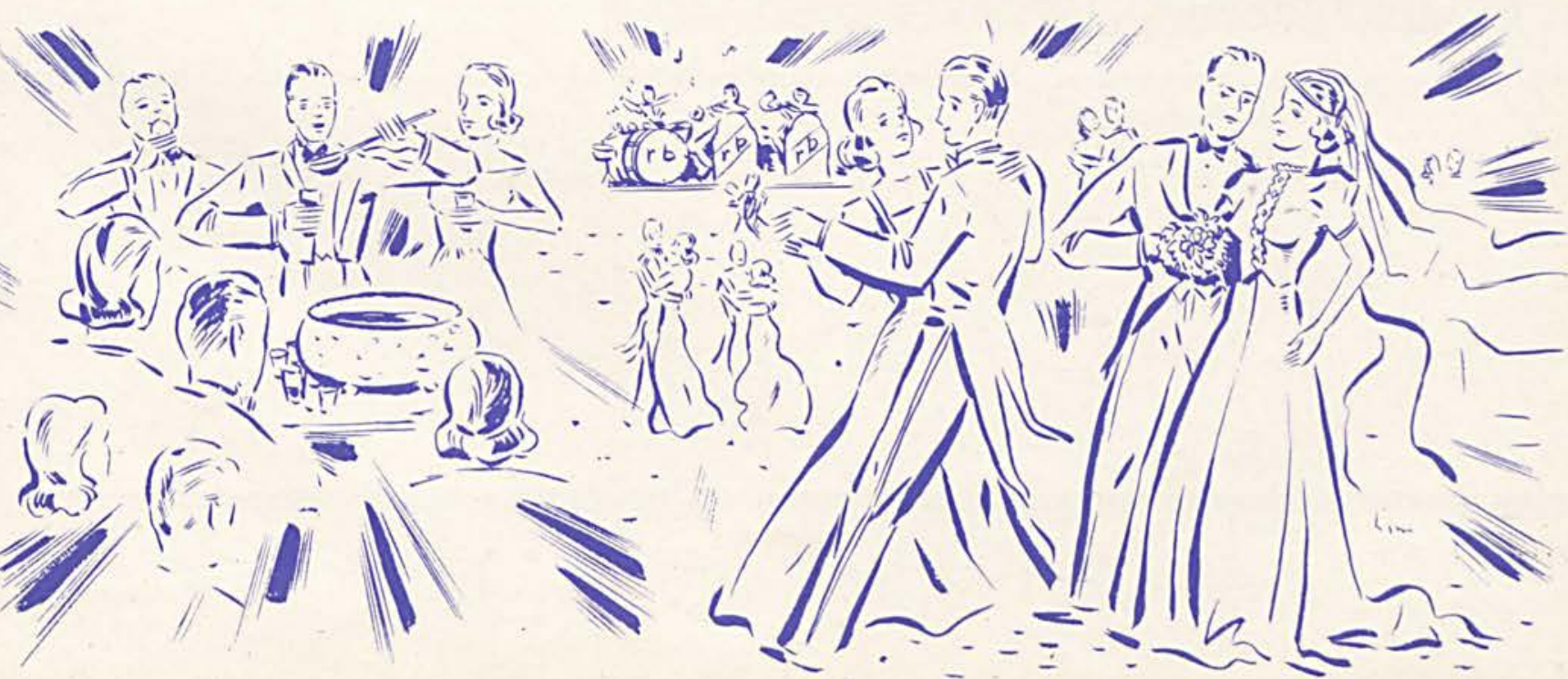




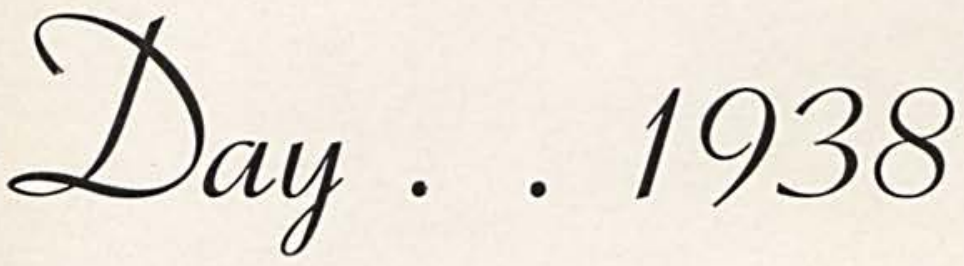

Cedar Day, which is a tradition of the college affords opportunity for the display of pomp and pageantry. The crowning of the Cedar Day Queen is the climax of this gay and colorful occasion. The previous queen leads the processional made up of the new queen and her attendants beautifully and impressively dressed. After the new queen is crowned by the former queen, the annual Cedar Day pageant appears upon the scene. The presentation of the pageant is followed by the Cedar Day Oration. The recessional brings a fitting close to the gala occasion. In 1938 Mary Johnston and Justin Hartman shared honors as Cedar Day Queen and Orator.

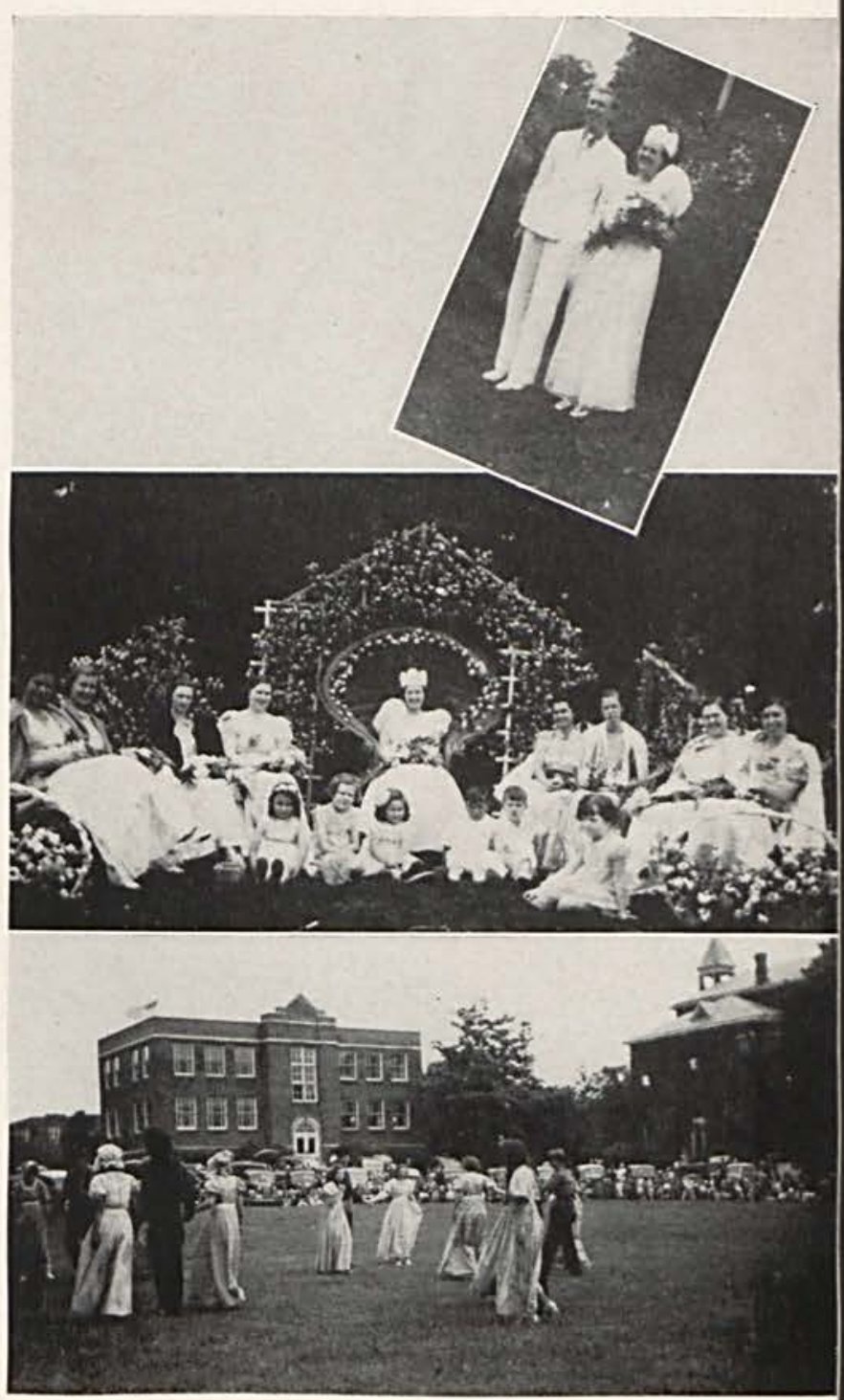




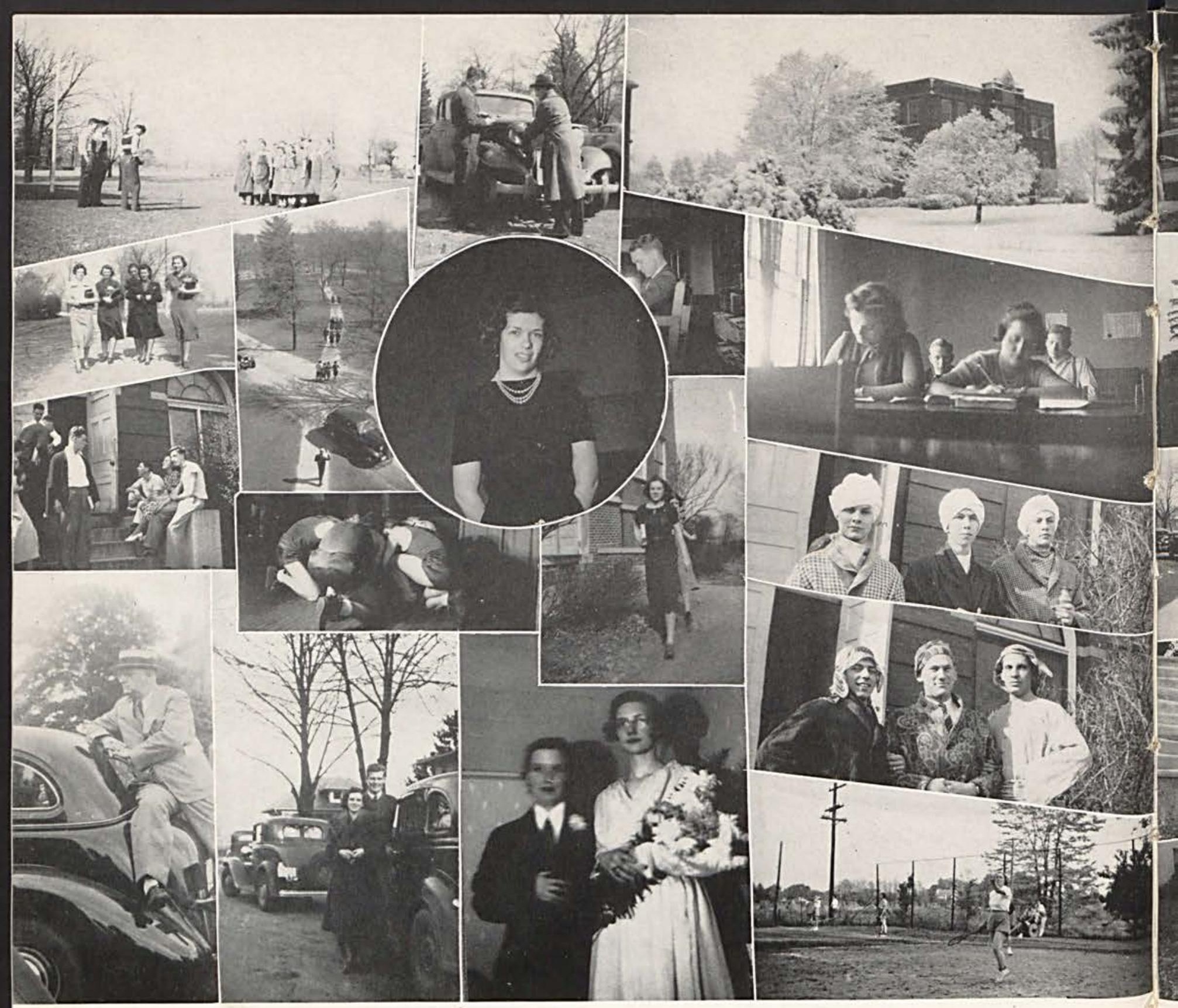

\section{Calendar}

Sept. 7-School opened.

Sept. 8-Presbyterian party. Took stiffness out of freshmen and loosened up the school spirit.

Sept. 12-Y. W. tea at McChesneys'.

Sept. 13-Pajama Parade led by Hartman house. Dibble woke up in Jamestown.

Sept. 20-Boarding club party. Dinner and games. 


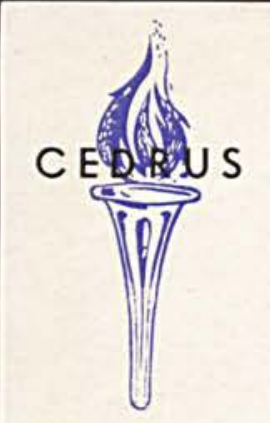

\section{Calendar}

Dec. $15-50 c-50 c$ - who'll pay $60 c-$ shouted the auctioneer. Oh, it's the Frat box supper and dance at the gym.

Dec. 29-Chi Sigma Phi dinner dance at Sears'.

Jan. 7-Beat by Wilberforce in more ways than one. Clyde got hurt.

Jan. 10-Springfield $Y$. foot-er-1 mean basketball game-there. We won.

Jan. 12-First you're up and then you're down. Ashland beat us.

Jan. 14 -Rio Grande-here. We won, but the game was like soup-it was so sloppy.

Jan. 17-19-Woe is us! Exams. Plenty of headaches and no sleep.

Jan. 19-Junior party.

Jan. 20-Music recital in the chapel.

Jan. 23 - An eventful day. We're starting the grind again. Registration day.

Extra!! A reliable source reveals that Clarabelle is married.

Jan. 25-26-Overnight ball trip for the fellows. Played and won at both Giffin and Defiance. Something drastic must have happened in that hotel at Van Wert because the boys haven't been the same since.

Feb. 2-College Day of Prayer. Classes as usual this P. M.

Feb. 3-Boarding club party.

Feb. 4-Homecoming - banquet. game, and dance. Won the game by I point. That's what I say, boys, give the crowd a thrill. Chi Sigma Phi alumni tea.

Feb. 7-Don't look now, but I think someone's broken into the gym. No, it was the Spring Valley-South Charleson game. Varsity Squad went to Holbrook and were defeated.

Feb. 9-Alpha Theta Tau partyeverything went backwards.

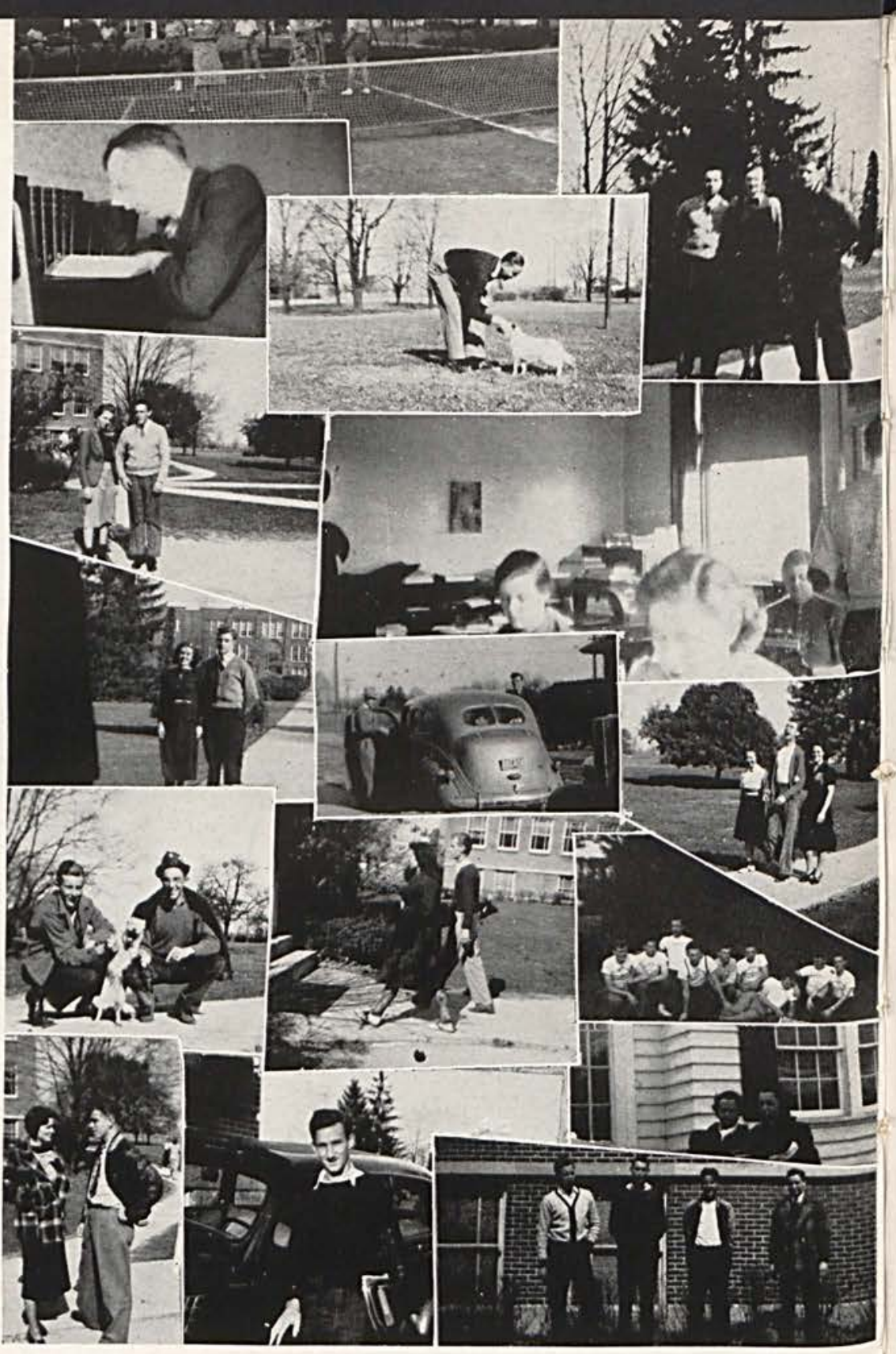

Feb. 10-We're slipping-Rio Grande beat us.

Feb. II-The clouds are clearing, the iinx is beat or something. Trounced Giffin-here.

Feb. 13-International Day at Wilberforce.

Feb. 14-Upset Wilberforce for Clyde's benefit.

Feb. 16-College kids coasted at Knott's.

Feb. 17-Defiance - here. We won again. 
Feb. 21-Bluffton-there. Good game, and we won.

Feb. 28-Chi Sigma Phi covered-dish supper before Wilmington ball game here. We won! This makes us Conference Champions! Team, rah! Team, rah!

March 7-Preliminaries of class tournaments.

Fresh. vs. Juniors-Fresh. on top

Soph. vs. Seniors-Soph. won

March 9-Sophomores won tournament. It has been said, if many more class tournaments were played, Walker wouldn't be the only one on crutches.

Alpha Theta Tau dinner for basketball boys.

March 17-St. Patrick's Day tea-Y. W. C. A. Sophomore Sweater Swing in honor of basketball team. Mr. Eugene Kavanagh crowned king of the affair as most valuable player on the team.

March 2I-College students pick up and sit down at Skateland in Dayton.

March 26 -Girls' Bible-Reading Contest. Irene Goodin - the winner!
March 28-Chi Sigma Phi scavenger hunt.

March 29 to April 4 -Spring vacation.

April 10-Alpha Theta Tau party at Randall's. Jane reveals date for wedding.

April 12-Sophomore skating party.

April 18-Plays given for public by Dramatic Club.

April 20-Chi Sigma Phi party.

April 25-Junior party.

April 28-Y. M. and Y. W. Banquet.

May 5-Chi Sigma Phi formal dance.

May 8-Alpha Theta Tau formal initiation.

May 12-Mother-Daughter Banquet. Senior vacation begins.

May 26 -College Picnic.

May 24-26-Finals. More cramming done.

May 28-Baccalaureate Service.

May 29-Music Recital.

May 3 I-Cedar Day. Ball game.

June I-Alumni banquet.

June 2-Commencement-10 A. M.

ELISABETH ANDERSON.

Diary Editor. 


\section{Y. M. AND Y. W. MIXER}

The Y. M. and Y. W. mixer was the first ali-college party of the year. A program of both round and square dancing was under the able direction of Cecil Thomas and Jeanne Townsley. A college orchestra, directed by Ned Brown, furnished dance music. The gym was beautifully decorated with orange and blue streamers. Light refreshments of ice tea and cookies were served. The fine spirit maintained throughout the evening made this one of the finest parties the college has ever had.

\section{FRESHMAN INITIATION}

The Sophomores took great pleasure in making things as uncomfortable as possible for the Freshmen of '38-'39. During the week of initiation, unwilling and embarrassed "freshies" took their medicine in the form of rides, whacks, foolish make-up, a ducking in willow bend, and conformity to the many requests imposed upon them by upper-classmen.

\section{ALPHA THETA TAU PARTY}

The Alpha Theta Tau Sorority enjoyed a party at the home of the president, Jane Frame, Tuesday night, October 4.

Entertainment and refreshments were arranged by Merieum Foulk and Florence Ferguson. Those who were pledged to membership included D. Ramsey, M. Tobin, H. Chitty, B. Gray, M. Olinger, and B. Carter.

\section{HAY RIDE}

Thursday night, October 6, a hayride sponsored by the Youth Forum of the Methodist Church was held at the Lott farm. A hilarious crowd of forty college students completely filled the two wagons drawn by a tractor. After a long ride flavored with song and laughter, the party was concluded with a wiener roast by the old pond.

\section{SOPHOMORE PARTY}

Friday night, October 7, the Sophomores had a wiener roast at Bryan Farm. About thirty persons were present to enjoy the evening. After gorging on hot dogs, pickles, and marshmallows, all joined in some group games. Moonlight and nippy weather added zest to the fun.

\section{E. PARTY}

Cedarville College students enjoyed themselves at a party Thursday evening, October 13, sponsored by the Epworth League of the Methodist Church. The entertainment was in the form of musical questions and answers patterned after Kay Kaiser's radio program. Musical games and dances were played, and the refreshments were in the form of box lunches.

\section{"FRAT" PLEDGES ACCEPTED}

The pledges of the Delta Kappa Sigma Fraternity finished their formal initiation Friday night, October 14. After a few hours of climbing, walking, and crawling they returned to the gym with the long lost paddle only to have it properly applied to their-anatomy. Several old members were present and after the pledges were all formally accepted, a feed of hamburgers, cocoa and cookies was enjoyed by all.

Mr. Gibson, faculty adviser for the Fraternity, was invited and formally accepted as an honorary member. 


\section{HALLOWEEN DANCE}

The Y.W.C.A. sponsored a lively evening of entertainment Friday night, October 21 at the gym. About sixty persons turned out and enjoyed the dancing. Ned Brown furnished the music. The masquerade part of the dance didn't turn out as well as had been expected; however, Jane Frame and Opal Seamon gave the spectators several hearty laughs with their costumes.

Delicious refreshments of cider and pumpkin pie were served.

\section{FRESHMAN PARTY}

The Freshman held a party at Lott's farm on Tuesday night, October 25. About twenty freshmen attended, but the crowd was swelled by the representatives of upper-classmen. The earlier part of the evening was spent in roasting wieners and playing games. Later most of the party returned to town and danced at the Republican Rally.

\section{U. P. PARTY}

The Election Party given by the Young People of the U. P. church for the student body Tuesday evening was a great success.

The party room was attractively decorated in red, white and blue with a voting precinct at each end. Ballots were cast for the brainiest, most sociable, most chic, and other "political offices."

A unique style show was presented by the men and girls present. The men dressed their girls in newspaper costumes and paraded with them before the judges. Refreshments were in the form of cider and cake.

\section{CONGRATULATIONS}

Cedarville College students and faculty are proud that Greene County has again chosen its president Dr. W. R. McChesney for Representative to the state legislature.

\section{COMMITTAL SERVICE}

The Cedarville College Y.W.C.A. held its annual Committal Service Tuesday evening, November 22 in the First Presbyterian Church of Cedarville. This impressive candle-light service serves two purposes. It is an installation service for the officers for '38-'39, and it welcomes the freshmen women into the Y.W. orgenization. The Committal Service is presented in memory of Miss Frances McChesney, who was the daughter of the president of Cedarville College, Dr. W. R. McChesney, and the author of the service.

\section{WIN OVER HOLBROOK}

Cedarville College's flashy combine tramped over Holbrook College to the score of 35 to 30 . Gene Kavanagh led the scoring with 15 points for Cedarville. 


\section{GOOGENHEIMER-HORNSWOGGLE NUPTIALS}

In a beautiful ceremony performed at the home of Miss Mary Jean Townsley, Friday evening, December 2, Miss Susabella Googenheimer (Jane Frame) became the bride of Mr. Obadiah Hornswoggle (Beatrice McClellan). The ceremony was performed by Mr. J. Tweedle, D.D. (Arema Hayes). The wedding march "She'll Be Coming 'round the Mountain," was played by Rachel Harriman.

Other members of the bridal party were: maid of honor, M. Collins; bridesmaids, J. Neal and G. Bickett; best man, P. Ferguson; ushers, M. J. Townsley and E. Anderson; flower girl, D. Kennon; ring bearer, B. Gray.

\section{SECRET PAL PARTY}

The girls of Cedarville College held their Secret Pal party Monday evening, December 12, 1938 at the home of Jane Frame.

Various contests and the singing of Christmas carols afforded entertainment. Following this came the fun of distributing and opening gifts. Delicious refreshments concluded a most delightful evening.

\section{STAR PLAYERS}

Mr. Fred Lott and Mr. Neil Hartman starred in the plays presented by the dramatics club under the direction of Miss Basore Tuesday night. December 13. In "A Sign Unto You" Fred very ably played the role of a young minister. Neil starred in his portrayal of the tramp in "Dust of the Road."

A capacity audience witnessed the successful plays.

\section{WILMINGTON TRIUMPHS}

The Yellow Jackets took their first defeat at the hands of Wilmington College, Wednesday evening. December 14. The boys took an early lead but were soon overcome and finally beaten by a score of 42-31. This was the first defeat of the season and the score stood with three won and one lost.

\section{CHI SIGMA PHI DINNER PARTY}

The Chi Sigma Phi sorority had a dinner dance at the Sears Hotel in Cedarville Thursday evening. December 29. After a delicious dinner was served, the girls adjourned to another room where the two pledges, Mary E. Edgington and Orena Marshall were formally initiated into the sorority.

Following this the members, alumni, and guests were entertained by dancing and social games for the remainder of the evening.

\section{CEDARVILLE LOSES}

Saturday night, January 7, the Yellow Jackets played Wilberforce on the latter's court. In the preliminary game the Cedarville Reserves defeated the Wilberforce Reserves 27-16.

The varsity squad had tough luck losing the game 49.38 and losing one of our best players, Clyde Walker, who received a serious knee injury during the game. 


\section{WIN TWO ON OVERNIGHT TRIP}

Cedarville's Yellow Jackets chalked up two straight wins on their overnight trip. They downed a fighting Giffin quintet by a score of 49-37. McNeal, Kavanagh, and Roberts led the scoring with 17, 11 and 12 points respectively.

At Defiance the boys experienced little difficulty in overcoming their opponents by a score of 33-23. Kavanagh led with 14 points.

\section{DAY OF PRAYER}

The members of the faculty and student body attended an impressive service at the Presbyterian church, Thursday, February 2.

The college choir sang two beautiful numbers. Sam Stein sang "The Lost Chord." Dr. McChesney presided. The sermon was delivered by Dr. Hugh I. Evans, of Dayton, Ohio. He gave an inspiring and impressive address calling our attention to the need of prayer in our lives. He advised youth to use prayer as a means of guidance, inspiration, and strength.

We are grateful for the privilege of hearing such men as Dr. Evans.

\section{HOMECOMING BANQUET}

A capacity crowd enjoyed one of the finest Homecoming Banquets in the history of the college. Alumni, students, faculty, and friends joined together with zest in the partaking of a delicious meal. Afterwards speeches from various men of prominence and group singing kept up the spirit of the gala occasion. Dr. McChesney, acting as toastmaster, added to the occasion with his congenial remarks and sincere praise. The college mixed quartet favored the group with several melodies.

\section{HOMECOMING GAME}

Before the largest homecoming crowd for many a year Cedarville defeated a strong Bluffton team by the close margin of 39-38.

K. McNeal started the scoring for Cedarville with a beautiful shot from the foul circle. After this Cedarville maintained the lead throughout the game.

Scoring honors went to C. Wiseman with 13 markers and R. Roberts and K. McNeal with II points each.

Kavanagh and Roberts showed unusually defensive work on the bank boards while Brown played his usual steady game of good ball-handling and passwork at guard.

\section{INTERNATIONAL DAY}

Cedarville College participated in the International Day musical program at Wilberforce U. Monday night, February 12. The mixed chorus presented two numbers and Ted James sang a solo. Antioch College was represented by two soloists.

The famous Wilberforce Singers sang several spirituals and a quartet presented an operatic number. Everyone was impressed by the beauty and harmony of the singing by the Wilberforce Singers. 


\section{CEDARVILLE TRIMS WILBERFORCE}

In a very impressive but one-sided victory, Cedarville revenged an earlier defeat by trimming Wilberforce $U$. to the tune of 68-38.

The Yellow Jackets led at the half-way mark by 13 points.

Kenny McNeal starred by scoring 27 markers to top Cedarville's scoring. Kavanagh followed close with 20 points. Roberts played a splendid defensive game, but managed to connect for only 8 points. From the bleachers the highlights of the ball game were those beautiful long shots by Wiseman who scored 10 points from the center of the floor and those spectacular passes by Ned Brown.

\section{MEN'S BIBLE READING}

The annual Men's Bible Reading Contest was held in the Presbyterian church Sunday evening, November 13. Winners of this year's contest were: first, Ned Brown; second. Neil Hartman; third, Ray Sisson; fourth, Royden Johnson; and fifth. Orval Labig. Dr. Ritchie of Cedarville, returned U. P. minister, donated the money for this contest.

Special music was furnished by the college choir under the direction of Mrs. M. W. Creswell.

\section{COASTING PARTY}

Twenty-three members of the student body, most of them Sophomores, enjoyed a coasting party at the Knott farm Thursday night. February 22. A large fire, built on top of the long hill, served to thaw out frozen fingers and toes. After two hours of fun and frolic the party adjourned to the cozy farm home and enjoyed hot drinks and hot dogs galore. The remainder of the evening was spent playing games, talking and laughing.

\section{CEDARVILLE DRUBS DEFIANCE}

The Yellow Jackets went on a spree to defeat Defiance here by a score of 52-31. Cedarville led at the half by a score of 26-16.

K. McNeal contributed 21 points to the cause to lead Cedarville's scoring. Closely following McNeal was Kavanagh with 16 points.

\section{CEDARVILLE TROUNCES BLUFFTON}

Cedarville defeated Bluffton on the latter's floor 51-44. It marks their 12th win in 17 starts and their 4 th win out of 5 starts in the N.W.O.C.

Wiseman started the team off with his famous one-handed shot and Cedarville was never headed from this point.

Kavanagh and Roberts were in good form and scored 18 and 13 points respectively. McNeal and Brown showed good defensive play throughout the game.

\section{CEDARVILLE TRIMS WILMINGTON TO BECOME CHAMPS!}

Before a near capacity crowd the Cedarville Yellow Jackets defeated the Wilmington Quakers to carry off the championship laurels of the N.W.O.C.

This win climaxed a successful season of 13 wins out of 18 starts.

E. Kavanagh, high scorer for Cedarville, led the attack with 16 points, followed by $\mathrm{McNeal}$ with 9 and Roberts with 8 points.

Wiseman and Brown showed veteran ability in holding down their guard positions.

Cedarville maintained her point-a-minute record which she has established this season by defeating the Quakers 41-30. 


\section{QUEEN AND ORATOR}

Miss Jane Frame, Cedarville, was chosen Cedar Day Queen at an election held by the student body. John N. Fox, Dayton, was elected Cedar Day Orator at the same election.

\section{ALPHA THETA TAU PARTY}

The Alpha Theta Tau Sorority gave the B. B. boys a fine supper and evening of fun Thursday evening. March 9, at the home of Miss Jane Frame.

After supper the guests enjoyed various games from "pick up sticks" to "animal." All in all the boys had a fine time and said quite sincerely "thanks a lot for a good evening of fun, girls."

\section{SOPHOMORES ARE CHAMPS}

The Sophomore class took the championship of the intramural B. B. tourney by defeating the Freshmen in the finals to the tune of 58-39.

\section{SOPHOMORE SWEATER SWING}

A majority of the student body and several members of the faculty turned out and engaged in an evening of dancing Friday night, March 17. Ned Brown furnished the music and all enjoyed "swinging" to his rhythmic music. Punch was served at the intermission.

The gym was beautifully decorated in green and white.

\section{PRESENTED PLAY}

The cast of "Dust of the Road" presented the play at Columbus in the State Religious Drama Festival Saturday, March 25.

Miss Basore directed the play. The cast included N. Hartman, O. Labig, H. McClellan, and C. Wiseman.

The critics gave special notice to the performance of N. Hartman, praising him highly in his portrayal of the Tramp.

\section{Y. W. TEA}

Friday afternoon, March 17, the Y. W. gave a St. Patrick's Day Tea in the gym. The gym was attractively decorated in green and white.

An attractive luncheon was served to approximately 75 guests.

A musical program was enjoyed by the guests throughout the afternoon.

Jean Elliott was general chairman, assisted by Elisabeth Anderson, social chairman, and Marie Collins, decoration chairman.

\section{WOMEN'S BIBLE READING}

Sunday evening. March 26, the annual Women's Bible Reading Contest was held in the Presbyterian Church. The winners of the contest were: first, Irene Goodin: second, Junia Creswell; third, Doris Ramsey; fourth, Isabel McClellan; and fifth, Grace Bickett.

Miss Margaret Rife, of Xenia, donated the prize money for this contest.

The College Choir, under the direction of Mrs. David Markle, furnished special music for this event. The Men's Quartet also favored the congregation with some well rendered special numbers.

\section{E. CLAYTON WISEMAN \\ Features Editor.}




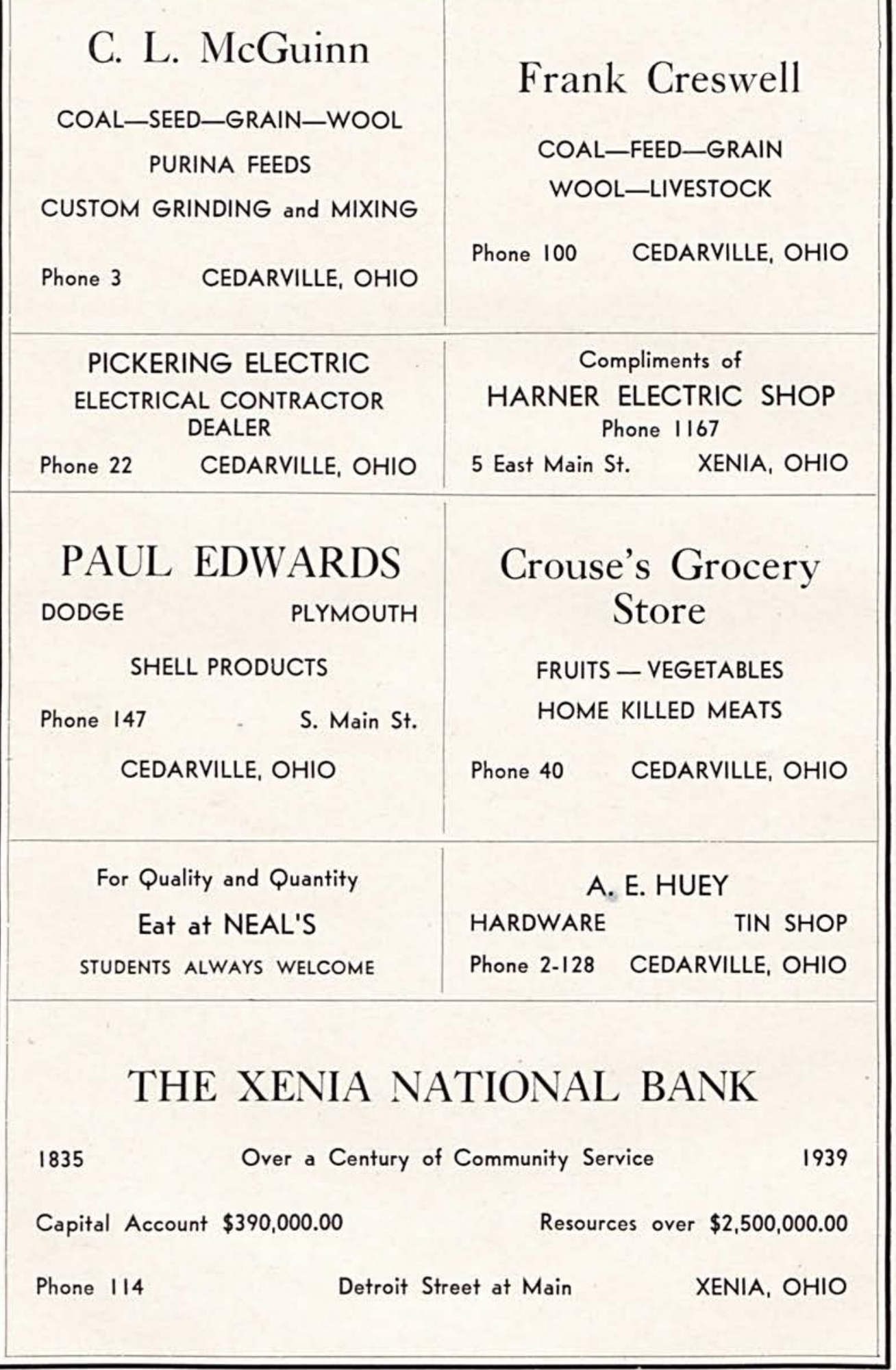


RECO SPORTING GOODS FOR BOYS AND GIRLS

\section{THE RECO STORE}

BASEBALL-SOFTBALL-TENNIS-GOLF-RACKETS RESTRUNG FISHING TACKLE

16 W. High St.

SPRINGFIELD, OHIO

Covault's Beauty Shop

EVERY BEAUTY SERVICE

Phone 434 XENIA, OHIO

Phone 104 CEDARVILLE, OHIO

\section{Nagley's Grocery}

"THE CORNER STORE"

L. H. KOHL

EDNA B. KOHL

\section{Old Mill Camp}

SPECIAL DINNERS

SANDWICHES

CABINS

34-36-38 West Main St.

Phone 4

XENIA, OHIO
S. R. 42 CEDARVILLE, OHIO

\section{THE CEDARVILLE HERALD}

Commercial

Catalog

Let us give you an estimate

on your printing 


\section{Hilltop Greenhouses}

H. C. FENCKER

Phone 31 JAMESTOWN, OHIO

FLOWERS FOR ALL OCCASIONS

Sear's Restaurant and Hotel GOOD FOOD AND POPULAR PRICES

Phone 99 CEDARVILLE, OHIO

C. E. MASTERS

GROCERY AND MEAT MARKET

Phone 44 CEDARVILLE, OHIO

\begin{tabular}{|c|c|}
\hline & \\
ICE SERVICE \\
Evans & Restaurant \\
Phone 58 & CEDARVILLE, OHIO
\end{tabular}

\section{GIBNEY'S}

Ladies Ready to Wear

XENIA, OHIO
Compliments of

The Cozy Theatre CEDARVILLE, OHIO

LEO ANDERSON, D. V. M. VETERINARIAN

Phone 81-R2 CEDARVILLE, OHIO

\section{BROWN'S DRUGS}

The Rexall Store

The Best in Drug Store Service

Visit our Fountain

Main St. CEDARVILLE, OHIO

EVANS RESTAURANT

LUNCHES AND SHORT ORDERS

Phone 58 Xenia Ave. CEDARVILLE, OHIO

\section{Hamman's Dairy}

Milk

Single and Whipping Cream

Phone 197-R3 CEDARVILLE, O. 
To the Readers of the 1939 Cedrus:

The 1939 Cedrus has been published to present every aspect of college life at Cedarville and to remind all those in any way connected with this institution that by being a part of this organization they have accepted a responsibility toward everyone they contact. This responsibility has been established by the activities of students, graduates, and faculty members who are influential in many localities and in all walks of life.

The publication of this book has been made possible by the cooperation of numerous individuals who are vitally interested in the future welfare of $\mathrm{Ce}_{e}$. darville College. We want to take this opportunity to express our appreciation of their efforts. Mr. William Freund, representative of the Pontiac Engraving Co., is largely responsible for the organization of this edition. We want to thank Russell Roberts, assistant editor and advertising manager, and John Fox for their efforts in obtaining advertisements. Marie Collins and Beatrice McClellan, typists, have been very faithful in getting copy ready for the printer. We want to thank Clyde Walker for his help with the art work and Mary Jean Townsley who has taken care of the snapshots. Throughout the Cedrus you have read articles written by various students and faculty members. For these we are grateful. In addition to the articles written by Jane Frame, organizations editor, we wish to thank her for her ceaseless efforts in helping direct the activity necessary in presenting this Cedrus. We wish to thank the following organizations for their cooperation in helping make this book a success: Wren's Studio, Smith-Malloy Cover Co., Pontiac Engraving Co., and The F. J. Heer Printing Co.

It is our wish that in the years to come as you look at this Cedrus you will be reminded of the many pleasant experiences you had at Cedarville and will be inspired to continue living the fuller life that Cedarville College inspired by its intellectual, spiritual, social, and physical training.

Sincerely,

BENNETT MCNEAL.

Editor. 


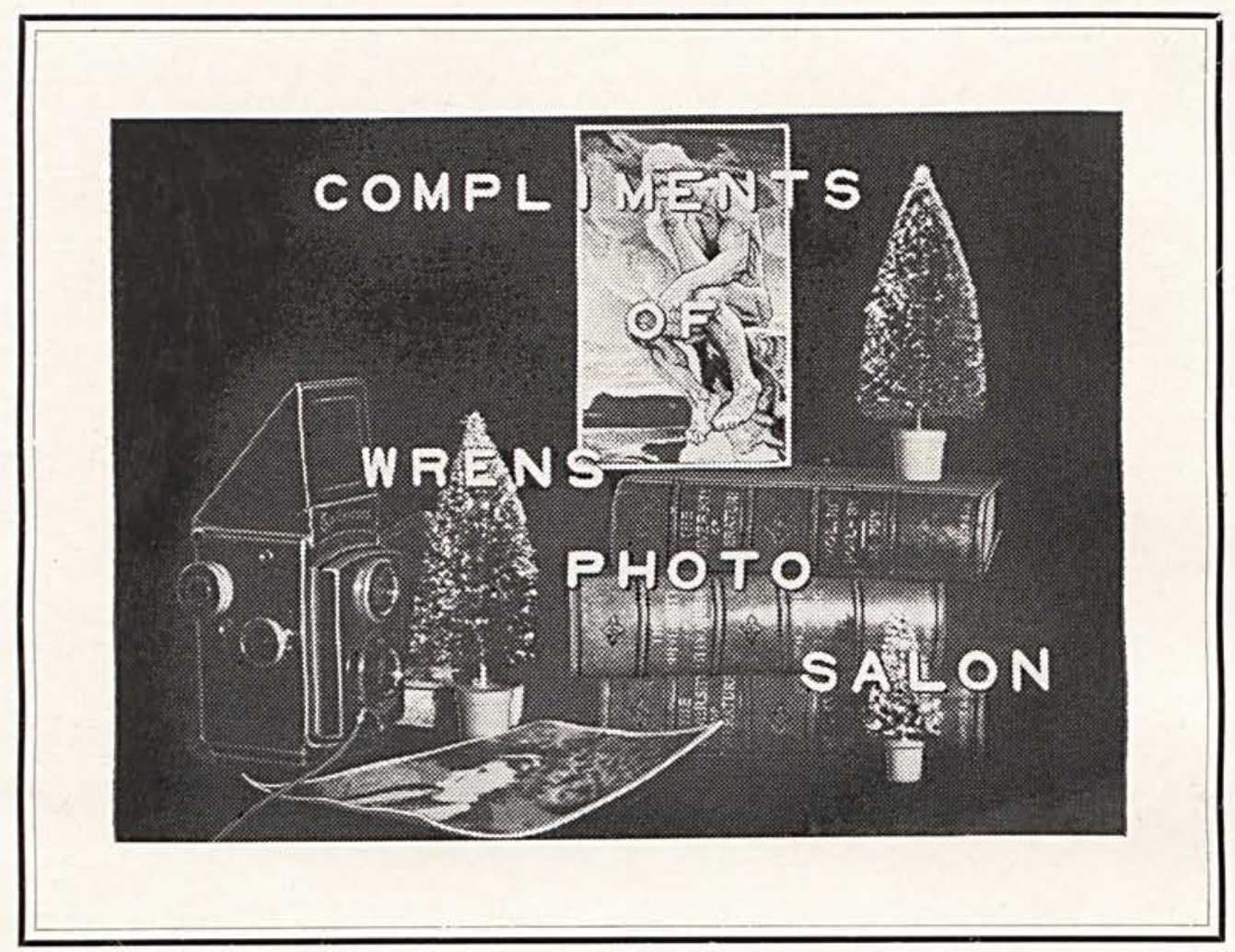

\begin{tabular}{|c|c|}
\hline $\begin{array}{c}\text { Compliments of } \\
\text { SHANE'S BARBER } \\
\text { SHOP } \\
\text { CEDARVILLE, OHIO }\end{array}$ & $\begin{array}{c}\text { WRIGHT'S } \\
\text { White Villa Grocery } \\
\text { CEDARVILLE, OHIO }\end{array}$ \\
VOGUE & SHOP \\
UNIVERSITY-STYLED CLOTHES FOR MEN \\
SPRINGFIE, OHIO
\end{tabular}


AUTOGRAPHS 
AUTOGRAPHS 


\section{AUTOGRAPHS}


AUTOGRAPHS 
AUTOGRAPHS 
AUTOGRAPHS 
AUTOGRAPHS 
AUTOGRAPHS 
AUTOGRAPHS 
AUTOGRAPHS 




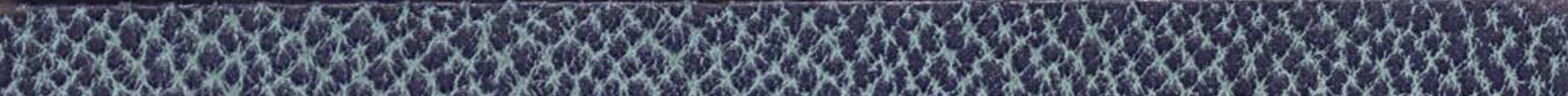

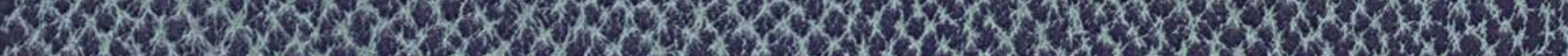

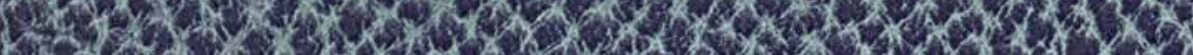

G.

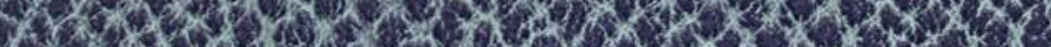

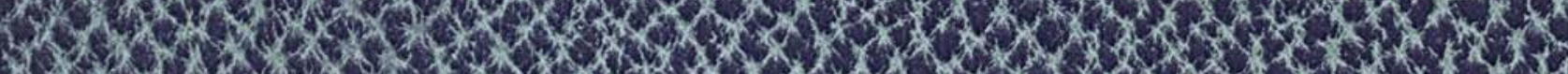

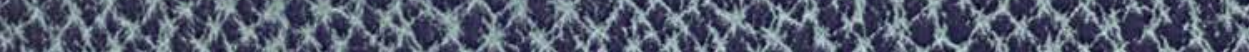

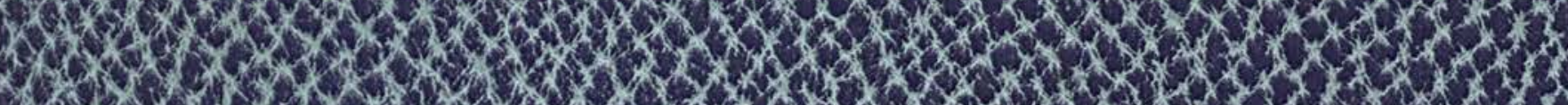

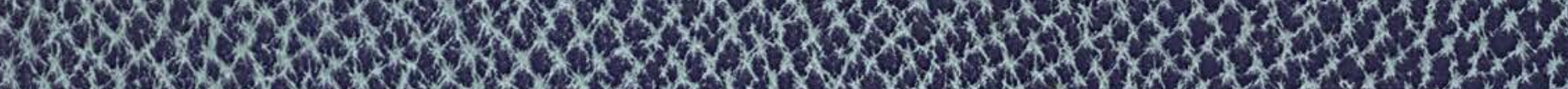

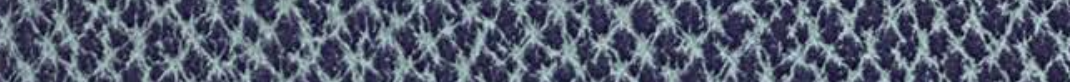

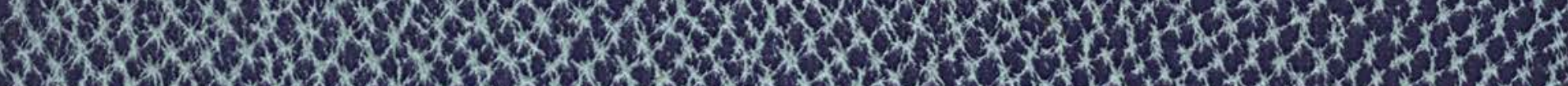

120 .

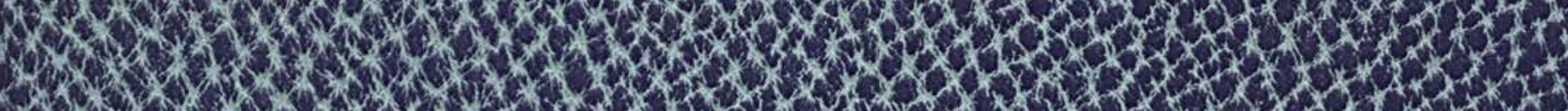

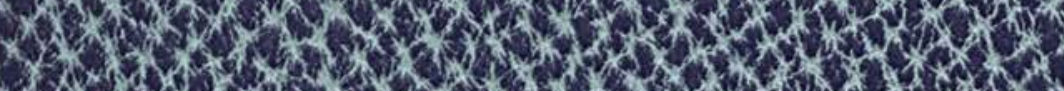

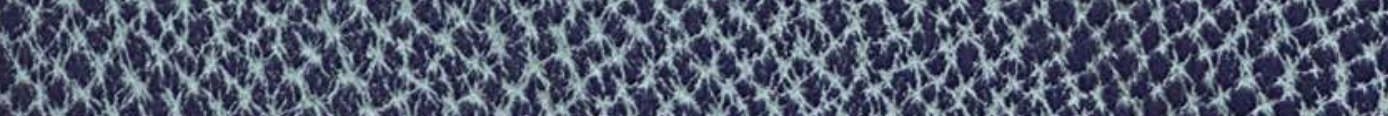

1.2.

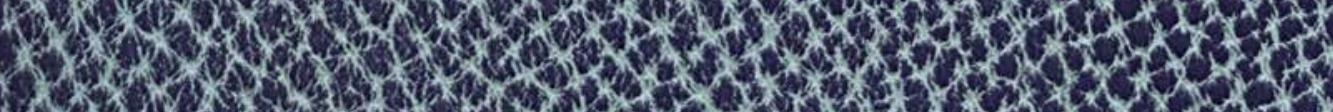

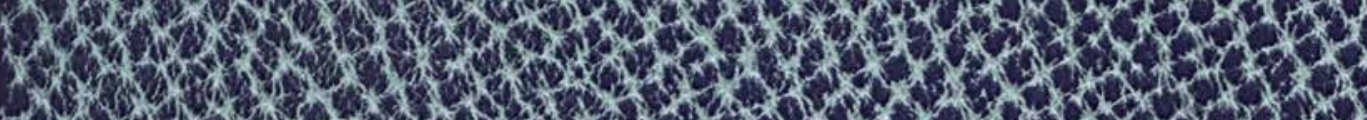

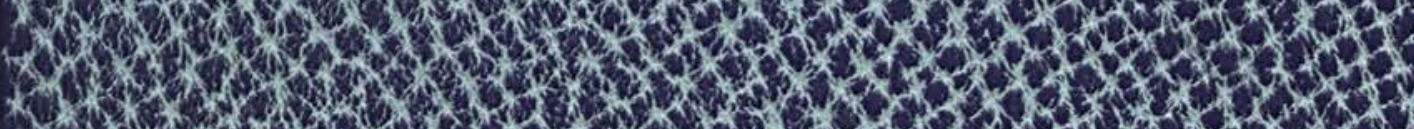

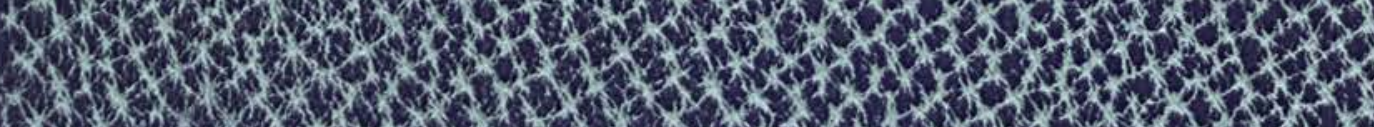

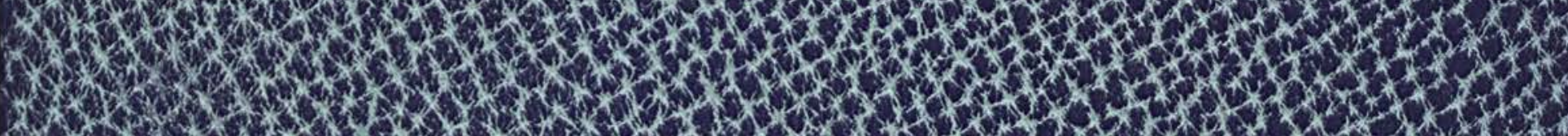

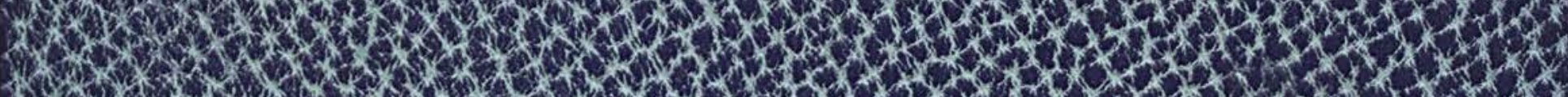

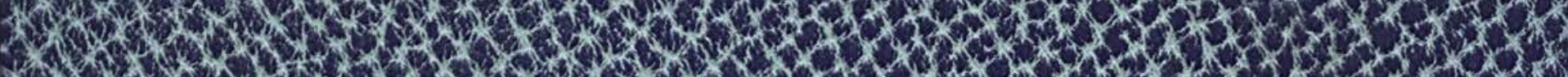

1.

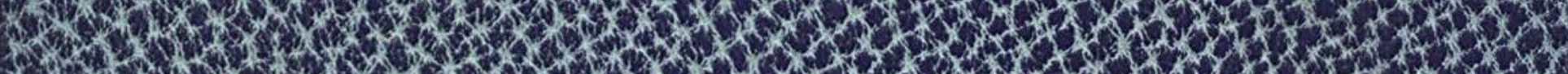

17.

1.

3.

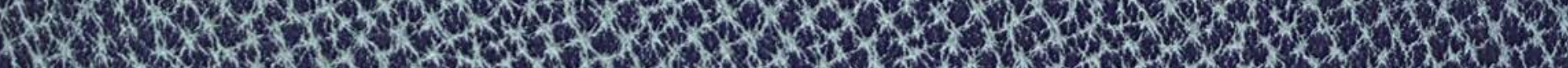

X.

1.2.

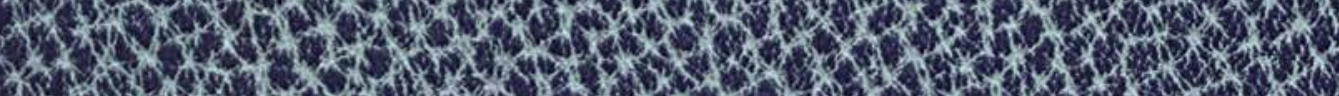

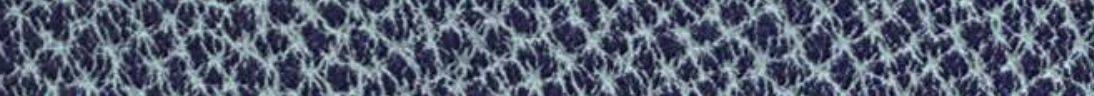

10

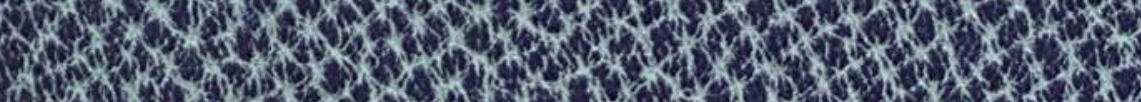

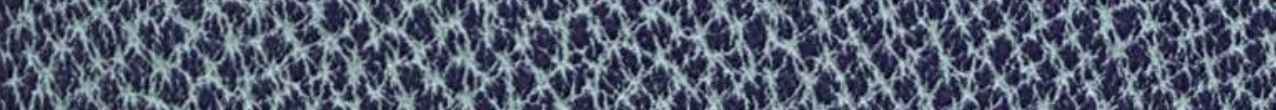

H.

(n)

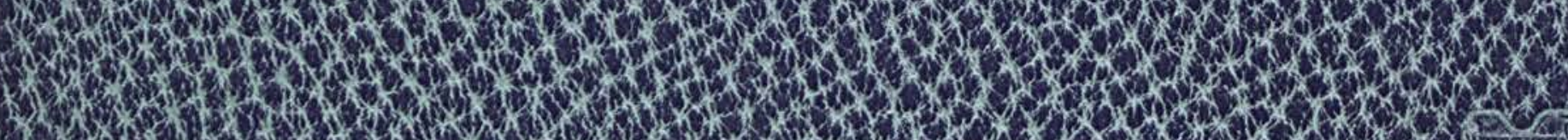

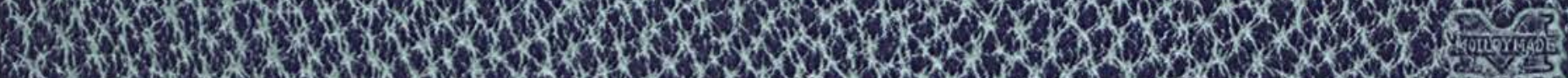

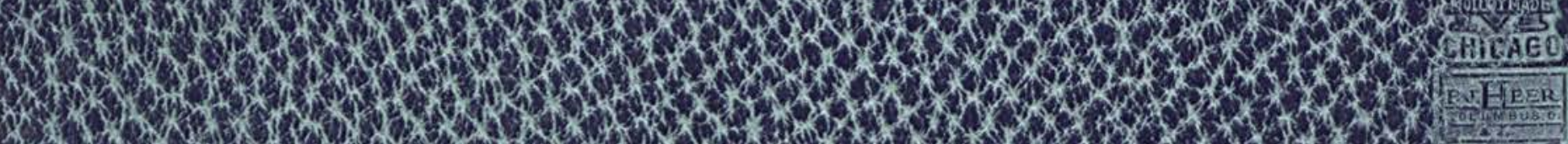

